OAK RIDGE

NATIONAL LABORATORY

MANAGED BY UT-BATTELLE

FOR THE DEPARTMENT OF ENERGY

\title{
Spatial Kinetics Calculations of MOX Fuelled Core: Variant 22
}

A. M. Pavlovichev

S. N. Bolshagin
A. A. Pinegin
L. K. Shishkov
D. L. Shishkov
B. E. Shumsky
Y. A. Styrin

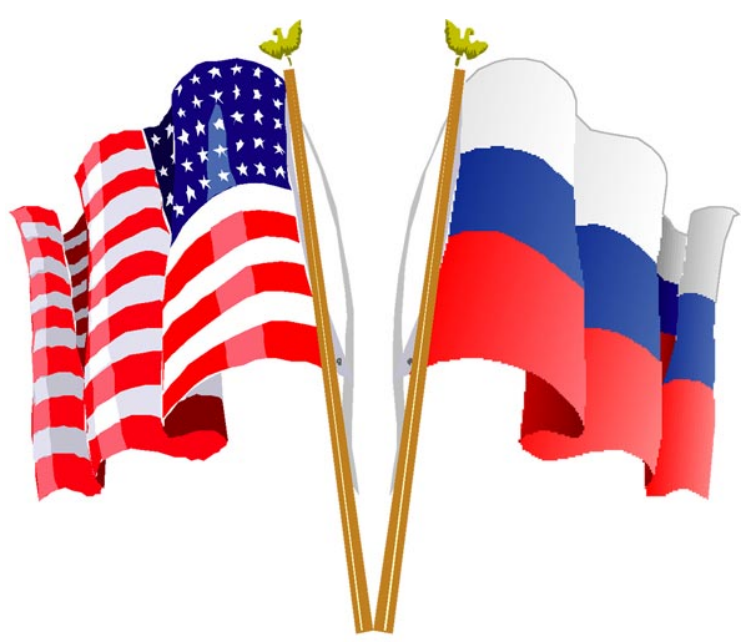

Fissile Materials Disposition Program

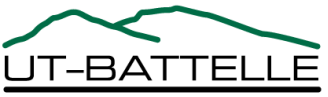




\section{DOCUMENT AVAILABILITY}

Reports produced after January 1, 1996, are generally available free via the U.S. Department of Energy (DOE) Information Bridge.

Web site http://www.osti.gov/bridge

Reports produced before January 1, 1996, may be purchased by members of the public from the following source.

National Technical Information Service

5285 Port Royal Road

Springfield, VA 22161

Telephone 703-605-6000 (1-800-553-6847)

TDD 703-487-4639

Fax 703-605-6900

E-mail info@ntis.fedworld.gov

Web site http://www.ntis.gov/support/ordernowabout.htm

Reports are available to DOE employees, DOE contractors, Energy Technology Data Exchange (ETDE) representatives, and International Nuclear Information System (INIS) representatives from the following source.

Office of Scientific and Technical Information

P.O. Box 62

Oak Ridge, TN 37831

Telephone 865-576-8401

Fax 865-576-5728

E-mail reports@adonis.osti.gov

Web site http://www.osti.gov/contact.html

This report was prepared as an account of work sponsored by an agency of the United States Government. Neither the United States Government nor any agency thereof, nor any of their employees, makes any warranty, express or implied, or assumes any legal liability or responsibility for the accuracy, completeness, or usefulness of any information, apparatus, product, or process disclosed, or represents that its use would not infringe privately owned rights. Reference herein to any specific commercial product, process, or service by trade name, trademark, manufacturer, or otherwise, does not necessarily constitute or imply its endorsement, recommendation, or favoring by the United States Government or any agency thereof. The views and opinions of authors expressed herein do not necessarily state or reflect those of the United States Government or any agency thereof. 
ORNL/SUB/99-B99398V-6

\title{
SPATIAL KINETICS CALCULATIONS OF MOX FUELLED CORE: VARIANT 22
}
A. M. Pavlovichev
S. N. Bolshagin
A. A. Pinegin
L. K. Shishkov
D. L. Shishkov
B. E. Shumsky
Y. A. Styrin

Date Published: December 2000

\author{
Prepared by \\ Russian Research Center "Kurchatov Institute" \\ Institute of Nuclear Reactors \\ under subcontract 85B-99398V \\ Funded by \\ Office of Fissile Materials Disposition \\ U.S. Department of Energy \\ Prepared for \\ Computational Physics and Engineering Division \\ OAK RIDGE NATIONAL LABORATORY \\ Oak Ridge, Tennessee 37831 \\ managed by \\ UT-BATTELLE, LLC \\ for the \\ U.S. DEPARTMENT OF ENERGY \\ under contract DE-AC05-00OR22725
}


Page Intentionally Blank 


\title{
Russian Research Center "Kurchatov Institute" Institute of Nuclear Reactors \\ VVER Division
}

Joint U.S. / Russian Project to Update, Verify and Validate Reactor Design/Safety Computer Codes Associated with Weapons-Grade Plutonium Disposition in WVR Reactors

\section{Spatial Kinetics Calculations of MOX Fuelled Core. Variant 22}

\author{
(Report)
}

General Order 85B-99398V. Work Release 02. P. 99-4a

Project Manager

A.M.Pavlovichev

Executed by

S.N.Bolshagin
A.A.Pinegin
L.K.Shishkov
D.L.Shishkov
B.E.Shumsky
Y.A.Styrin 
Russian Research Center "Kurchatov Institute" Spatial Kinetics Calculations of MOX Fuelled Core. Variant 22

\section{ACRONYMS}

\begin{tabular}{|c|c|c|}
\hline Russian & & $\begin{array}{l}\text { West } \\
\text { Equivalent }\end{array}$ \\
\hline $\mathrm{AZ}$ & emergency (accident) protection & AP \\
\hline AZ-1 & $\begin{array}{l}\text { state with all the control rods fully inserted except of } \\
\text { one the most effective stuck in upper position }\end{array}$ & AP-1 \\
\hline $\mathrm{BOC}$ & Beginning Of fuel Cycle & $\mathrm{BOC}$ \\
\hline BPR & Burnable Poison Rod & $\mathrm{BPR}$ \\
\hline BRU-A & Atmospheric Steam Dump (PG Relief Valves) & \\
\hline DNB & $\begin{array}{l}\text { Departure from Nucleate Boiling ( passing of Critical } \\
\text { Heat Flux) }\end{array}$ & DNB \\
\hline DNBR & Departure from Nucleate Boiling Ratio & DNBR \\
\hline DTC & Doppler Temperature Coefficient & DTC \\
\hline EFPD & Effective Full Power Day & EFPD \\
\hline $\mathrm{EOC}$ & End Of fuel Cycle & EOC \\
\hline FP & Fission Products & $\mathrm{FP}$ \\
\hline $\mathrm{KI}$ & Kurchatov Institute & $\mathrm{KI}$ \\
\hline LTA & Lead Test Assembly & LTA \\
\hline LWR & Light Water Reactor & LWR \\
\hline $\mathrm{MCL}$ & Minimum Controllable reactor power Level & MCL \\
\hline $\mathrm{MDC}$ & Moderator Density Coefficient & $\mathrm{MDC}$ \\
\hline MOX & Mixed Oxide (uranium-plutonium fuel) & MOX \\
\hline MTC & Moderator Temperature Coefficient & MTC \\
\hline NPP & Nuclear Power Plant & NPP \\
\hline OR & Regulatory Body (Control Rod) & $\mathrm{CR}$ \\
\hline $\mathrm{PG}$ & Steam Generator & $\mathrm{SG}$ \\
\hline PWR & Pressurized-Water Reactor & PWR \\
\hline $\mathrm{RCT}$ & Repeat Criticality Temperature & $\mathrm{RCT}$ \\
\hline SUZ & Reactor Control and Protection System & RPS \\
\hline TVS, FA & Fuel Assembly & FA \\
\hline UOX, LEU & Uranium Oxide Fuel (Light Enrichment Uranium) & UOX, LEU \\
\hline VVER & Russian water-water reactor & VVER \\
\hline
\end{tabular}


Russian Research Center "Kurchatov Institute" Spatial Kinetics Calculations of MOX Fuelled Core. Variant 22

\section{Executive Summary}

In this document the reactor-kinetics benchmarks are presented for $30 \% \mathrm{MOX}$ fuelled core of VVER-1000. Both UOX and MOX cores are calculated for three types of accidents:

- control rod ejection,

- overcooling of the reactor core caused by steam line rupture,

- boron dilution of coolant. 
Russian Research Center "Kurchatov Institute"

Spatial Kinetics Calculations of MOX Fuelled Core. Variant 22

\section{CONTENTS}

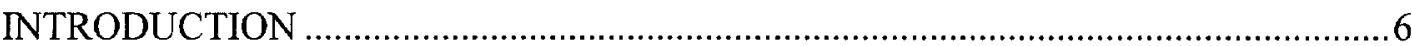

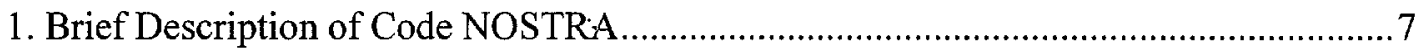

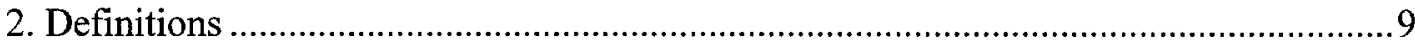

3. Equilibrium Fuel Cycle with 30\% MOX Loaded Core (Variant 21)............................. 14

4. Central Control Rod Ejection from the VVER-1000 Core...........................................38

5. Core Cooling in Case of Steam Line Rupture ..............................................................48

6. The Boron Dilution of Coolant in a Part of the VVER-1000 Core ...............................57

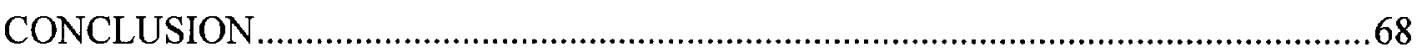

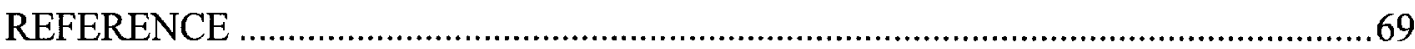

Table 3-1. Composition of Weapons Grade Plutonium ...............................................15

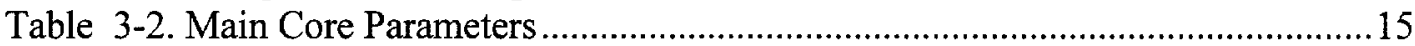

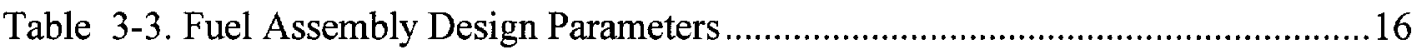

Table 3-4. Uranium Fuel Pin Design Parameters ............................................................. 17

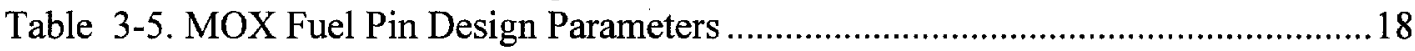

Table 3-6. Discrete Burnable Poison Pin Design Parameters.......................................... 19

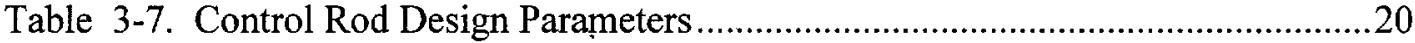

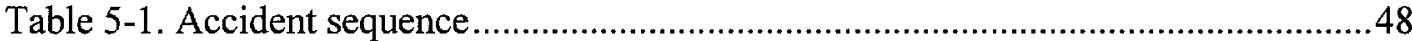

Table 5-2. Variation of Core Parameters in the Accident with Steam Line Rupture and

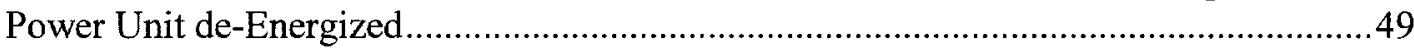

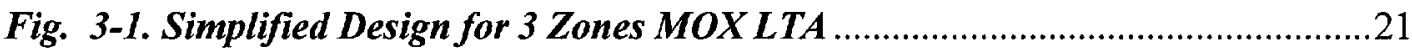

Fig. 3-2. Simplified Design for VVER-1000 Fuel Assembly. Type A .........................22

Fig. 3-3. Simplified Design for VVER-1000 Fuel Assembly. Type B, Ba and Bb .......23

Fig. 3-4. Simplified Design for VVER-1000 Fuel Assembly. Type C.........................24

Fig. 3-5. Equilibrium Loading Pattern for Base Uranium Core with Boron BPRs.....25

Fig. 3-6. Uranium Zone. Assembly Burnup, Relative Power ..................................26

Fig. 3-7. Equilibrium Loading Pattern for MOX Fuelled Core with $54 \mathrm{MOX}$ Fuel

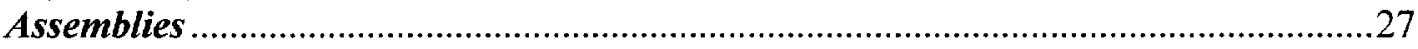

Fig. 3-8. MOX Zone. Assembly Burnup, Relative Power. ........................................28

Fig. 3-9. Control Rods Grouping and Positions of In-core Self-Powered Detectors.....29

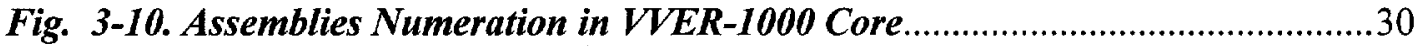

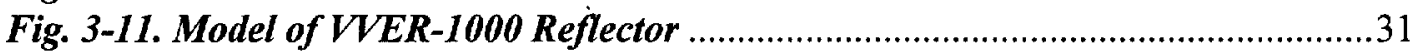

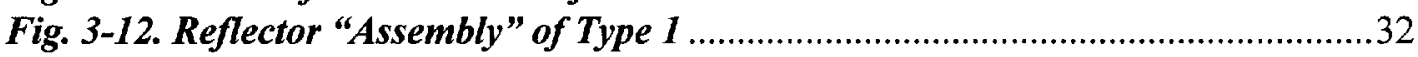

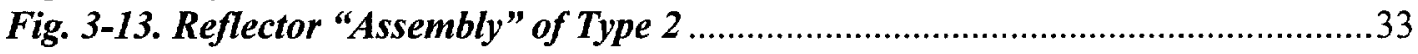

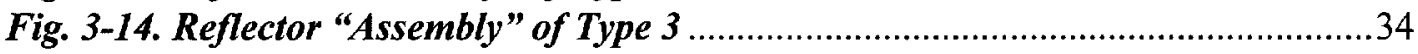

Fig.3-17. Core Design. Material Contents (Vol\%) in Axial Direction ........................37

Fig. 4-1. Uranium zone. Assembly burnup, relative power and temperature drop for

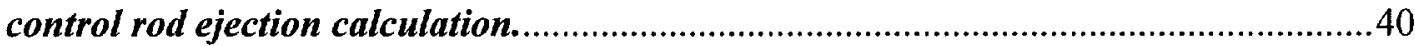

Fig. 4-2. MOX zone. Assembly burnup, relative power and temperature drop for

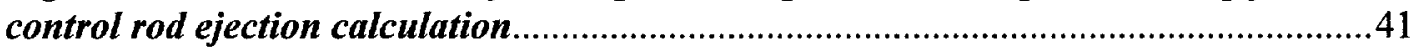

Fig. 4-3. Reactivity. Central Control Rod Ejection ....................................................42

Fig. 4-4. Neutron Power. Central Control Rod Ejection ...........................................43 
Russian Research Center "Kurchatov Institute"

Spatial Kinetics Calculations of MOX Fuelled Core. Variant 22

Fig. 4-5. Maximal Neutron Linear Power. Central Control Rod Ejection 44

Fig. 4-6. Maximal Fuel Temperature. Central Control Rod Ejection ..........................45

Fig. 4-7. Minimal DNBR. Central Control Rod Ejection ..........................................46

Fig. 4-8. Maximal Fuel Enthalpy. Central Control Rod Ejection ................................47

Fig. 5-1. Inlet Temperature in Different Parts of the Core. Partial Core Overcooling.50

Fig. 5-2. Reactivity. Partial Core Overcooling …......................................................... 51

Fig. 5-3. Neutron Power. Partial Core Overcooling .................................................5 52

Fig. 5-4. Maximal Neutron Linear Power. Partial Core Overcooling .........................53

Fig. 5-5. Maximal Fuel Temperature. Partial Core Overcooling ….............................5 54

Fig. 5-6. Minimal DNBR. Partial Core Overcooling …............................................55

Fig. 5-7. Assembly Power. Partial Core Overcooling. MOX + LEU ..........................56

Fig. 6-1. Numbers of Fuel Assemblies in the Quarter of the Core ...............................59

Fig. 6-2. Concentration of Boron Acid. Loop Put into Operation \& Boron Dilution ... 60

Fig. 6-3. Reactivity. Loop Put into Operation \& Boron Dilution ..................................61

Fig. 6-4. Neutron Power. Loop Put into Operation \& Boron Dilution .........................62

Fig. 6-5. Maximal Neutron Power. Loop Put into Operation \& Boron Dilution ..........63

Fig. 6-6. Maximal Fuel Temperature. Loop Put into Operation \& Boron Dilution ..... 64

Fig. 6-7. Minimal DNBR. Loop Put into Operation \& Boron Dilution ........................65

Fig. 6-8. Maximal Fuel Enthalpy. Loop Put into Operation \& Boron Dilution ...........66 66

Fig. 6-9. Power of Assembly N 4. Loop Put into Operation \& Boron Dilution .............67 


\section{Russian Research Center "Kurchatov Institute" \\ Spatial Kinetics Calculations of MOX Fuelled Core. Variant 22}

\section{INTRODUCTION}

This work is a part of Joint U.S. / Russian Project with Weapons-Grade Plutonium Disposition in VVER Reactors and presents the results of spatial kinetics calculational benchmarks.

The examinations were carried out with the following purposes:

- to verify one of spatial neutronic kinetics model elaborated in KI,

- to understand sensibility of the model to neutronics difference of UOX and MOX cores,

- to compare in future point and spatial kinetics models (on the base of a set of selected accidents) in view of eventual creation of RELAP option with 3D kinetics.

The document contains input data and results of model operation of three emergency dynamic processes in the VVER-1000 core:

- Central control rod ejection by pressure drop caused by destroying of the moving mechanism cover.

- Overcooling of the reactor core caused by steam line rupture and non-closure of steam generator stop valve.

- The boron dilution of coolant in part of the VVER-1000 core caused by penetration of the distillate slug into the core at start up of non-working loop.

These accidents have been applied to

- Uranium reference core that is the so-called Advanced VVER-1000 core with Zirconium fuel pins claddings and guide tubes. A number of assemblies contained 18 boron BPRs while first year operating.

- MOX core with about $30 \%$ MOX fuel.

At a solving it was supposed that MOX-fuel thermophysical characteristics are identical to uranium fuel ones.

The calculations were carried out with the help of the program NOSTRA / $1 /$, simulating VVER dynamics that is briefly described in Chapter1.

Chapter 3 contains the description of reference Uranium and MOX cores that are used in calculations. The neutronics calculations of MOX core with about $30 \% \mathrm{MOX}$ fuel are named "Variant 21 ".

Chapters 4-6 contain the calculational results of three above mentioned benchmark accidents that compose in a whole the "Variant 22 ". 
Russian Research Center "Kurchatov Institute"

Spatial Kinetics Calculations of MOX Fuelled Core. Variant 22

\section{Brief Description of Code NOSTRA}

Code NOSTRA have been developed for safety parameters investigations of nuclear power plants (NPP) with reactors of VVER type. Code is intended for computational analysis of transient and accidental processes that may include arising of core multiplying properties ingomogeneity, for example failures of steam generator operation due to non-complete mixing of coolant in pressure chamber, "shooting" of alone cluster etc.

Code NOSTRA allows to obtain the time-dependent three-dimensional neutron and temperature distributions in core. Code is capable to model the variations of NPP equipment operation regime for known time-dependencies of flow rate, pressure and temperature of coolant at the core inlet and for known strategy of control rods movement.

Code allows to compute the transient and accidental regimes caused by the following reasons:

- failures of main circulation pumps;

- variation in steam generator load;

- failures in feed water system;

- rupture of pipelines in the 2-nd circuit;

- rupture of pipelines in feed water system;

- rupture of pipelines in auxiliary system of the 1-st circuit;

- action of reactor power control system;

- violation in action of reactor power control system, e.g. self-movement of control rod, sticking of cluster during operation etc.;

- throwing out the cluster;

- any combination of these reasons.

Code is capable to perform the operational computations for NPP with reactors VVER-440, VVER-1000 and design computations for advanced NPPs.

Neutronics processes are simulated on the basis of certified code BIPR-7 [2] methodology that was generalized on non-stationary equations with 6 groups of delayed neutron predecessors and non zero life-time of prompt neutrons. Code BIPR-7 considers 3-dimensional 1.5-group diffusion model of neutron transport. Diffusion equations are solved by the 'coarse-mesh' method with coefficients obtained with using of nodal algorithm. Asymptotic and transient functions of each node are utilized as modes. Additional balances are formed at the boundaries of considered prisms. Algorithm takes into account the discontinuity of diffusion properties on boundaries of nodes. For solving of the algebraic equations the non-linear iterative procedure is used that permits to reduce the dimensionality of the problem.

Neutronics characteristics of nodes are approximated by polynomials depending on the sort of fuel, fuel burnup, concentrations of boron and xenon, temperature distribution and state of coolant. The applicability of neutron algorithms is restricted to the steam content of no more than $10 \%$.

Code solves the burnup equations and permit to analyse transients in any time of reactor operation. Model of residual heat generation takes into account the fuel burnup and is based on US Standard ANS-5.1. 


\section{Russian Research Center "Kurchatov Institute" Spatial Kinetics Calculations of MOX Fuelled Core. Variant 22}

Fuel and coolant temperature, concentrations of delayed neutrons predecessors are defined as average values for considered prisms formed in core space discretization as in codes of BIPR type.

Thermophysical model of the fuel elements considers the cladding, gas-gap and three fuel layers. Equations of heat and mass transfer are solved by explicit-implicit methods. Choice of method depends on the value of time step. Hydraulic computation is carried out for each assembly allowing to consider the situations with increased hydraulic resistance of some assemblies.

Code NOSTRA is provided by special system for graphic and tabular presentation of output data. Particularly, there is a capability to print two- and threedimensional histograms of temperature and neutron fields. Code NOSTRA is forming the files of three-dimensional neutron fields for each step of time. It is possible to perform the time scanning of reactor parameters as animated cartoon.

Calculational subroutines are written on FORTRAN-language, service subroutines - on PASCAL-language. Code NOSTRA is operated on computers of IBM PC type. 
Russian Research Center "Kurchatov Institute"

Spatial Kinetics Calculations of MOX Fuelled Core. Variant 22

\section{Definitions}

\begin{tabular}{|c|c|c|c|}
\hline Parameter & Abbreviation & Units & Remarks \\
\hline Calculational system & $\mathrm{CS}$ & & Multi-assembly or core \\
\hline CS symmetry sector & Sim & & $\begin{array}{l}30 \text { for } 30^{\circ}, 60 \text { for } 60^{\circ}, \\
120 \text { for } 120^{\circ}, 360 \text { for full CS. }\end{array}$ \\
\hline Reactivity of CS & $\mathrm{RO}$ & $\mathrm{pcm}$ & $\mathrm{RO}=(\mathrm{Keff}-1) / \mathrm{Keff} * 1 . \mathrm{E} 5$ \\
\hline Calculational volume & Vij & & $\begin{array}{l}\text { Axial fraction } j \text { of assembly number } i \text {. } \\
\text { In VVER- } 1000 \text { calculations, } 10-30 \text { axial } \\
\text { fractions of equal volume are usually used. }\end{array}$ \\
\hline Effective multiplication factor of CS & Keff & & \\
\hline Multiplication factor of CS & Ko & & $\begin{array}{l}\text { Relation of neutron generation to neutron } \\
\text { absorption. } \\
\text { For core calculations Ko values are attributed to } V_{i j}\end{array}$ \\
\hline 3-D power distribution in core & $\mathrm{q}_{\mathrm{ii}}$ & & Power in Vij normalised by average Vij power \\
\hline Volume power peaking factor & $\mathrm{Kv}$ & & Maximum in $\mathrm{q}_{\mathrm{ij}}$ values \\
\hline $\begin{array}{l}\text { Radial position of volume power peaking } \\
\text { factor }\end{array}$ & $\mathrm{N}(\mathrm{Kv})$ or $\mathrm{N}_{\mathrm{K}}$ & & $\begin{array}{l}\text { Number of assembly in calculational core } \\
\text { sector where } \mathrm{Kv} \text { is realised }\end{array}$ \\
\hline Axial position of volume power peaking factor & $\mathrm{M}(\mathrm{Kv})$ or $\mathrm{N}_{\mathrm{Z}}$ & & Number of axial level where $\mathrm{Kv}$ is realised \\
\hline 3-D burnup distribution in core & BUij & $\begin{array}{l}\mathrm{MWd} / \mathrm{kg} \\
\text { or } \mathrm{GWd} / \mathrm{t}\end{array}$ & Burnup in Vij. \\
\hline 2-D power distribution in core & $\mathrm{q}_{\mathrm{i}}$ & & $\begin{array}{l}\text { Assembly powers normalised by average } \\
\text { assembly power in core. }\end{array}$ \\
\hline Radial power peaking factor & $\mathrm{Kq}$ & & Maximum in qi values \\
\hline $\begin{array}{l}\text { Radial position of radial power peaking } \\
\text { factor }\end{array}$ & $\mathrm{N}(\mathrm{Kq})$ or $\mathrm{N}_{\mathrm{K}}$ & & $\begin{array}{l}\text { Number of assembly in calculational core } \\
\text { sector where } \mathrm{Kq} \text { is realised }\end{array}$ \\
\hline Pin linear power & Q1 & $\mathrm{W} / \mathrm{cm}$ & $\begin{array}{l}\text { Pin power for } 1 \mathrm{~cm} \text { of an axial calculational } \\
\text { fraction }\end{array}$ \\
\hline Moment during fuel irradiation & $\mathrm{T}$ & EFPD & \\
\hline
\end{tabular}


Russian Research Center "Kurchatov Institute"

Spatial Kinetics Calculations of MOX Fuelled Core. Variant 22

\begin{tabular}{|c|c|c|c|}
\hline 2-D burnup distribution in core & $\mathrm{BUi}$ & $\mathrm{MWd} / \mathrm{kg}$ & Average-assembly burnup distribution in core. \\
\hline Average burnup in Uranium assemblies & $\mathrm{B}_{\mathrm{U}}$ & $\begin{array}{l}\mathrm{MWd} / \mathrm{kg} \\
\text { or } \mathrm{GWd} / \mathrm{t}\end{array}$ & \\
\hline Average burnup in MOX assemblies & $\mathrm{B}_{\mathrm{MOX}}$ & $\begin{array}{l}\mathrm{MWd} / \mathrm{kg} \\
\text { or } \mathrm{GWd} / \mathrm{t}\end{array}$ & \\
\hline $\begin{array}{l}\text { Average Boron acid }\left(\mathrm{H}_{3} \mathrm{BO}_{3}\right) \\
\text { concentration }{ }^{\mathrm{a}} \text { in coolant }\end{array}$ & $\begin{array}{c}\mathrm{Cb} \text { or } \\
\mathrm{C}_{\mathrm{H} 3 \mathrm{BO} 3}\end{array}$ & $\begin{array}{l}\mathrm{ppm} \\
\text { or } \mathrm{g} / \mathrm{kg}\end{array}$ & $\begin{array}{l}\mathrm{H}_{3} \mathrm{BO}_{3} \text { fraction in coolant (unit "ppm" means } \\
\text { mg of boron acid in } 1 \mathrm{Kg} \text { of } \mathrm{H}_{2} \mathrm{O} \text { ) }\end{array}$ \\
\hline Critical boron acid concentration in coolant & $\mathrm{Cb}^{\text {crit }}$ & $\begin{array}{l}\mathrm{ppm} \\
\text { or } \mathrm{g} / \mathrm{kg}\end{array}$ & $\mathrm{Cb}\left(\mathrm{C}_{\mathrm{H} 3 \mathrm{BO} 3}\right)$ value ensuring $\mathrm{Keff}=1$ \\
\hline 2-D power distribution in CS & $\mathrm{q}_{\mathrm{k}}-\mathrm{CS}$ & & $\begin{array}{l}\text { Power of fuel pins normalised by average fuel } \\
\text { pin power in CS. }\end{array}$ \\
\hline Peaking factor of 2-D power distribution in CS & $\mathrm{K}_{\mathrm{FA}}-\mathrm{CS}$ & & Maximum in $\mathrm{q}_{\mathrm{k}}-\mathrm{CS}$ values \\
\hline 2-D power distribution in assembly & $\mathrm{q}_{\mathrm{k}}$ & & $\begin{array}{l}\text { Power of fuel pins normalised by average fuel } \\
\text { pin power in assembly (in some axial fraction). }\end{array}$ \\
\hline $\begin{array}{l}\text { 3-D power distribution in axial volumes } \\
\text { of fuel pins in core }\end{array}$ & $\mathrm{q}_{\mathrm{ijk}}$ & & $\begin{array}{l}\text { Power of axial volumes of fuel pins normalised by } \\
\text { average power in such volumes over a whole core }\end{array}$ \\
\hline Pin power peaking factor in assembly & Kki & & $\begin{array}{l}\text { Among } q_{k} \text { values for an assembly number } i \text { for a } \\
\text { fraction number } j \text { where maximum } q_{i j} \text { for this } \\
\text { assembly is realised. }\end{array}$ \\
\hline Radial pin power peaking factor & $\mathrm{Kr}$ & . & $\max (q i * K k i)$ \\
\hline $\begin{array}{l}\begin{array}{l}\text { Radial position of radial pin power } \\
\text { peaking factor }\end{array} \\
\text { peang }\end{array}$ & $\mathrm{N}(\mathrm{Kr})$ or $\mathrm{N}_{\mathrm{K}}$ & & $\begin{array}{l}\text { Number of assembly in calculational core } \\
\text { sector where } \mathrm{Kr} \text { is realised }\end{array}$ \\
\hline 2-D power peaking factor in assembly & $\begin{array}{c}\mathrm{K}_{\mathrm{FA}} \\
\text { (notation Kk or } \\
\mathrm{Kk}_{\max } \text { is also used) }\end{array}$ & & $\begin{array}{c}\text { Maximum relative power of fuel pins } \\
\text { (maximum in } q_{k} \text { values) }\end{array}$ \\
\hline
\end{tabular}

\footnotetext{
a Boron acid concentration divided by the coefficient 5.72 means natural boron (nat B) concentration. In VVER-1000 calculations the term of boron acid
} concentration is widely used. Below, $\mathrm{Cb}$ means boron acid concentration if there is no special indication. 
Russian Research Center "Kurchatov Institute"

Spatial Kinetics Calculations of MOX Fuelled Core. Variant 22

\begin{tabular}{|c|c|c|c|}
\hline $\begin{array}{l}\text { Axial power peaking factor in assembly } \\
\text { or in fuel pin }\end{array}$ & $\mathrm{Kz}$ & & $\begin{array}{l}\text { Maximum relative power of axial volume in } \\
\text { assembly or in fuel pin normalised by average } \\
\text { power in such volumes (in assembly or in fuel pin) }\end{array}$ \\
\hline Total power peaking factor & Ko or $\mathrm{K}_{\mathrm{o} \text {-total }}$ & & $\left.\underset{\mathrm{max}}{\operatorname{ma\mathrm {ij}}} \mathrm{q}_{\mathrm{ij}} \mathrm{Kki}\right)=\mathrm{Kr} * \mathrm{Kz}$ \\
\hline $\begin{array}{l}\text { Radial position of total power peaking } \\
\text { factor }\end{array}$ & $\begin{array}{l}\mathrm{N}\left(\mathrm{K}_{\mathrm{o} \text {-total }}\right) \text { or } \\
\mathrm{N}_{\mathrm{K}} \\
\end{array}$ & & $\begin{array}{l}\text { Number of assembly in calculational core } \\
\text { sector where } \mathrm{K}_{\text {o-total }} \text { is realised }\end{array}$ \\
\hline $\begin{array}{l}\text { Axial position of total power peaking } \\
\text { factor }\end{array}$ & $\begin{array}{l}\mathrm{M}\left(\mathrm{K}_{\mathrm{o} \text {-total }}\right) \text { or } \\
\mathrm{N}_{\mathrm{Z}}\end{array}$ & & Number of axial level where $\mathrm{K}_{\mathrm{o} \text {-total }}$ is realised \\
\hline Engineering factor & $\mathrm{K}_{\text {eng }}$ & & $\begin{array}{l}\text { Coefficient taking account of uncertainty of a } \\
\text { hot point (maximum fuel pin local power) } \\
\text { calculations }\end{array}$ \\
\hline 2-D burnup distribution in assembly & BUk & $\begin{array}{l}\mathrm{MWd} / \mathrm{kg} \\
\text { or } \mathrm{GWd} / \mathrm{t}\end{array}$ & Average-pin burnup distribution in CS. \\
\hline 1-D burnup distribution in fuel pin & BUpin & & $\begin{array}{l}\text { Burnup distribution in concentric zones of } \\
\text { equal volume in fuel pin, normalised by average } \\
\text { zone burnup. }\end{array}$ \\
\hline 1-D power distribution in fuel pin & $\mathrm{q}_{\mathrm{pin}}$ & & $\begin{array}{l}\text { Power distribution in concentric zones of equal } \\
\text { volume in fuel pin, normalised by average zone } \\
\text { power. }\end{array}$ \\
\hline Regulation bank position & $\mathrm{H}_{\mathrm{reg}}$ & $\mathrm{cm}$ & Distance from core bottom till rods lower edge \\
\hline Control rods worth (in core) & $(\mathrm{RO})_{\mathrm{AP}-1}$ & ppm & $\begin{array}{l}\text { Effect of control rods insertion in core } \\
\text { supposing the most effective single CR stuck in } \\
\text { upper position. } \\
\text { It is defined as a reactivity difference in two } \\
\text { states: } \\
\text { (RO) }{ }_{A P-1}=\mathrm{RO} 1-\mathrm{RO} 2 \text {. } \\
\text { The second state differs from the first one only } \\
\text { by additional CRs inserted in core. All the other }\end{array}$ \\
\hline
\end{tabular}


Russian Research Center "Kurchatov Institute"

Spatial Kinetics Calculations of MOX Fuelled Core. Variant 22

\begin{tabular}{|c|c|c|c|}
\hline & & & $\begin{array}{l}\text { parameters correspond to the first state: } \mathrm{Cb} \text { (that is } \\
\text { equal to } \mathrm{Cb} \text { crit for the first state), temperature and } \\
\mathrm{FP} \text { distribution in core. }\end{array}$ \\
\hline Repeat Criticality Temperature & $\mathrm{RCT}$ & ${ }^{\circ} \mathrm{C}$ & $\begin{array}{l}\text { Temperature that ensures a secondary critical state } \\
\text { during core cooling in EOC in such conditions: all } \\
\text { control rods inserted in core except one the most } \\
\text { effective, zero boron concentration, equilibrium } \\
\text { xenon concentration corresponding to reactor } \\
\text { power before its shut-down. }\end{array}$ \\
\hline Moderator temperature coefficient (in core) & MTC & $\mathrm{pcm} /{ }^{\circ} \mathrm{C}$ & \\
\hline Moderator density coefficient (in core) & $\mathrm{MDC}$ & $\mathrm{pcm} / \mathrm{g} / \mathrm{cc}$ & \\
\hline $\begin{array}{l}\text { Doppler temperature coefficient (in core) } \\
\end{array}$ & DTC & $\mathrm{pcm} /{ }^{\circ} \mathrm{C}$ & $\begin{array}{l}\text { Calculated supposing average fuel temperature } \\
\text { changing of } 1^{\circ} \mathrm{C}^{\circ}\end{array}$ \\
\hline $\begin{array}{l}\text { Doppler isotermic temperature coefficient } \\
\text { (in core) }\end{array}$ & DTC $^{*}$ & $\mathrm{pcm} /{ }^{\circ} \mathrm{C}$ & $\begin{array}{l}\text { Calculated supposing local fuel temperature } \\
\text { changing of } 1^{\circ} \mathrm{C}\end{array}$ \\
\hline Doppler power coefficient (in core) & $\mathrm{DPC}$ & $\mathrm{pcm} / \mathrm{MW}$ & \\
\hline Boron reactivity coefficient (in core) & DRO/DCB & $\mathrm{pcm} / \mathrm{ppm}$ & \\
\hline Effective fraction of delayed neutrons & $\beta$ eff or $\beta_{\text {ef. }}$ & ppm & General characteristic of infinite grid or core \\
\hline Lifetime of prompt neutrons & $l_{m}$ or $l_{i m}$ & $\mathbf{s}$ & General characteristic of infinite grid or core \\
\hline Reactor thermal power & $\mathrm{W}$ & MW & \\
\hline Specific reactor thermal power in CS & Wv & KW/litre & Reactor thermal power in CS volume unit \\
\hline Nominal reactor thermal power & Wnom & MW & Equal to $3000 \mathrm{MW}$ for VVER-1000 \\
\hline $\begin{array}{l}\text { Minimum controllable level of reactor } \\
\text { power }\end{array}$ & MCL & MW & $\begin{array}{l}\text { In calculations corresponds to Zero Power and } \\
\text { uniform temperature } 280^{\circ} \mathrm{C} \text { in core. }\end{array}$ \\
\hline Core coolant flow rate & $\mathrm{G}$ & $\mathrm{m}^{3} / \mathrm{h}$ & \\
\hline Average entry core temperature & $t_{\text {entry }}$ & ${ }^{\circ} \mathrm{C}$ or $\mathrm{K}$ & \\
\hline Average outer core temperature & $t_{\text {out }}$ & ${ }^{\circ} \mathrm{C}$ or $\mathrm{K}$ & \\
\hline $\begin{array}{l}\text { Average coolant-moderator temperature in } \\
\text { CS }\end{array}$ & $t_{\text {mod }}$ & ${ }^{\circ} \mathrm{C}$ or $\mathrm{K}$ & \\
\hline
\end{tabular}


Russian Research Center "Kurchatov Institute"

Spatial Kinetics Calculations of MOX Fuelled Core. Variant 22

\begin{tabular}{|c|c|c|c|}
\hline $\begin{array}{l}\text { Average Coolant-moderator density in } \\
\mathrm{CS}\end{array}$ & $\gamma_{\bmod }$ & $\mathrm{g} / \mathrm{cm}^{3}$ & \\
\hline Fuel temperature & $t_{\text {fuel }}$ & $\mathrm{K}$ & \\
\hline $\begin{array}{l}\text { Average temperature of other } \mathrm{CS} \\
\text { components }\end{array}$ & $t_{\text {con }}$ & ${ }^{\circ} \mathrm{C}$ or $\mathrm{K}$ & \\
\hline Fuel pin cladding temperature & $t_{\text {clad }}$ & ${ }^{\circ} \mathrm{C}$ or $\mathrm{K}$ & \\
\hline $\begin{array}{l}\text { Xenon-135 concentration distribution in } \\
\text { core }\end{array}$ & $\mathrm{Xe}$ & $10^{24} / \mathrm{cc}$ & $\begin{array}{l}\text { For } 1 \mathrm{cc} \text { in fuel. } \\
\mathrm{Xe}=0 \rightarrow \text { xenon is absent; } \mathrm{Xe}=1 \rightarrow \mathrm{Xe}=\mathrm{Xe} \text { eq }(\mathrm{W}) \text {. }\end{array}$ \\
\hline $\begin{array}{l}\text { Equilibrium Xenon-135 concentration } \\
\text { distribution in core }\end{array}$ & Xe eq $(W)$ & $10^{24} / \mathrm{cc}$ & $\begin{array}{l}\text { Concentration formed during long working with } \\
\text { W power, regulating bank in nominal position }\end{array}$ \\
\hline $\begin{array}{c}\text { Sm-149 concentration distribution in core } \\
.\end{array}$ & Sm & $10^{24} / \mathrm{cc}$ & $\begin{array}{l}\text { For } 1 \text { cc in fuel. } \\
\qquad \mathrm{Sm}=0 \rightarrow \text { samarium is absent; } \mathrm{Sm}=1 \rightarrow \mathrm{Sm}=\mathrm{Sm} \text { eq, } \\
\mathrm{Sm}=3 \rightarrow \text { full decay of } \mathrm{Pm}-149 \text { into } \mathrm{Sm}-149 \text { is simulated } \\
\text { in BOC. }\end{array}$ \\
\hline $\begin{array}{ll}\begin{array}{l}\text { Equilibrium Sm-149 concentration } \\
\text { distribution in core }\end{array} & \\
\end{array}$ & Sm eq & $10^{24} / \mathrm{cc}$ & $\begin{array}{l}\text { Concentration formed during long working, } \\
\text { regulating bank in nominal position }\end{array}$ \\
\hline $\begin{array}{l}\text { Samarium- } 149 \text { concentration distribution, all } \\
\text { Prometium-149 decayed in Sm }\end{array}$ & $\mathrm{Smh}$ & $10^{24} / \mathrm{cc}$ & \\
\hline Core reactivity while reactor shut-down & $\mathrm{RO}_{\text {STOP }}$ & pcm & $\begin{array}{l}\text { Under conditions: } \mathrm{W}=0, \mathrm{Xe}=0, \mathrm{Sm}=\mathrm{Smh}, \\
\mathrm{t}_{\mathrm{mod}}=\mathrm{t}_{\text {fuel }}=\mathrm{t}_{\mathrm{con}}=20^{\circ} \mathrm{C} \\
\mathrm{Cb}=16000 \mathrm{ppm}\end{array}$ \\
\hline
\end{tabular}

${ }^{\mathrm{b}}$ In VVER-1000 calculations Hreg in nominal position is equal to $80 \%$ if there is no special indication 
Russian Research Center "Kurchatov Institute"

Spatial Kinetics Calculations of MOX Fuelled Core. Variant 22

\section{Equilibrium Fuel Cycle with $30 \%$ MOX Loaded Core (Variant 21)}

Every accident calculation is to be executed for uranium reference core and for MOX fuelled core. The equilibrium fuel cycle of the "Uranium base core" with boron BPRs is presented in Figures 3-5 and 3-6. The simplified design of uranium fuel assemblies used here is shown in Figures 3-2, 3-3 and 3-4.

The first MOX core has been formed by introduction of $18 \mathrm{MOX}$ assemblies into the uranium core periphery. The simplified design of MOX fuel assemblies is shown in Fig. 3-1. MOX fuel isotopic composition is presented in Table 3-1. The fissile plutonium enrichments are chosen, according to preliminary estimations, to ensure a reasonable value of pin power peaking factor in assembly. Equilibrium fuel cycle pattern of MOX fuelled core with 54 Plutonium assemblies is shown in Fig. 3-7 and Fig. 3-8. It is named "MOX core".

Characteristics of fuel rods, fuel assemblies, absorbers and boron poison rods are presented in Tables 3-2, 3-3, 3-4, 3-5, 3-6 and 3-7. Control rods grouping in VVER1000 is presented in Fig. 3-9. The bank 10 is a regulating one inserted constantly into the core in the process of fuel irradiation. Assemblies' numeration is shown in Fig. 3-10.

The simplified structure of VVER-1000 radial reflector is presented in Fig. 3-11. In fine-mesh calculations that are carried out in KI the radial VVER-1000 reflector is modelled by "reflector assemblies" of five types (Figures 3-5, 3-12, 3-13, 3-14, 3-15 and 3-16). Zero flux is applied on the outer reflector borders.

Core modelling in axial direction is illustrated in Fig.3-17.

Fuel irradiation simulation is executed under the following conditions:

- The bank 10 is inserted of $20 \%$ core height all over a fuel cycle; the rest of banks are extracted;

- EOC corresponds to $\mathrm{Cb}$ crit $=0$;

- Equilibrium Sm and Xe;

- W = Wnom;

$-t_{\text {entry }}=287^{\circ} \mathrm{C}$. 
Russian Research Center "Kurchatov Institute"

Spatial Kinetics Calculations of MOX Fuelled Core. Variant 22

Table 3-1. Composition of Weapons Grade Plutonium

\begin{tabular}{|c|c|c|c|c|}
\hline \multicolumn{5}{|c|}{ Isotope / content (W. \%) } \\
\hline $\mathrm{Pu}-238$ & $\mathrm{Pu}-239$ & $\mathrm{Pu}-240$ & $\mathrm{Pu}-241$ & $\mathrm{Pu}-242$ \\
\hline 0.0 & 93.0 & 6.0 & 1.0 & 0.0 \\
\hline
\end{tabular}

Table 3-2. Main Core Parameters

\begin{tabular}{|l|l|l|}
\hline Parameter & Units & Value \\
\hline Thermal Power & $\begin{array}{l}\text { MW } \\
\text { thermal }\end{array}$ & 3000 \\
\hline Electrical Power & $\mathrm{MW}$ & 1000 \\
\hline Number of Coolant Loops & & 4 \\
\hline Number of Fuel Assemblies & & 163 \\
\hline Core Equivalent Diameter & $\mathrm{m}$ & 3.164 \\
\hline Core Fuel Height & $\mathrm{m}$ & 3.54 \\
\hline Core Volume & $\mathrm{m}^{3}$ & 27.8 \\
\hline Core Power Density & $\mathrm{W} / \mathrm{cm}^{3}$ & 108 \\
\hline Control / Shut off Rod Banks & & 10 \\
\hline Position of Regulating Rod Bank & $\%$ & 80 \\
\hline Reactor Coolant Flow Rate & $\mathrm{m}^{3} / \mathrm{hr}^{3}$ & 84000 \\
\hline Bypass Coolant Flow & $\%$ & 3 \\
\hline Pressure at Core Inlet & $\mathrm{MPa}$ & 16.1 \\
\hline Core Inlet Temperature & ${ }^{\circ} \mathrm{C}$ & 287 \\
\hline
\end{tabular}


Table 3-3. Fuel Assembly Design Parameters

\begin{tabular}{|c|c|c|}
\hline Parameter & Units & Value \\
\hline Shape of Fuel Assembly & & Hexagonal \\
\hline $\begin{array}{l}\text { Distance Across Assembly (between } \\
\text { flats) }\end{array}$ & $\mathbf{c m}$ & 23.4 \\
\hline $\begin{array}{l}\text { Distance Between Fuel Assembly } \\
\text { Centres }\end{array}$ & $\mathbf{c m}$ & 23.6 \\
\hline Fuel Pin Lattice Pitch & $\mathbf{c m}$ & 1.275 \\
\hline $\begin{array}{l}\text { Number of Fuel Pins in Fuel } \\
\text { Assembly }\end{array}$ & & 312 \\
\hline $\begin{array}{l}\text { Number of Guide Tubes for Control } \\
\text { Rods / Burnable Absorber Pins }\end{array}$ & & 18 \\
\hline Inner Diameter of Guide Thimbles & $\mathbf{c m}$ & 1.1 \\
\hline Thickness of Guide Thimbles & $\mathbf{c m}$ & 0.1 \\
\hline Material of Guide Thimbles & & Zirconium Alloy* \\
\hline $\begin{array}{l}\text { Central Instrumentation Tube Inner } \\
\text { Diameter }\end{array}$ & $\mathbf{c m}$ & 1.1 \\
\hline $\begin{array}{l}\text { Thickness of } \quad \text { Central } \\
\text { Instrumentation Tube }\end{array}$ & $\mathbf{c m}$ & 0.1 \\
\hline Material of Central Guide Tube & & Zirconium Alloy * \\
\hline $\begin{array}{l}\text { Number of Spacer Grids in Fuel } \\
\text { Assembly }\end{array}$ & & 13 \\
\hline Material of Spacer Grids & & Zirconium Alloy* \\
\hline Spacer Grid Weight (each) & $\mathbf{K g}$ & $\mathbf{0 . 5 5}$ \\
\hline
\end{tabular}

Compositions Weight percent:

$*$
\begin{tabular}{|l|l|l|}
\hline $\mathrm{Zr}$ & $\mathrm{Nb}$ & Hf \\
\hline 98.97 & 1.0 & 0.03 \\
\hline
\end{tabular}


Russian Research Center "Kurchatov Institute"

Spatial Kinetics Calculations of MOX Fuelled Core. Variant 22

Table 3-4. Uranium Fuel Pin Design Parameters

\begin{tabular}{|l|c|c|}
\hline Parameter & Units & Value \\
\hline Inner Clad Diameter & $\mathrm{cm}$ & 0.772 \\
\hline Clad Thickness & $\mathrm{cm}$ & 0.069 \\
\hline Clad Material & & Zirconium Alloy \\
\hline Clad Density & $\mathrm{g} / \mathrm{cc}$ & $\mathbf{6 . 5 1 5 3}$ \\
\hline Fuel Pellet Diameter & $\mathrm{cm}$ & 0.755 \\
\hline Central Hole Diameter & $\mathrm{cm}$ & $\mathbf{0 . 1 5}$ \\
\hline Fuel Pellet Material & & L.E. UO2 \\
\hline Height of Fuel Column & $\mathrm{cm}$ & 353 (cold) \\
& & 355 (hot) \\
\hline Mass of UO2 in Fuel Pin & $\mathrm{kg}$ & 1.575 \\
\hline
\end{tabular}

Compositions Weight percent:

\begin{tabular}{|c|c|c|}
\hline $\mathbf{Z r}$ & $\mathbf{N b}$ & Hf \\
\hline 98.97 & 1.0 & 0.03 \\
\hline
\end{tabular}


Russian Research Center "Kurchatov Institute"

Spatial Kinetics Calculations of MOX Fuelled Core. Variant 22

Table 3-5. MOX Fuel Pin Design Parameters

\begin{tabular}{|l|c|c|}
\hline Parameter & Units & Value \\
\hline Inner Clad Diameter & $\mathrm{cm}$ & 0.772 \\
\hline Clad Thickness & $\mathrm{cm}$ & $\mathbf{0 . 0 6 9}$ \\
\hline Clad Material & & Zirconium Alloy* \\
\hline Clad Density & $\mathrm{g} / \mathrm{cc}$ & $\mathbf{6 . 5 1 5 3}$ \\
\hline Fuel Pellet Diameter & $\mathrm{cm}$ & $\mathbf{0 . 7 5 5}$ \\
\hline Central Hole Diameter & $\mathrm{cm}$ & $\mathbf{0 . 1 5}$ \\
\hline U-235 Content in MOX Fuel & $\%$ & 0.2 \\
\hline Fuel Pellet Material & & PuO2-UO2 \\
\hline Height of Fuel Column & $\mathrm{cm}$ & 353 (cold) \\
& & 355 (hot) \\
\hline Mass of MOX Fuel in Fuel Pin & $\mathrm{kg}$ & 1.600 \\
\hline
\end{tabular}

Compositions Weight percent:

\begin{tabular}{|c|c|c|}
\hline $\mathbf{Z r}$ & $\mathbf{N b}$ & Hf \\
\hline 98.97 & 1.0 & 0.03 \\
\hline
\end{tabular}


Russian Research Center "Kurchatov Institute"

Spatial Kinetics Calculations of MOX Fuelled Core. Variant 22

Table 3-6. Discrete Burnable Poison Pin Design Parameters

\begin{tabular}{|c|c|c|c|c|}
\hline Parameter & Units & \multicolumn{3}{|c|}{ Value } \\
\hline Clad Inner Diameter & $\mathbf{c m}$ & \multicolumn{3}{|c|}{0.772} \\
\hline Clad Thickness & $\mathbf{c m}$ & \multicolumn{3}{|c|}{0.069} \\
\hline Clad Material & & \multicolumn{3}{|c|}{ Zirconium Alloy* } \\
\hline Clad Density & g/ cc & \multicolumn{3}{|c|}{6.5153} \\
\hline Absorber Diameter & $\mathbf{c m}$ & \multicolumn{3}{|c|}{0.758} \\
\hline Absorber Density & $\mathrm{g} / \mathrm{cc}$ & 2.869 & 2.896 & 2.945 \\
\hline Absorber Composition & & \multicolumn{3}{|c|}{ Boron g/ cc } \\
\hline & & 0.020 & 0.036 & 0.065 \\
\hline B10 & $W \%$ & 0.1278 & 0.2279 & 0.4046 \\
\hline B11 & & 0.5694 & 1.0153 & 1.8028 \\
\hline $\mathbf{A l}$ & & 93.5246 & 91.7424 & 88.5951 \\
\hline $\mathbf{F e}$ & & 0.1952 & 0.1915 & 0.1850 \\
\hline $\mathbf{N i}$ & & 1.9525 & 1.9153 & 1.8496 \\
\hline $\mathrm{Cr}$ & & 1.6780 & 2.9923 & 5.3133 \\
\hline $\mathbf{Z r}$ & & 1.9525 & 1.9153 & 1.8496 \\
\hline
\end{tabular}

Compositions Weight percent:

*

\begin{tabular}{|l|l|l|}
\hline $\mathrm{Zr}$ & Nb & Hf \\
\hline 98.97 & 1.0 & 0.03 \\
\hline
\end{tabular}


Russian Research Center "Kurchatov Institute"

Spatial Kinetics Calculations of MOX Fuelled Core. Variant 22

Table 3-7. Control Rod Design Parameters

\begin{tabular}{|c|c|c|}
\hline Parameter & Units & Value \\
\hline Clad Inner Diameter & $\mathrm{cm}$ & $\mathbf{0 . 7 0 0}$ \\
\hline Clad Thickness & $\mathrm{cm}$ & $\mathbf{0 . 0 6}$ \\
\hline Clad Material & & Stainless Steel \\
\hline Absorber Diameter & $\mathrm{cm}$ & $\mathbf{0 . 7 0 0}$ \\
\hline Absorber Material & & Natural B4C** \\
\hline Absorber Density & $\mathrm{g} / \mathrm{cc}$ & $\mathbf{1 . 8 0}$ \\
\hline
\end{tabular}

Compositions Weight percent:

*

\begin{tabular}{|c|c|c|c|c|}
\hline $\mathrm{C}$ & $\mathrm{Cr}$ & $\mathrm{Ni}$ & $\mathrm{Ti}$ & $\mathrm{Fe}$ \\
\hline 0.12 & 18.5 & 10.5 & 1.0 & 69.88 \\
\hline
\end{tabular}

** Content of ${ }^{10} \mathrm{~B}$ is $19.8 \%$ atoms.

Remark. The lower part $(30 \mathrm{~cm})$ of control rods consists of $\mathrm{Dy}_{2} \mathrm{O}_{3} \mathrm{TiO} 2$ of density $4.9 \mathrm{~g}$ / cc. 


\section{Fig.3-1 . Simplified Design for 3-Zones MOX assembly}

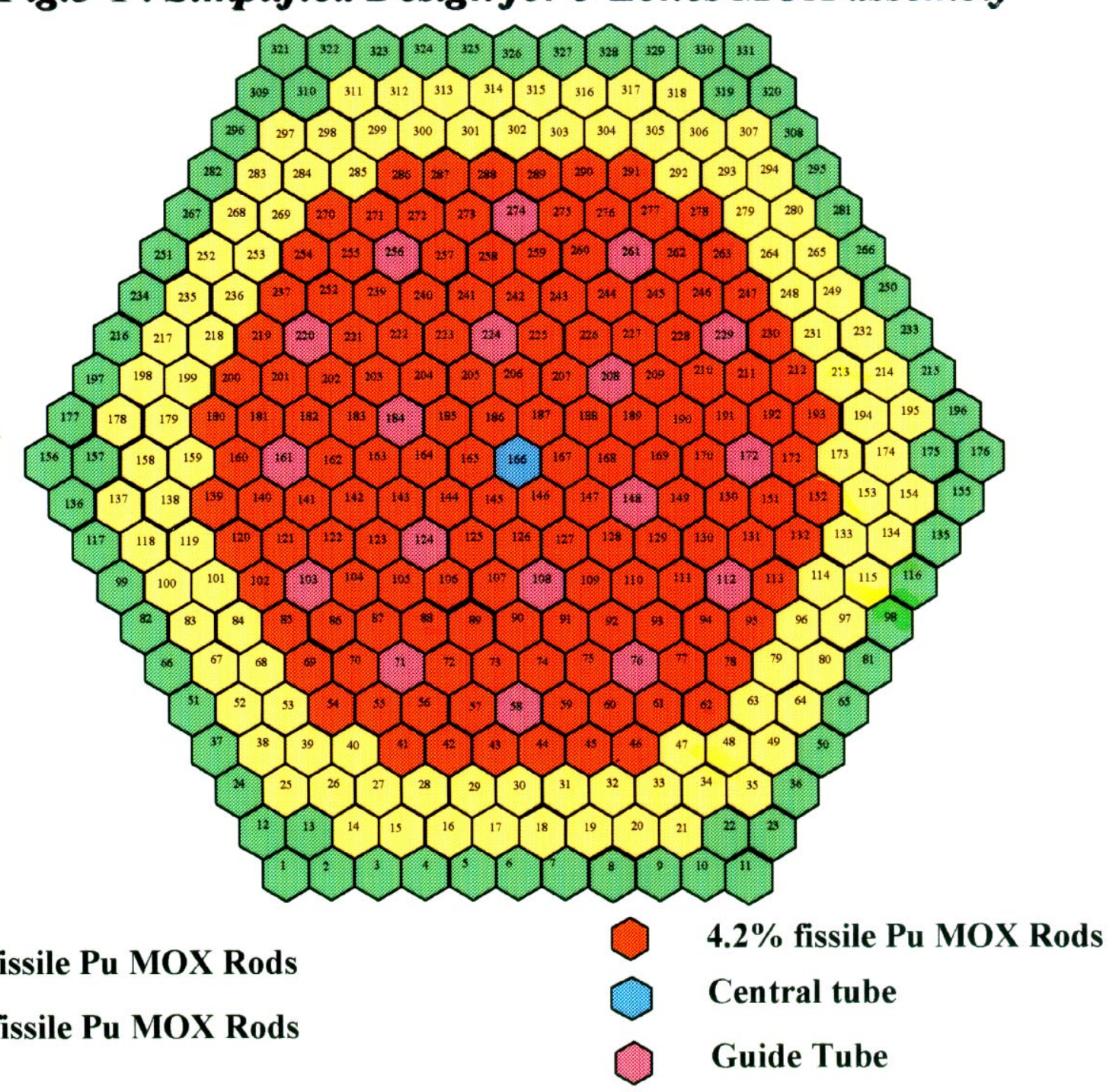


Fig.3-2. Simplified Design for VVER-1000 Fuel Assembly.

\section{Type A}

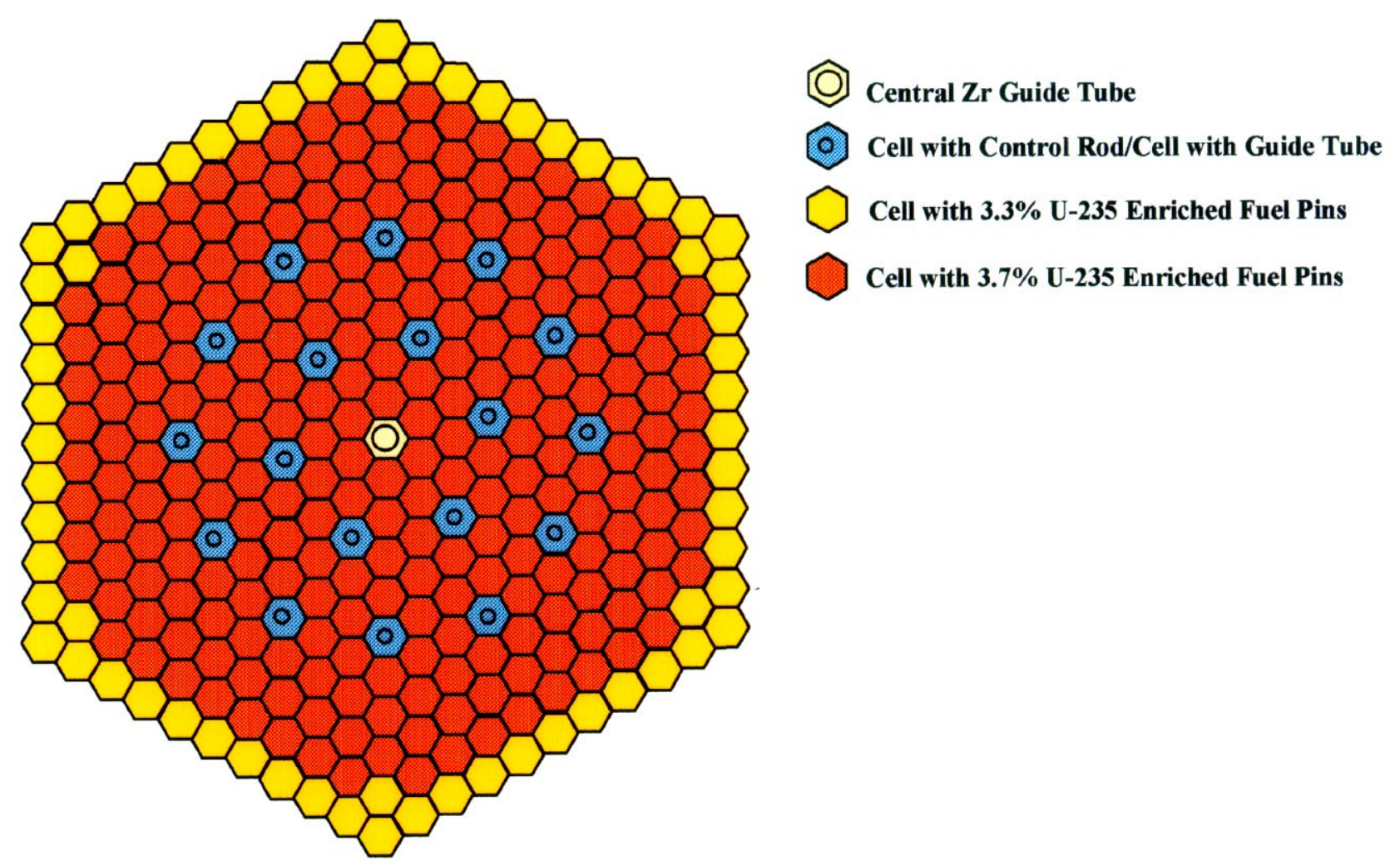




\section{Fig.3-3. Simplified Design for VVER-1000 Fuel Assembly. Type $B, B a$ and $B b$}

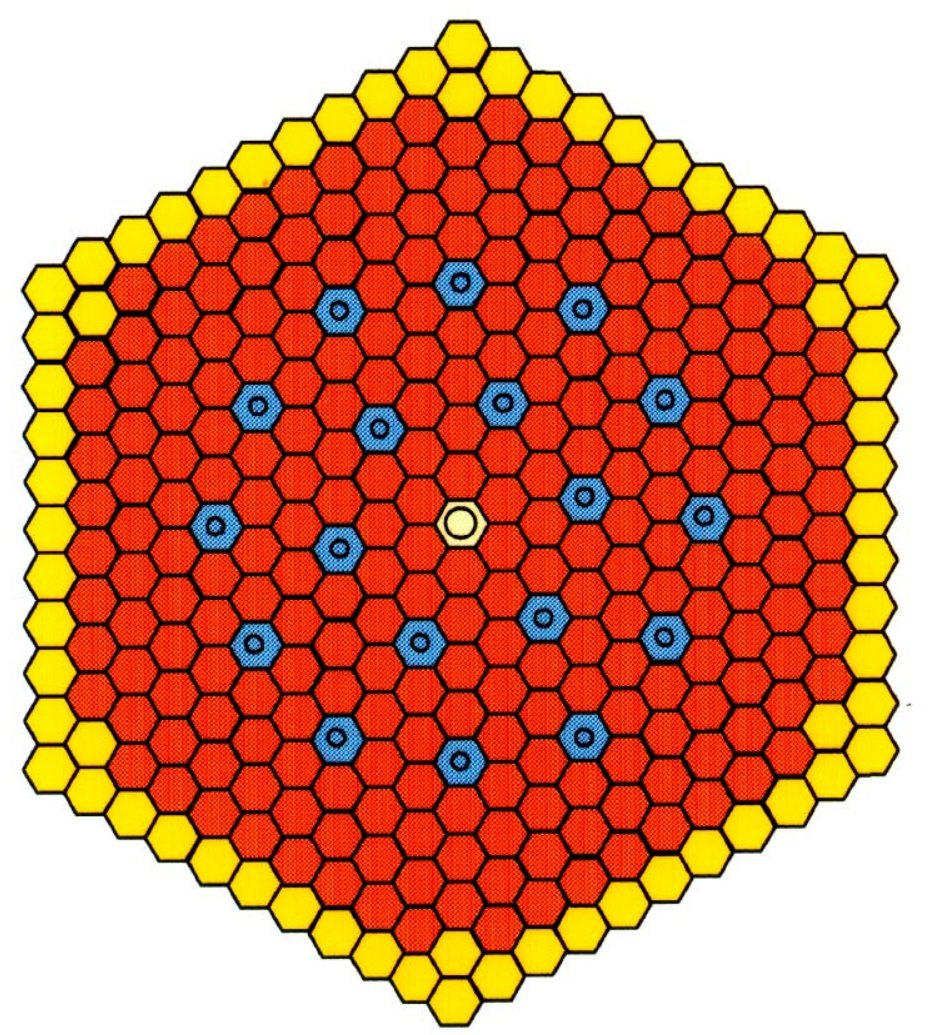

(2) Central Zr Guide Tube

(0) Cell with Burnable Absorber/Cell with Guide Tube

Cell with 3.3\% U-235 Enriched Fuel Pins

Cell with 3.7\% U-235 Enriched Fuel Pins

B - $(0,065 \mathrm{~g} / \mathrm{cc}$ Boron BPRs, removed after 1 st year $)$

Ba - $(0,036 \mathrm{~g} / \mathrm{cc}$ Boron BPRs, removed after 1st year $)$

Bb - $(0,020 \mathrm{~g} / \mathrm{cc}$ Boron BPRs, removed after 1st year $)$ 


\section{Fig.3-4. Simplified Design for VVER-1000 Fuel Assembly. Type C}

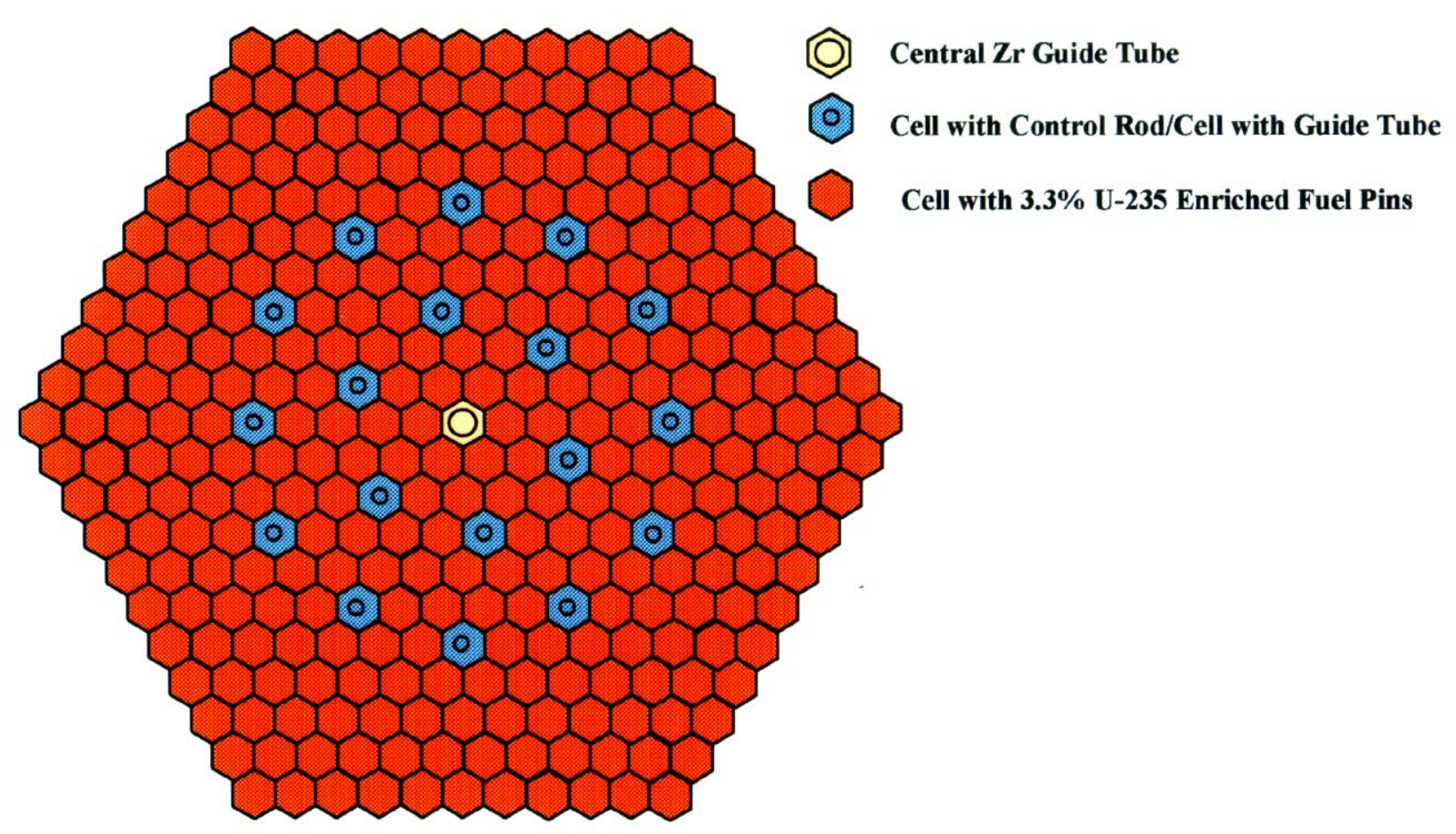

RRC "Kurchatov Institute". Spatial Kinetics Calculations of MOX Fuelled Core. Variant 22 


\section{Fig.3-5. Equilibrium Loading Pattern for Base Uranium Core with Boron}

BPRs, Core $60^{\circ}$ Sector

An - 3,7\% Enrichment graded by 3,3\% Replaced After 3 Years (No BPRs)

Bn - 3,7\% Enrichment graded by 3,3\% Replaced After 3/4 Years $(0,065 \mathrm{~g} / \mathrm{cc}$ Boron BPRs, removed after 1st year)

Cn - 3,3\% Enrichment Replaced After 3 Years (No BPRs)

1-28 - Positions in 60 Degree Sector n - Current Cycle of Fuel Assembly Symbol e.g. S - Position of a Fuel Assembly During Lifetime in Core

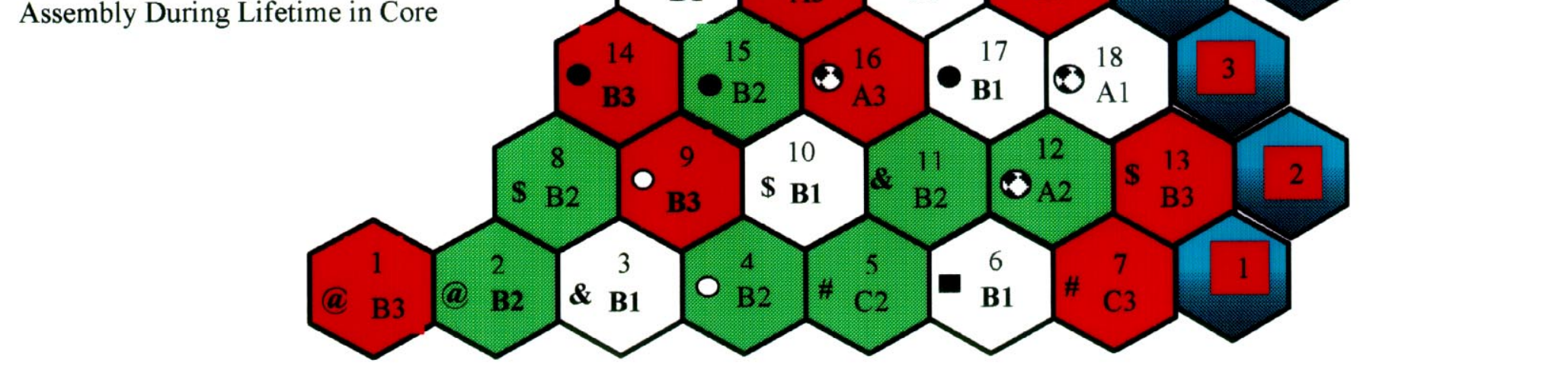

1st year assembly

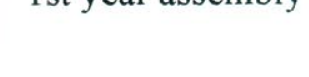

2nd year assembly

$3 \mathrm{~d}$ year assembly

4 th year assembly

Reflector

RRC "Kurchatov Institute". Spatial Kinetics Calculations of MOX Fuelled Core. Variant 22 
Russian Research Center "Kurchatov Institute"

Spatial Kinetics Calculations of MOX Fuelled Core. Variant 22

BURNUP(KG F-PIT FUEL) BOC

BURNUP(KG F-P/T FUEL) EOC

RELATIVE POWER BOC

RELATIVE POWER EOC

28

3.4552E+01

3.7970E+01

2.9703E-01

3.7042E-01

26

27

$9.4878 E+000.0000 E+00$

2.0191E+01 7.9323E+00

$1.0155 \mathrm{E}+007.2646 \mathrm{E}-01$

1.0601E+00 8.0797E-01

23

24

25

1.4940E+01 0.0000E+00 3.0004E+01

2.7518E+01 1.1910E+01 3.5474E+01

1.2434E+00 1.1149E+00 4.9584E-01

1.1993E+00 1.1848E+00 5.6691E-01

$19220 \quad 21 \quad 22$

$0.0000 \mathrm{E}+00$ 2.2363E+01 $0.0000 \mathrm{E}+003,0316 \mathrm{E}+01$

1.3348E+01 3.3883E+01 1.2624E+01 3.5767E+01

1.3011E+00 1.1420E+00 1.2370E+00 4.9398E-01

1.2859E+00 1.0971E+00 1.2025E+00 5.6514E-01

$\begin{array}{lllll}14 & 15 & 16 & 17 & 18\end{array}$

2.9106E+01 1.4296E+01 2.2474E+01 0.0000E+00 0.0000E+00

3.9180E+01 2.6576E+01 3.3950E+01 1.1882E+01 7.9817E+00

$1.0037 E+001.2318 E+001.1365 E+001.1111 E+00$ 7.3092E-01

9.6843E-01 1.1608E+00 1.0941E+00 1.1831E+00 8.1290E-01
8
9
10
11
12
13

1.6166E+01 2.8873E+01 0.0000E+00 1.5729E+01 9.5718E+00 3.0550E+01

2.8153E+01 3.8955E+01 1.3314E+01 2.8146E+01 2.0285E+01 3.4214E+01

1.2283E+00 1.0024E+00 1.2964E+00 1.2247E+00 1.0154E+00 3.1949E-01

1.1225E+00 9.7048E-01 1.2839E+00 1.1868E+00 1.0619E+00 3.9543E-01

$\begin{array}{llllllll}1 & 2 & 3 & 4 & 5 & 6 & 7\end{array}$

3.0565E+01 1.6180E+01 0.0000E+00 1.4294E+01 1.5026E+01 0.0000E+00 2.9914E+01 4.0498E+01 2.8270E+01 1.2886E+01 2.5894E+01 2.7341E+01 1.2419E+01 3.5531E+01 $1.0298 E+001.2611 E+001.2748 E+001.1859 E+001.2374 E+001.1684 E+004.9960 E-01$ 9.2825E-01 1.1160E+00 1.2372E+00 1.0874E+00 1.1626E+00 1.2325E+00 5.9583E-01

Fig. 3-6. Uranium Zone. Assembly Burnup, Relative Power 


\section{Fig.3-7. Equilibrium Loading Pattern for MOX Fueled Core with 54 MOX Fuel Assemblies, Core $60^{\circ}$ Sector}

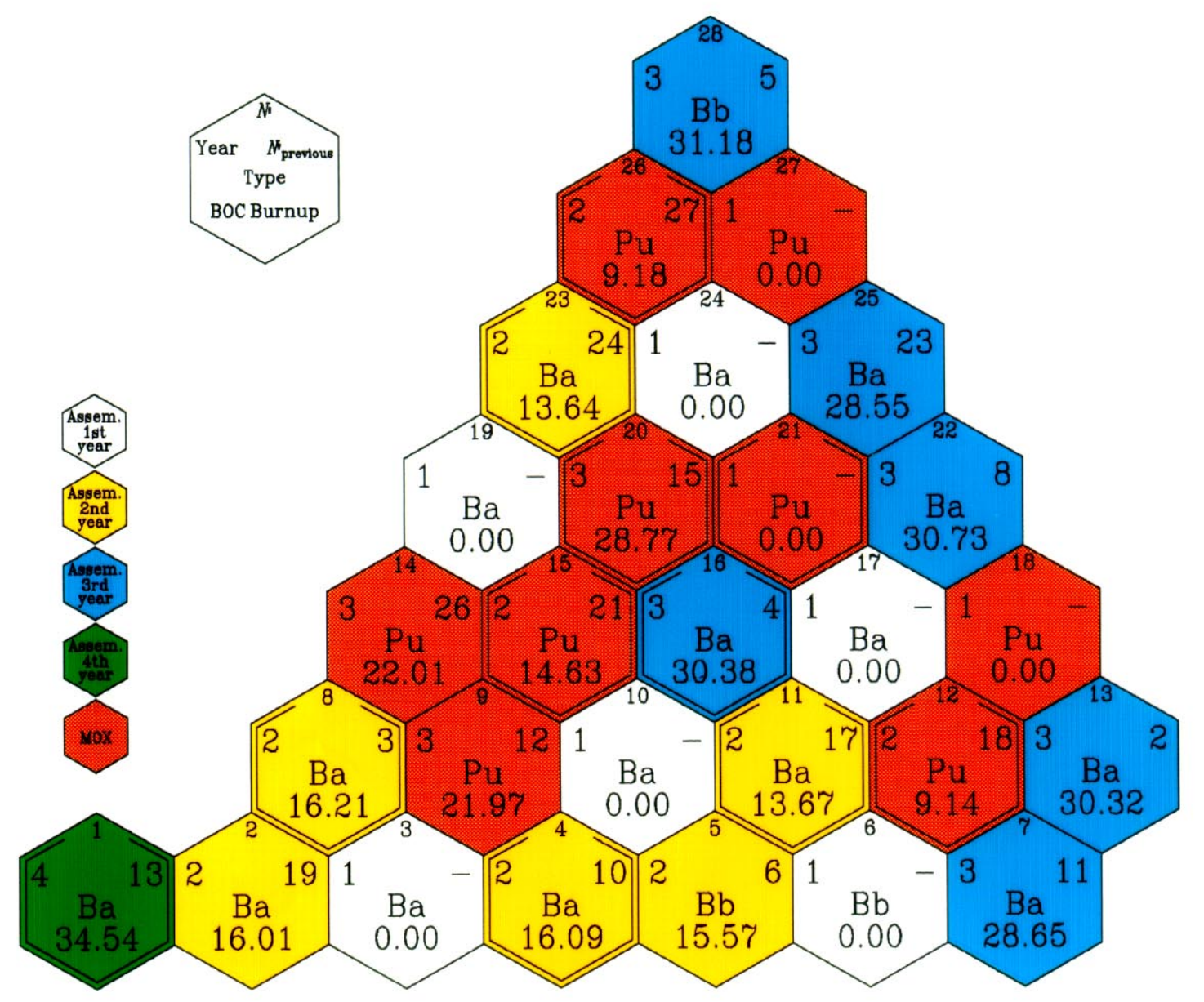

RRC "Kurchatov Institute". Spatial Kinetics Calculations of MOX Fuelled Core. Variant 22 
BURNUP(KG F-P/T FUEL) BOC BURNUP(KG F-P/T FUEL) EOC RELATIVE POWER BOC RELATIVE POWER EOC

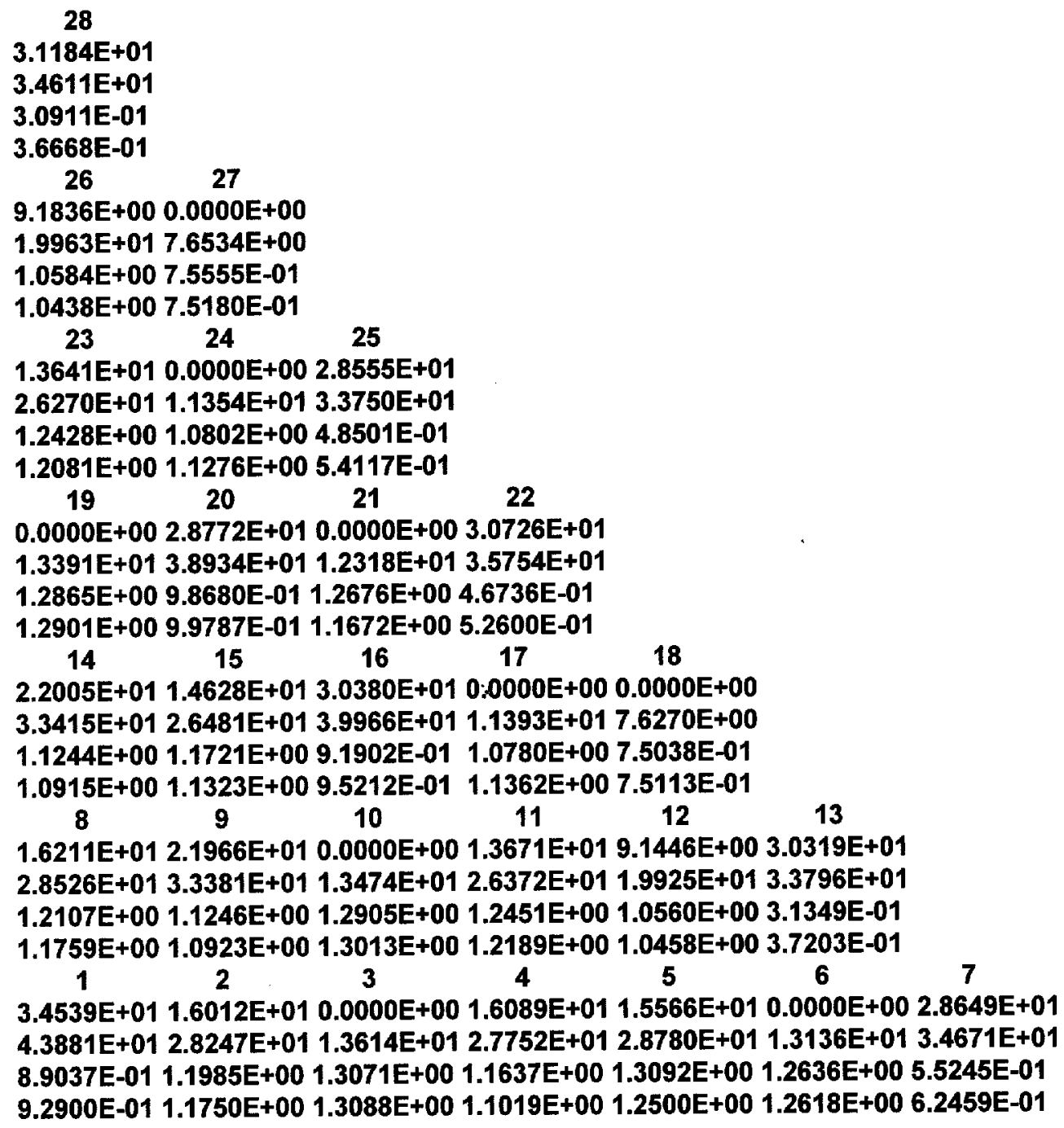

Fig. 3-8. MOX Zone. Assembly Burnup, Relative Power. 


\section{Fig.3-9. Control Rods Grouping and Positions of in-core self-powered detectors}

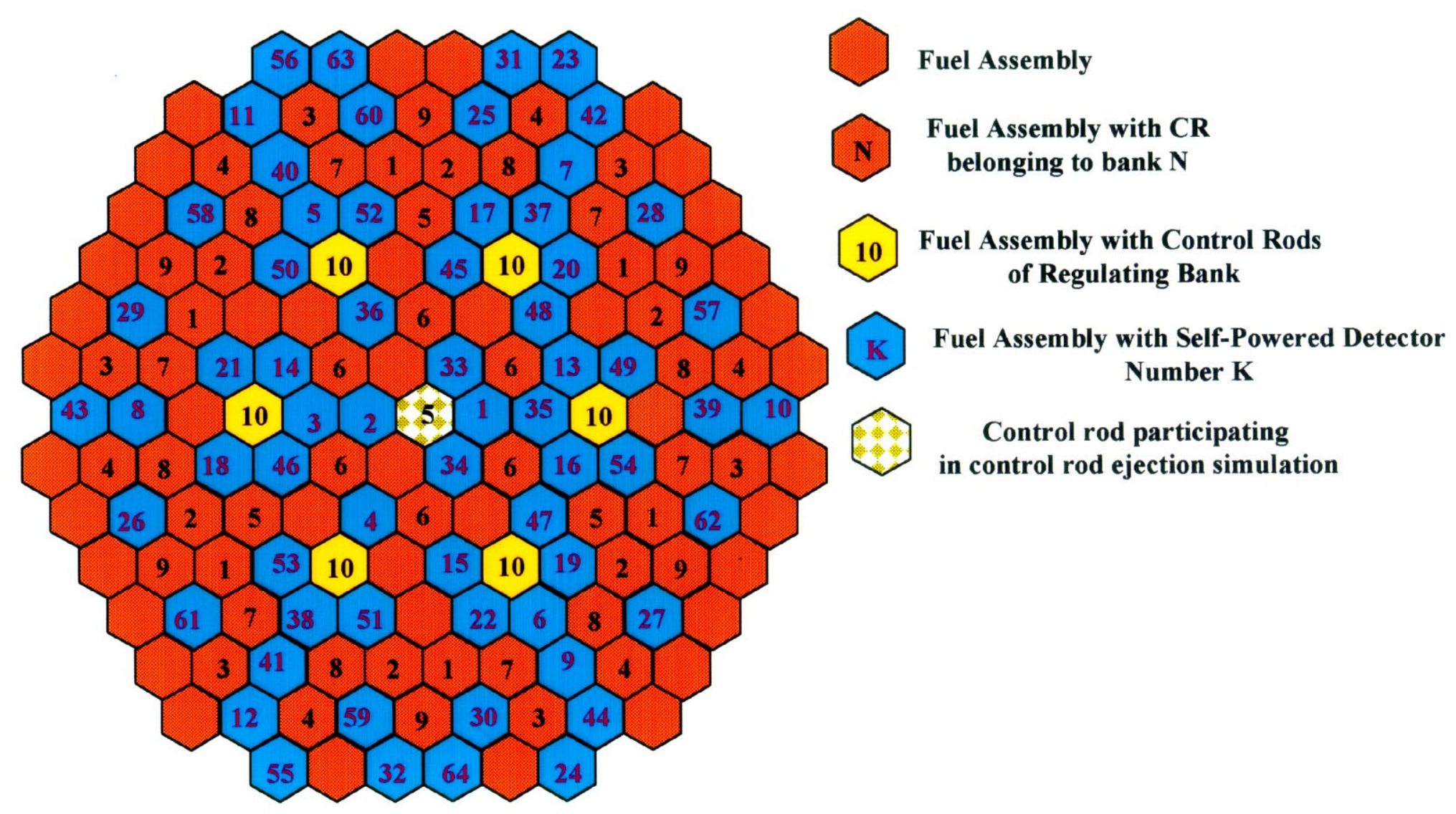

RRC "Kurchatov Institute". Spatial Kinetics Calculations of MOX Fuelled Core. Variant 22 
Fig.3-10. Assemblies Numeration in VVER-1000 Core

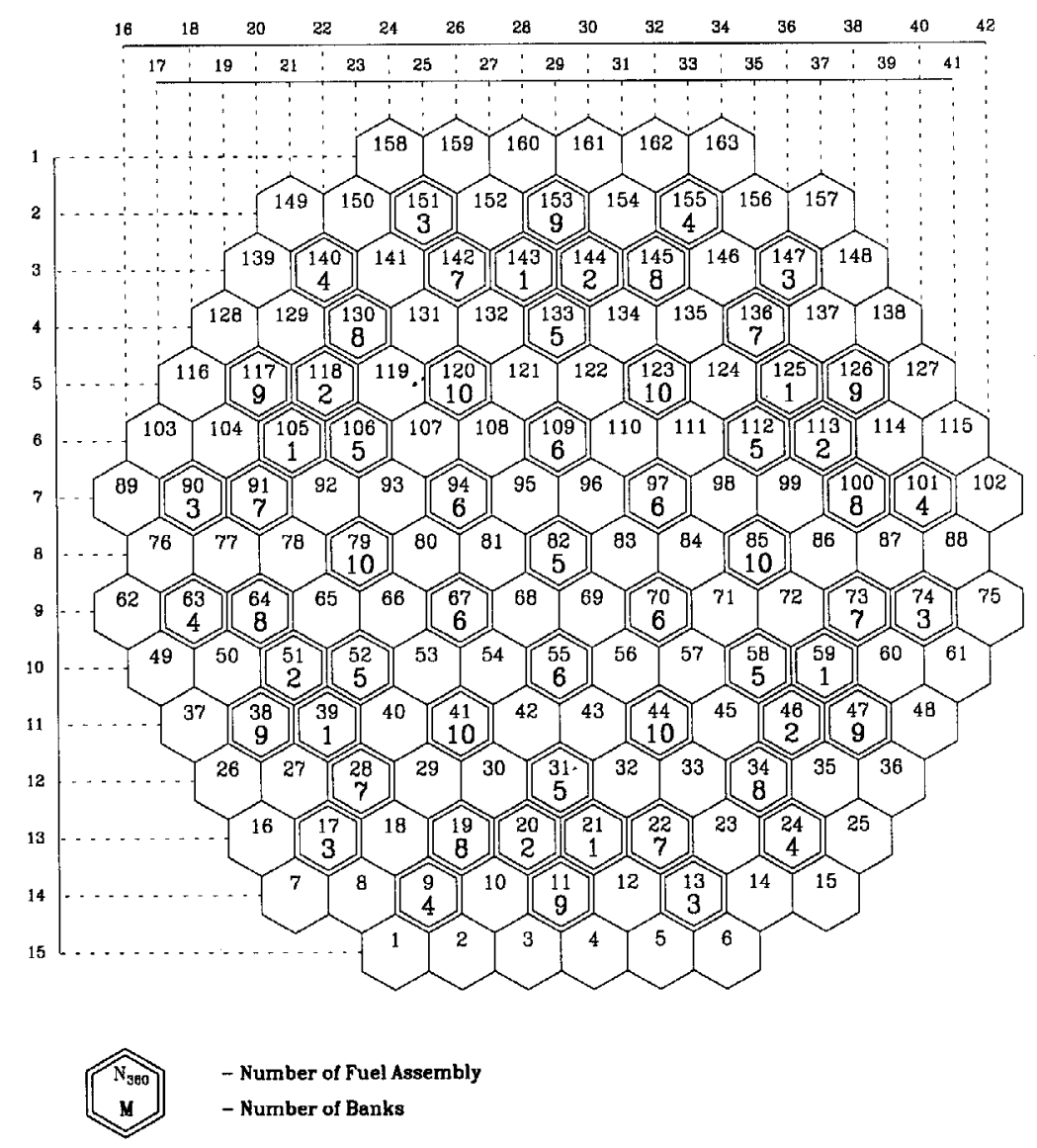

RRC "Kurchatov Institute". Spatial Kinetics Calculations of MOX Fuelled Core. Variant 22 
Fig.3-11. Model of VVER-1000 Reflector

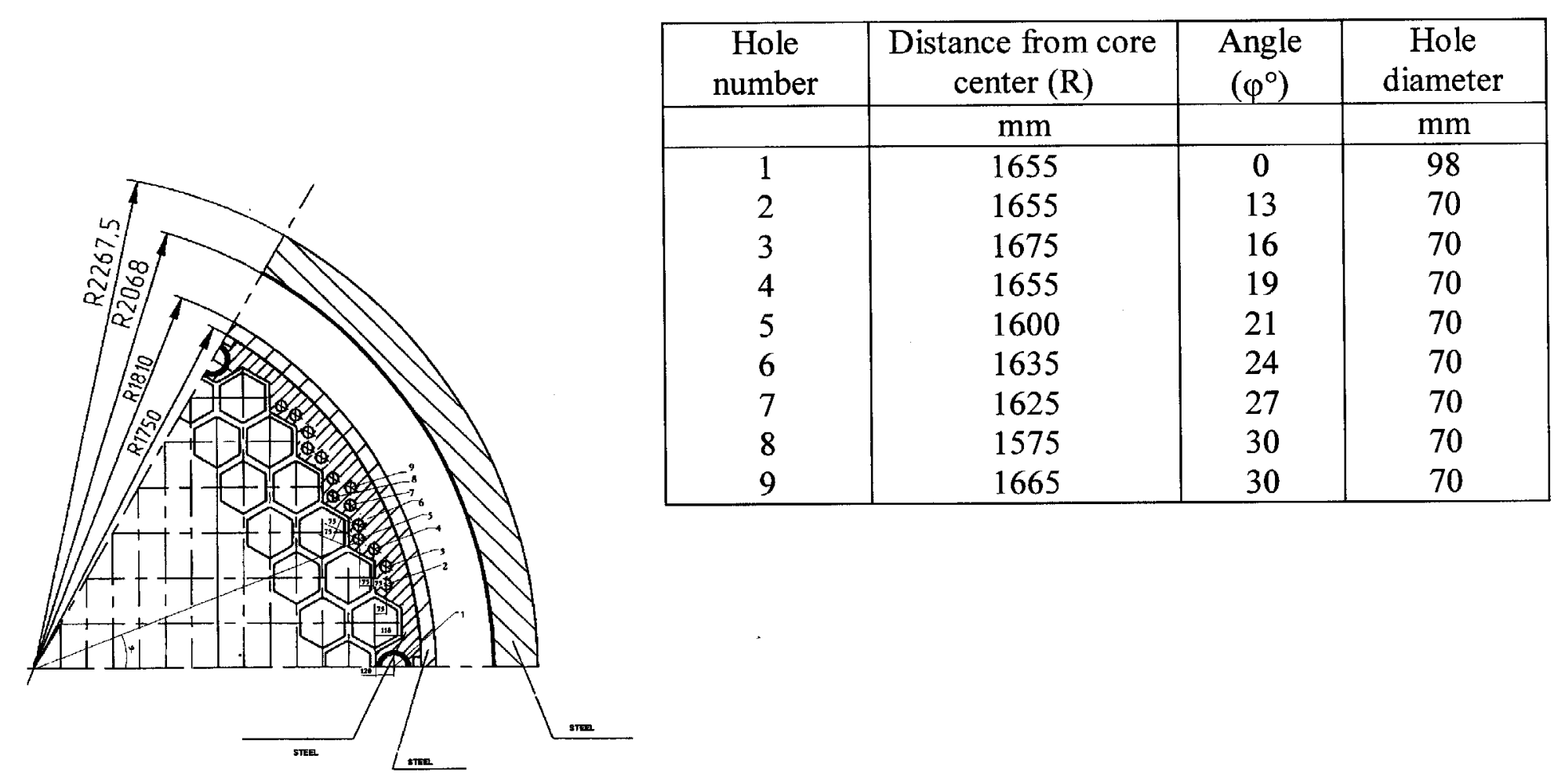

RRC "Kurchatov Institute". Spatial Kinetics Calculations of MOX Fuelled Core. Variant 22 
Russian Research Center "Kurchatov Institute"

Spatial Kinetics Calculations of MOX Fuelled Core. Variant 22

Fig. 3-12. Reflector “Assembly" of Type 1

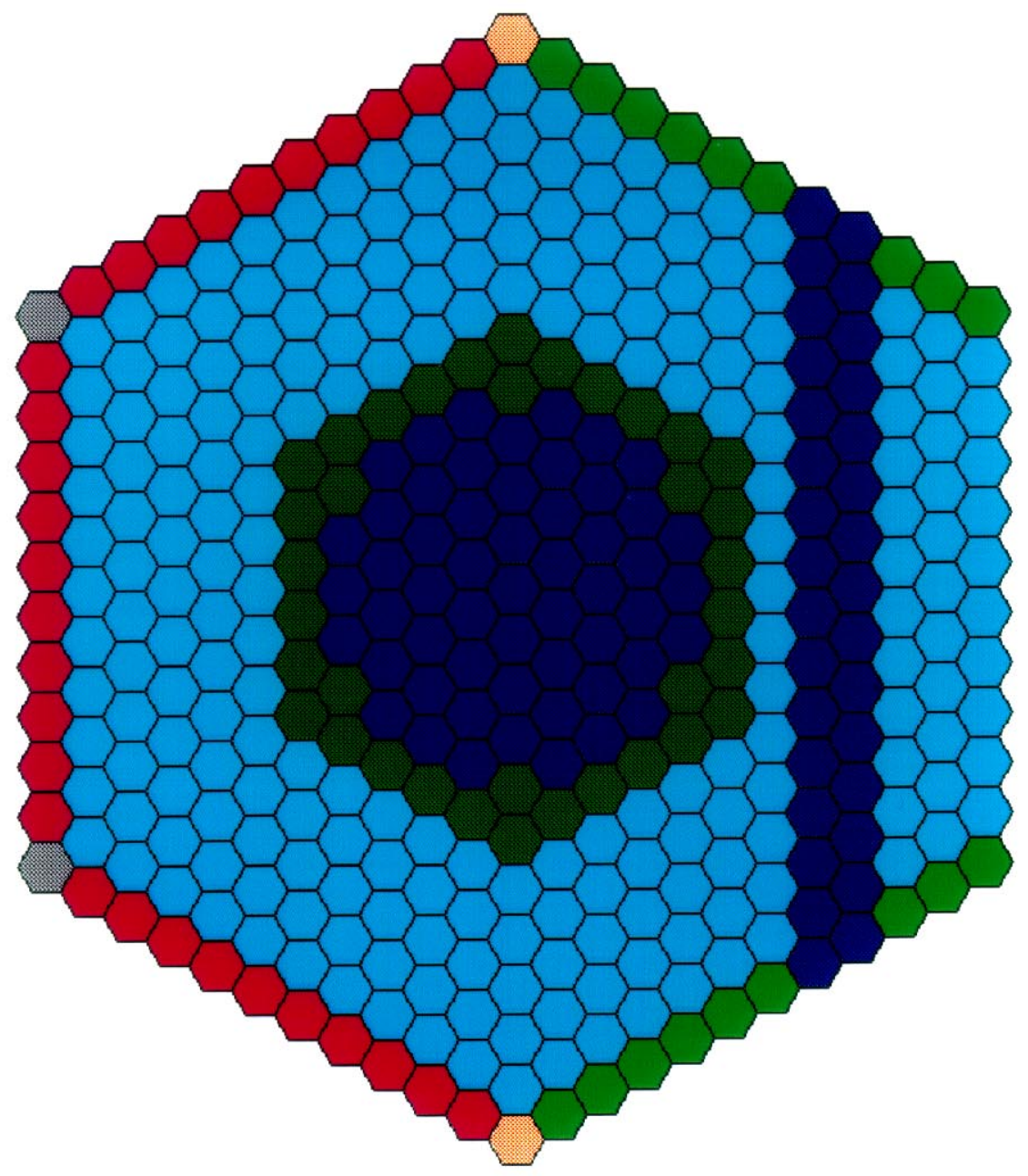

Steel 100 Water 0
Steel 0 Water 100

Steel 26 Water 74 
Russian Research Center "Kurchatov Institute" Spatial Kinetics Calculations of MOX Fuelled Core. Variant 22

Fig. 3-13. Reflector "Assembly" of Type 2

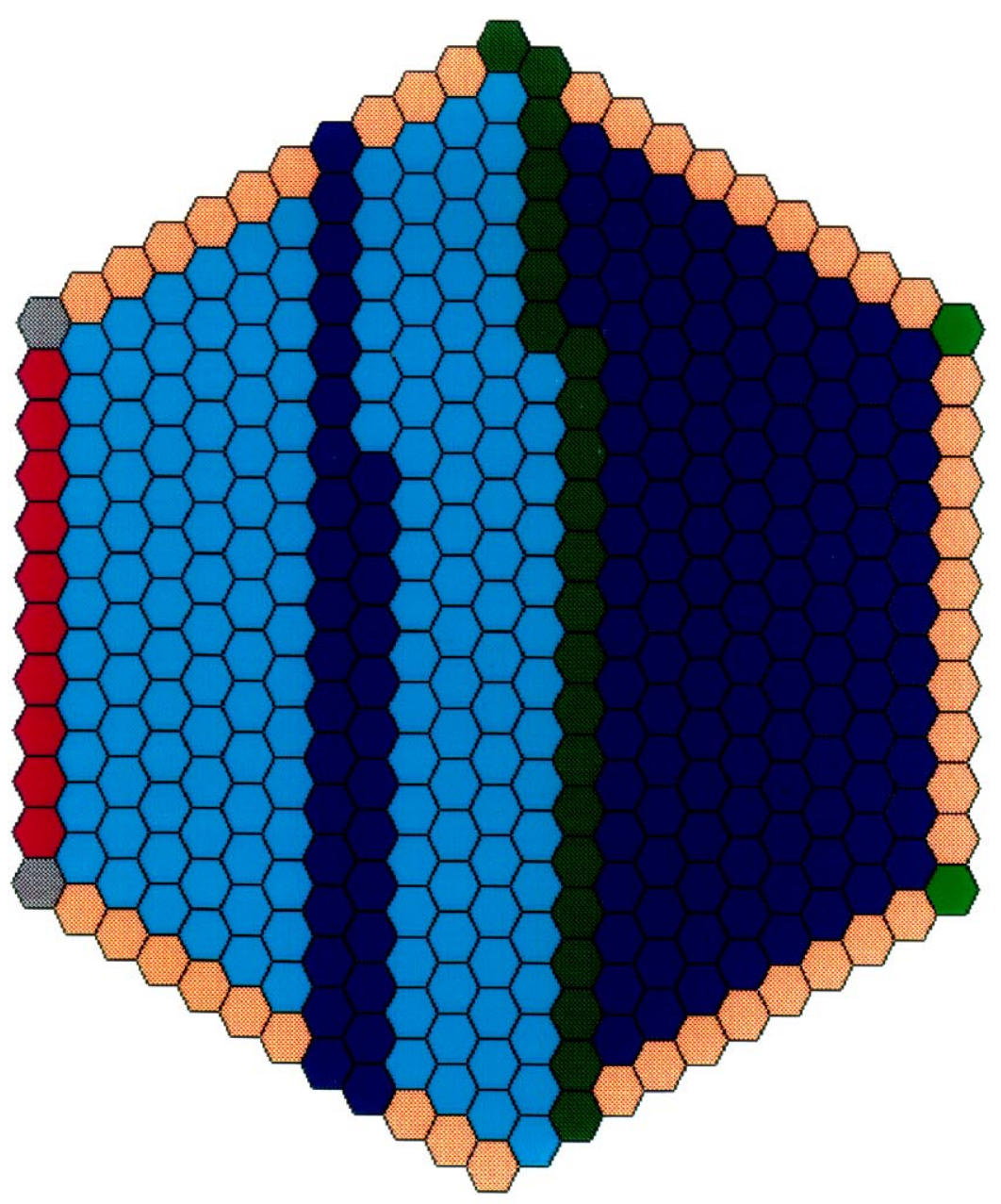

$\bigcirc$ Steel 100 Water 0

Steel 0 Water 100

Steel 26 Water 74

Corner
(2) Steel 50 Water 50

Steel 75 Water 25

Steel 100 Water 0

$\bigcirc$ Plane 
Russian Research Center "Kurchatov Institute"

Spatial Kinetics Calculations of MOX Fuelled Core. Variant 22

Fig. 3-14. Reflector "Assembly" of Type 3

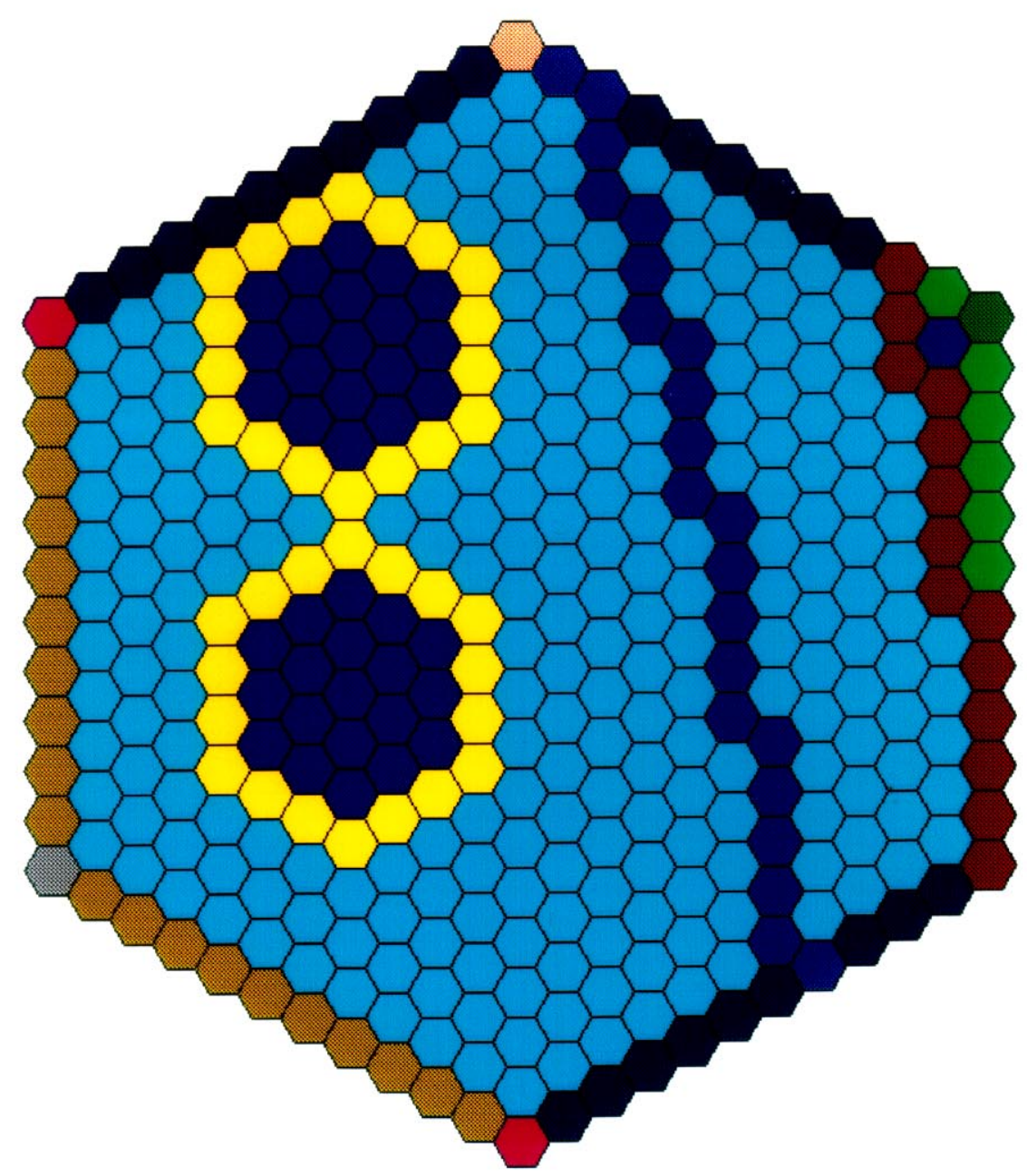

Steel 100 Water 0

Steel 0 Water 100

Steel 50 Water 50

Plane

Steel 75 Water 25

Steel 100 Water 0 (2teel 11 Water 89

\section{Corner}

Steel 100 Water 0

Steel 50 Water 50

Steel 26 Water 74 
Russian Research Center "Kurchatov Institute"

Spatial Kinetics Calculations of MOX Fuelled Core. Variant 22

Fig. 3-15. Reflector "Assembly" of Type 4

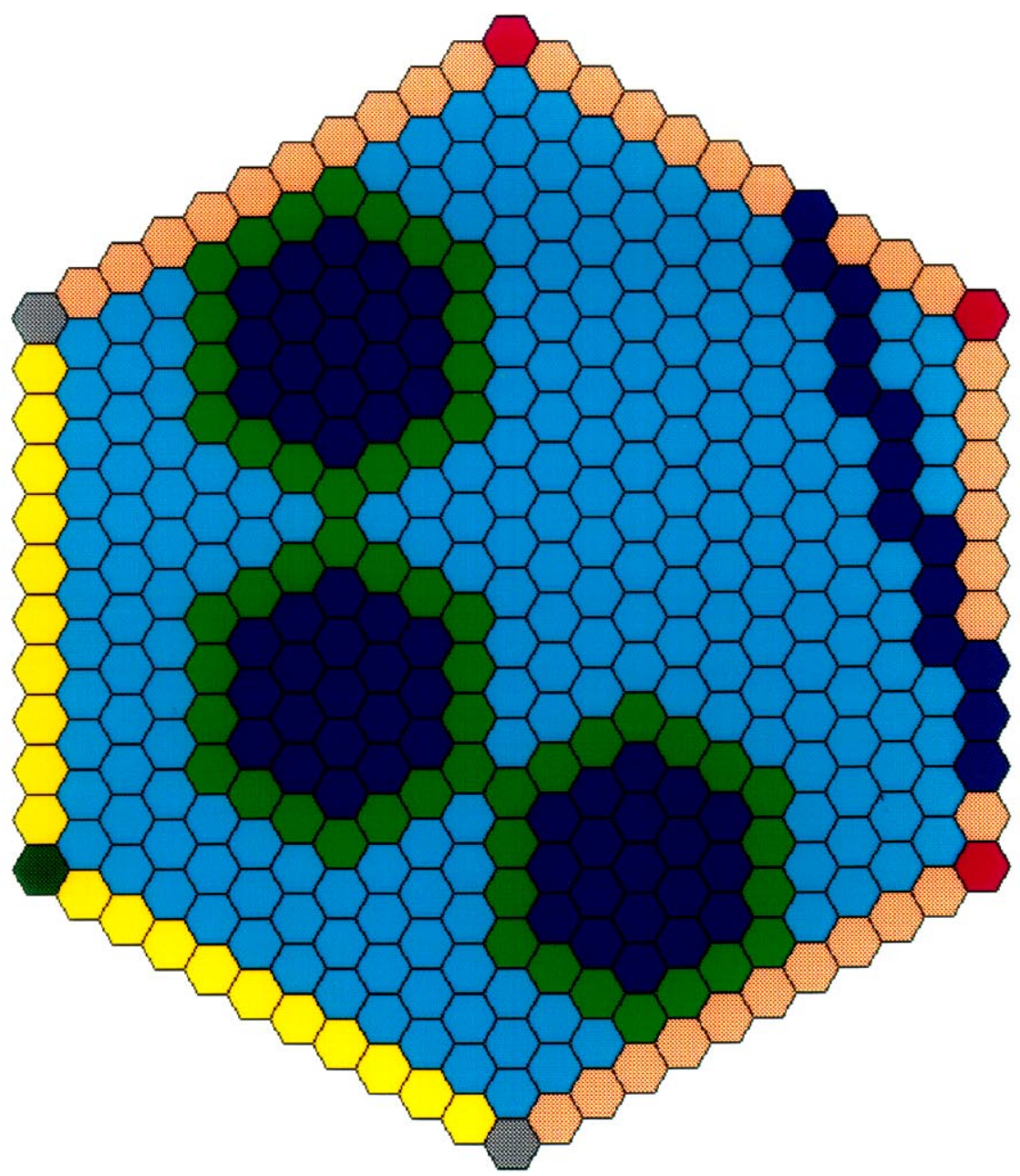

Steel 0 Water 100

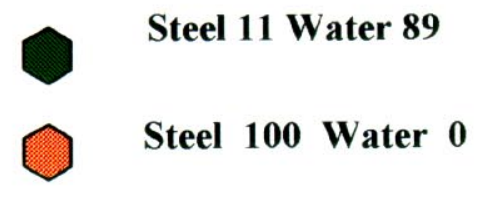

Steel 50 Water 50

Steel 26 Water 74 
Russian Research Center "Kurchatov Institute"

Spatial Kinetics Calculations of MOX Fuelled Core. Variant 22

Fig. 3-16. Reflector "Assembly" of Type 5

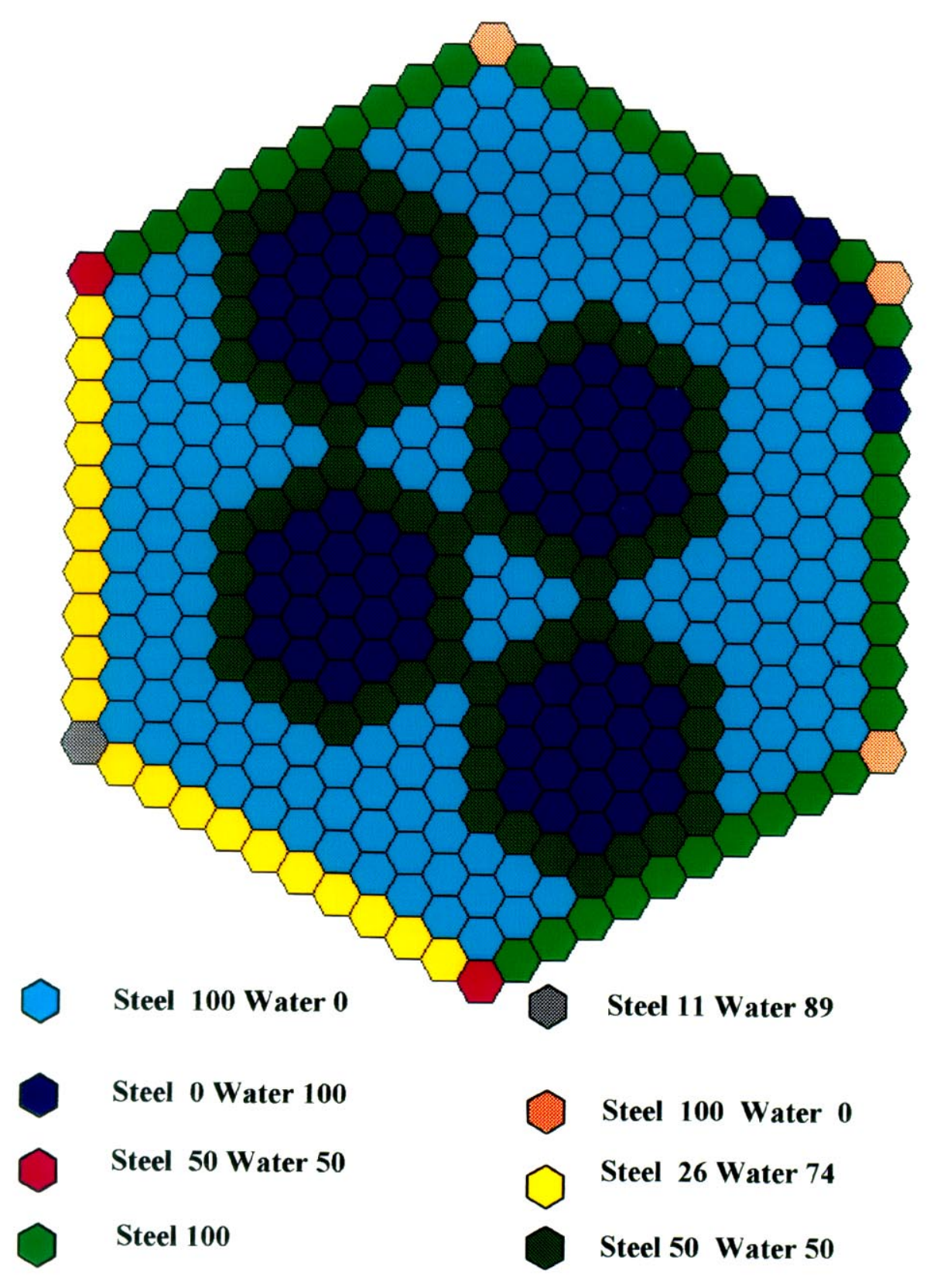


Fig.3-17. Core Design. Material Contents (Vol\%) in Axial Direction

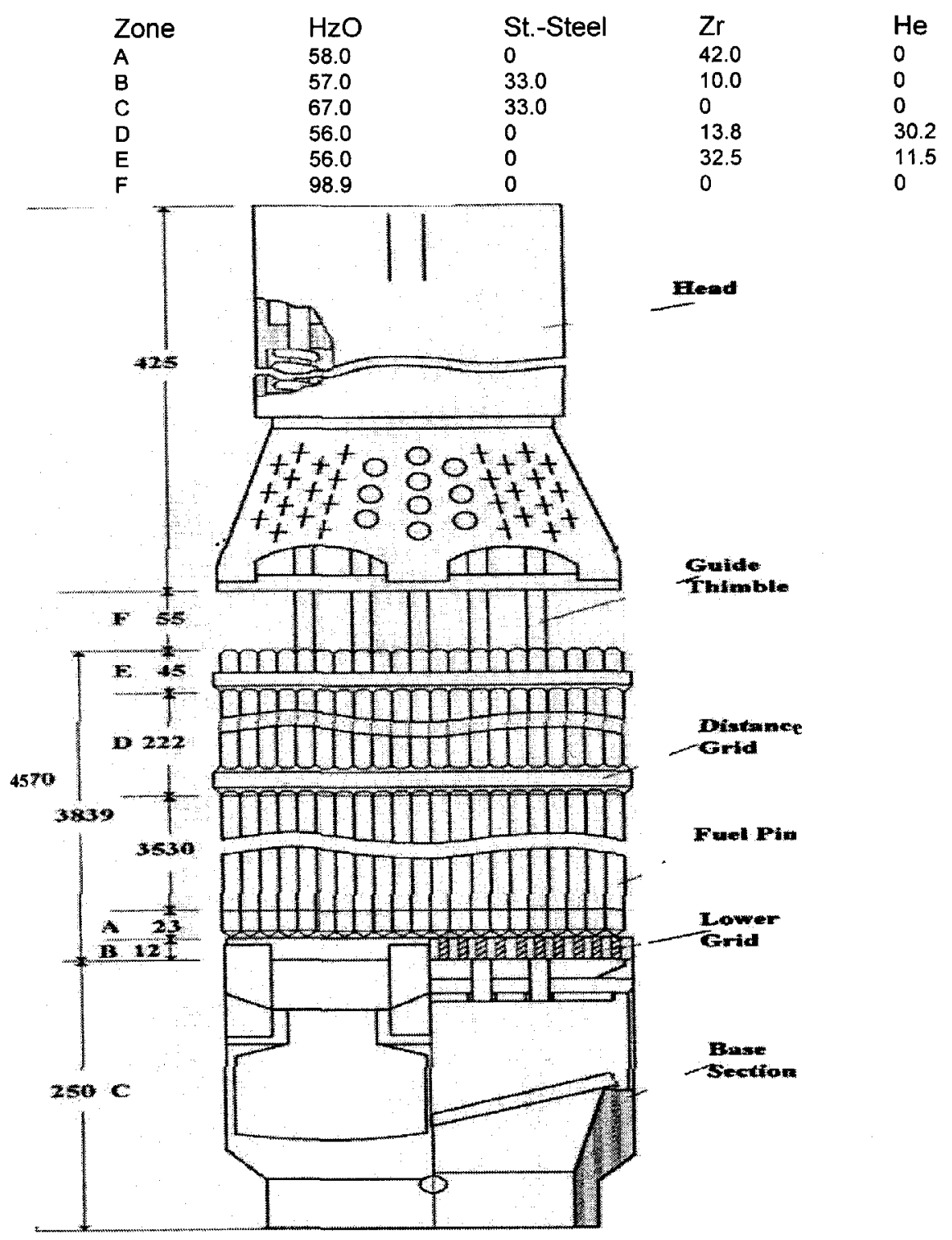

RRC "Kurchatov Institute”. Spatial Kinetics Calculations of MOX Fuelled Core. Variant 22 


\section{Russian Research Center "Kurchatov Institute" \\ Spatial Kinetics Calculations of MOX Fuelled Core. Variant 22}

\section{Central Control Rod Ejection from the VVER-1000 Core}

4.1. Process being investigated: Central control rod is ejected by pressure drop caused by destroying of the moving mechanism cover.

\subsection{Initial state of the core:}

- EOC for equilibrium refueling regime, see Figures 4-1, 4-2.

- Thermal power of reactor - nominal power level $\mathrm{W}_{\text {nom }}$.

- Coolant flow rate $-84000 \mathrm{~m}^{3} / \mathrm{h}$.

- Positions of control rods regulating bank and central control rod are - $20 \%$ from the core bottom.

- Xenon and samarium concentrations - equilibrium values corresponding to the reactor nominal power level.

\subsection{Scenario of transient.}

Central control rod is ejected by pressure drop caused by destroying of the moving mechanism cover. Time point of ejection start corresponds to $0.1 \mathrm{sec}$. Initial control rod position - $20 \%$ from the core bottom. Duration of ejection is $0.05 \mathrm{sec}$. The scram is actuated at time point $1.0 \mathrm{sec}$. Duration of the rod drop is $4 \mathrm{sec}$.

\subsection{Main calculation results.}

For the uranium zone the worth of ejected cluster is $87.4 \mathrm{pcm}$, and for the MOX zone it is $93.6 \mathrm{pcm}$.

The calculation results of dynamical processes are shown in Figs. 4-3 - 4-8. Figs. 4-5 - 4-8 present the characteristics of «hot» channel with sampling all over the core.

The «hot» channel power was taken as

$$
\mathrm{q}_{\text {hot.chan.ij }}=\mathrm{q}_{\mathrm{ij}} * \mathrm{~K}_{\mathrm{eng}} * \mathrm{~K}_{\mathrm{k}}{ }^{\max } \text {, }
$$

where $\mathrm{q}_{\mathrm{ij}}$ is the power averaged over the calculation prism $\mathrm{ij}$, with $\mathrm{j}$ being the number of layer in the core height; $\mathrm{i}$ - the FA number;

$\mathrm{K}_{\text {eng }}$ - is the engineering margin coefficient accounting for the errors in the calculation of power averaged over FA cross section, $\mathrm{q}_{\mathrm{ij}}$, and of the flow rate through the i-th FA;

$$
\mathrm{K}_{\mathrm{k}}^{\max } \text { - is the maximum radial peaking coefficient in the hottest FA. }
$$


Russian Research Center "Kurchatov Institute"

\section{Spatial Kinetics Calculations of MOX Fuelled Core. Variant 22}

In the present work:

$$
\begin{aligned}
& \mathrm{K}_{\text {eng }}=1.16, \\
& \mathrm{~K}_{\mathrm{k}}=1.08
\end{aligned}
$$

Concluding it can be said that the transition to MOX fuel does not noticeably alter the dynamical process. 
Russian Research Center "Kurchatov Institute"

Spatial Kinetics Calculations of MOX Fuelled Core. Variant 22

FA NUMBER

BURNUP(KG F-P/T FUEL)

RELATIVE POWER

TEMPERATURE DROP

28

3.7622E+01

4.0063E-01

1.2944E+01

$26 \quad 27$

$1.9201 E+017.1680 E+00$

1.1399E+00 8.7605E-01

3.6828E+01 2.8304E+01

$23 \quad 24 \quad 25$

2.6445E+01 1.0807E+01 3.4939E+01

$1.2528 E+001.2681 E+00 \quad 6.1422 E-01$

4.0476E+01 4.0970E+01 1.9845E+01

$\begin{array}{llll}19 & 20 & 21 & 22\end{array}$

1.2328E+01 3.2896E+01 1.1496E+01 3.5234E+01

1.2386E+00 1.1472E+00 1.2955E+00 6.1234E-01

4.0019E+01 3.7063E+01 4.1857E+01 1.9784E+01

$\begin{array}{lllll}14 & 15 & 16 & 17 & 18\end{array}$

3.8448E+01 2.5599E+01 3.2967E+01 1.0780E+01 7.2127E+00

8.8331E-01 1.1508E+00 1.1438E+00 1.2664E+00 8.8160E-01

2.8539E+01 3.7181E+01 3.6954E+01 4.0914E+01 2.8483E+01

$\begin{array}{llllll}8 & 9 & 10 & 11 & 12 & 13\end{array}$

2.7236E+01 3.8225E+01 1.2296E+01 2.7084E+01 1.9293E+01 3.3842E+01

1.0107E+00 8.8599E-01 1.2362E+00 1.2394E+00 1.1420E+00 4.2781E-01

3.2653E+01 2.8625E+01 3.9939E+01 4.0044E+01 3.6898E+01 1.3822E+01

$\begin{array}{lllllll}1 & 2 & 3 & 4 & 5 & 6 & 7\end{array}$

3.9690E+01 2.7321E+01 1.1944E+01 2.5385E+01 2.6401E+01 1.1301E+01 3.4976E+01 5.8580E-01 9.5214E-01 1.0889E+00 8.3411E-01 1.1438E+00 1.2963E+00 6.4059E-01 1.8926E+01 3.0762E+01 3.5181E+01 2.6949E+01 3.6953E+01 4.1880E+01 2.0696E+01

Fig. 4-1. Uranium zone. Assembly burnup, relative power and temperature drop for control rod ejection calculation. 
Russian Research Center "Kurchatov Institute"

Spatial Kinetics Calculations of MOX Fuelled Core. Variant 22

FA NUMBER

BURNUP(KG F-PIT FUEL)

RELATIVE POWER

TEMPERATURE DROP

28

$3.4268 \mathrm{E}+01$

3.9600E-01

1.2794E+01

26

27

$1.8990 \mathrm{E}+016.9459 \mathrm{E}+00$

1.1223E+00 8.1328E-01

3.6260E+01 2.6276E+01

23224

2.5186E+01 1.0306E+01 3.3242E+01

$1.2638 \mathrm{E}+001.2065 \mathrm{E}+00$ 5.8453E-01

4.0833E+01 3.8981E+01 1.8885E+01

$19220 \quad 21 \quad 22$

1.2362E+01 3.8044E+01 1.1232E+01 3.5261E+01

$1.2459 E+001.0365 E+001.2521 E+005.6817 E-01$

4.0254E+01 3.3488E+01 4.0454E+01 1.8357E+01

$\begin{array}{lllll}14 & 15 & 16 & 17 & 18\end{array}$

3.2580E+01 2.5533E+01 3.9117E+01 1.0336E+01 6.9199E+00

1.0020E+00 1.1177E+00 9.9172E-01 1.2165E+00 8.1284E-01

3.2373E+01 3.6110E+01 3.2041E+01 3.9302E+01 2.6262E+01

$\begin{array}{lllllll}8 & 9 & 10 & 11 & 12 & 13\end{array}$

2.7549E+01 3.2546E+01 1.2436E+01 2.5278E+01 1.8951E+01 3.3448E+01

1.0752E+00 1.0027E+00 1.2582E+00 1.2760E+00 1.1249E+00 4.0190E-01

3.4737E+01 3.2394E+01 4.0649E+01 4.1227E+01 3.6343E+01 1.2985E+01

$\begin{array}{lllllll}1 & 2 & 3 & 4 & 5 & 6 & 7\end{array}$

4.3063E+01 2.7234E+01 1.2595E+01 2.7219E+01 2.7758E+01 1.1983E+01 3.4088E+01

5.9729E-01 1.0229E+00 1.1730E+00 8.5417E-01 1.2380E+00 1.3372E+00 6.7321E-01

1.9298E+01 3.3049E+01 3.7898E+01 2.7597E+01 3.9997E+01 4.3203E+01 2.1751E+01

Fig. 4-2. MOX zone. Assembly burnup, relative power and temperature drop for control rod ejection calculation 
Russian Research Center "Kurchatov Institute"

Spatial Kinetics Calculations of MOX Fuelled Core. Variant 22

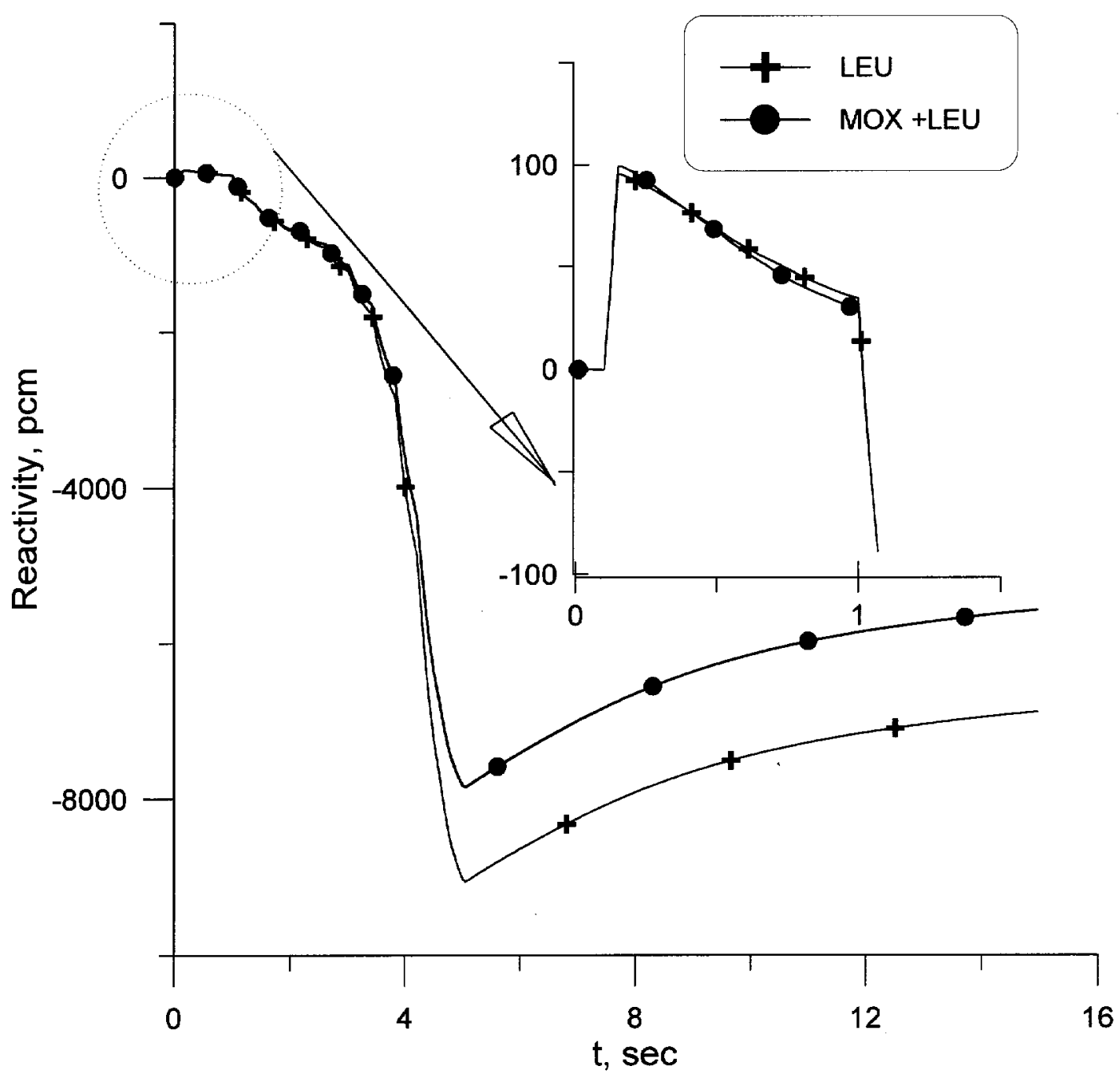

Fig. 4-3. Reactivity. Central Control Rod Ejection 
Russian Research Center "Kurchatov Institute"

Spatial Kinetics Calculations of MOX Fuelled Core. Variant 22

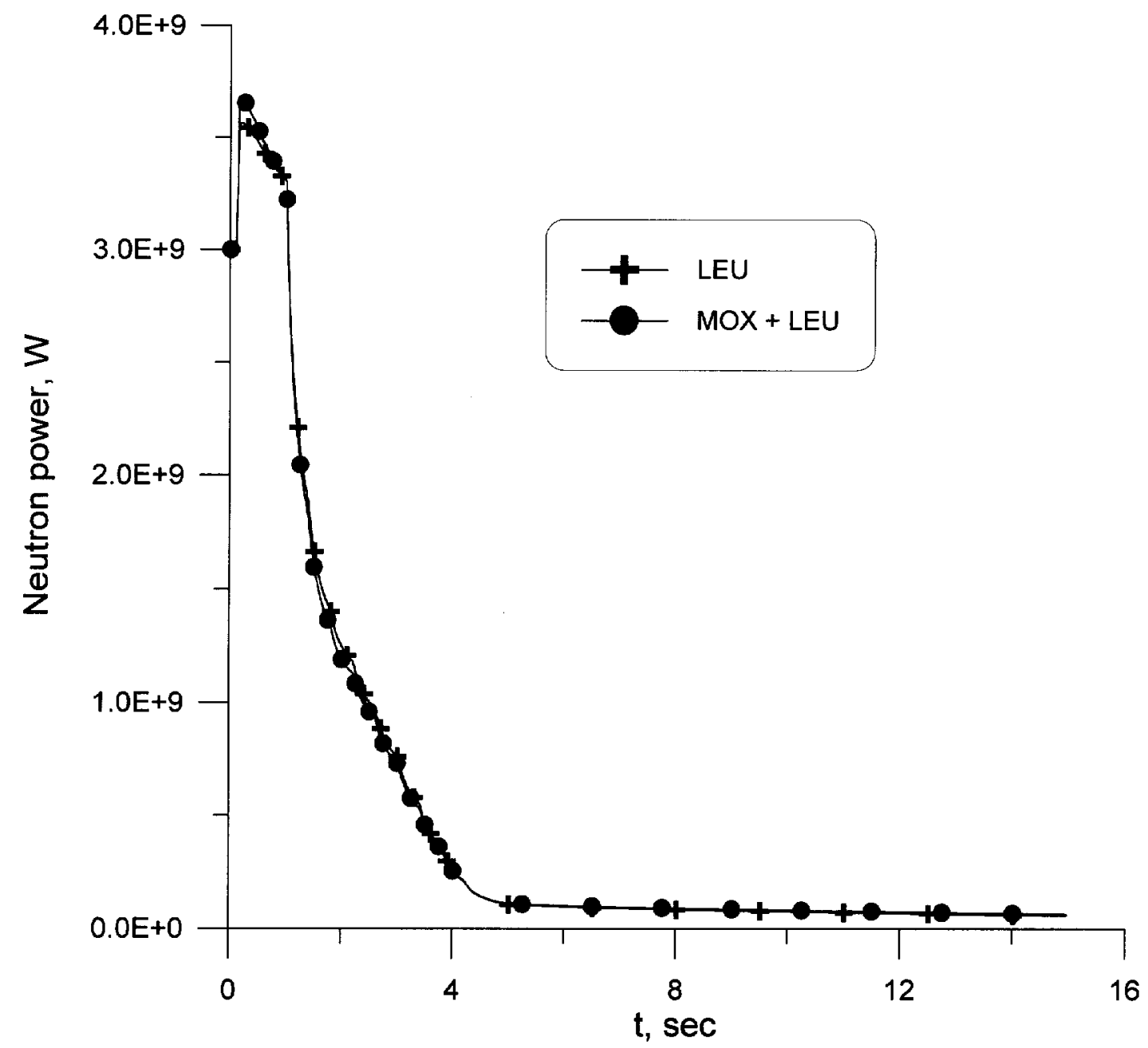

Fig. 4-4. Neutron Power. Central Control Rod Ejection 
Russian Research Center "Kurchatov Institute"

Spatial Kinetics Calculations of MOX Fuelled Core. Variant 22

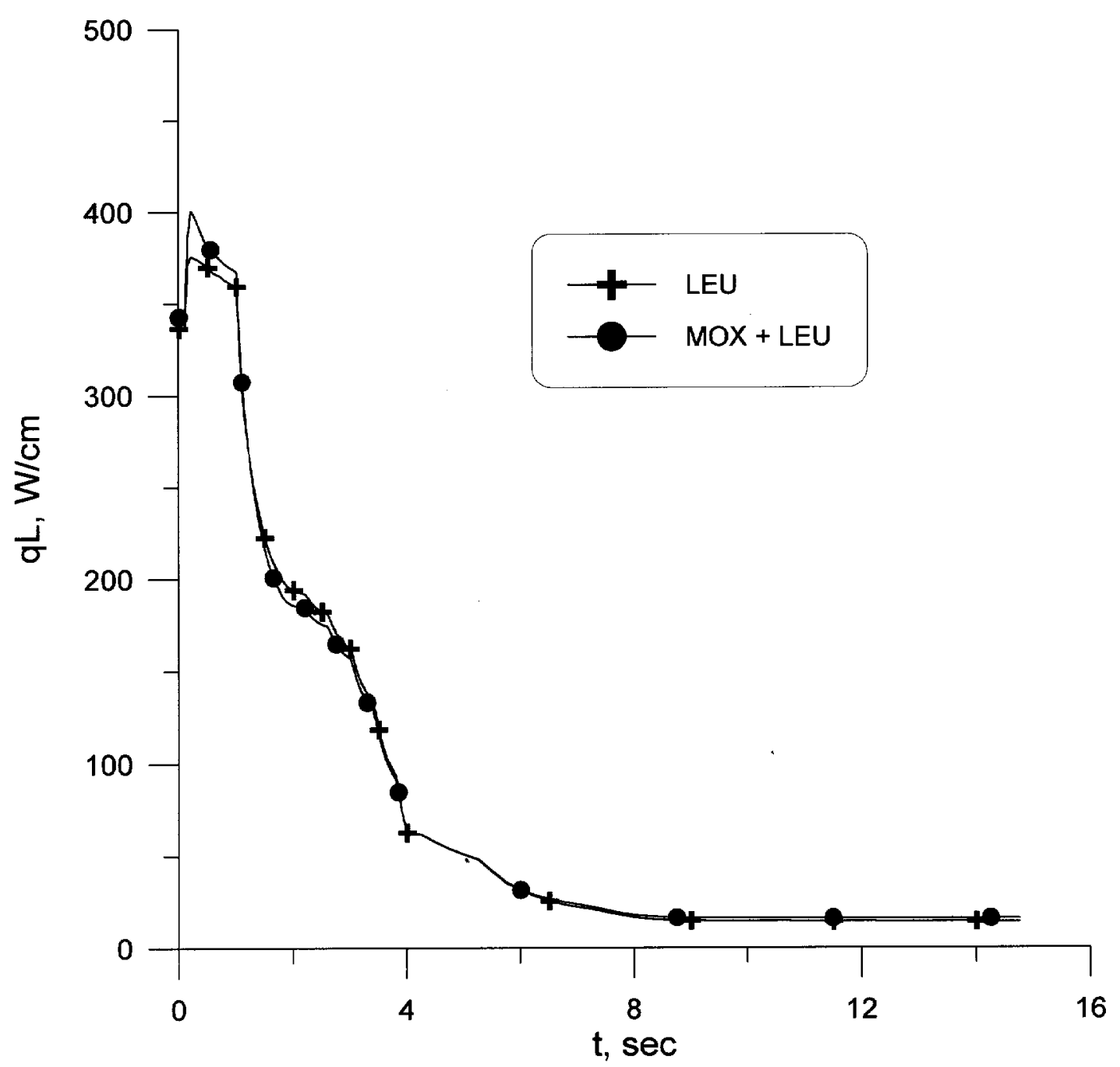

Fig. 4-5. Maximal Neutron Linear Power. Central Control Rod Ejection 
Russian Research Center "Kurchatov Institute"

Spatial Kinetics Calculations of MOX Fuelled Core. Variant 22

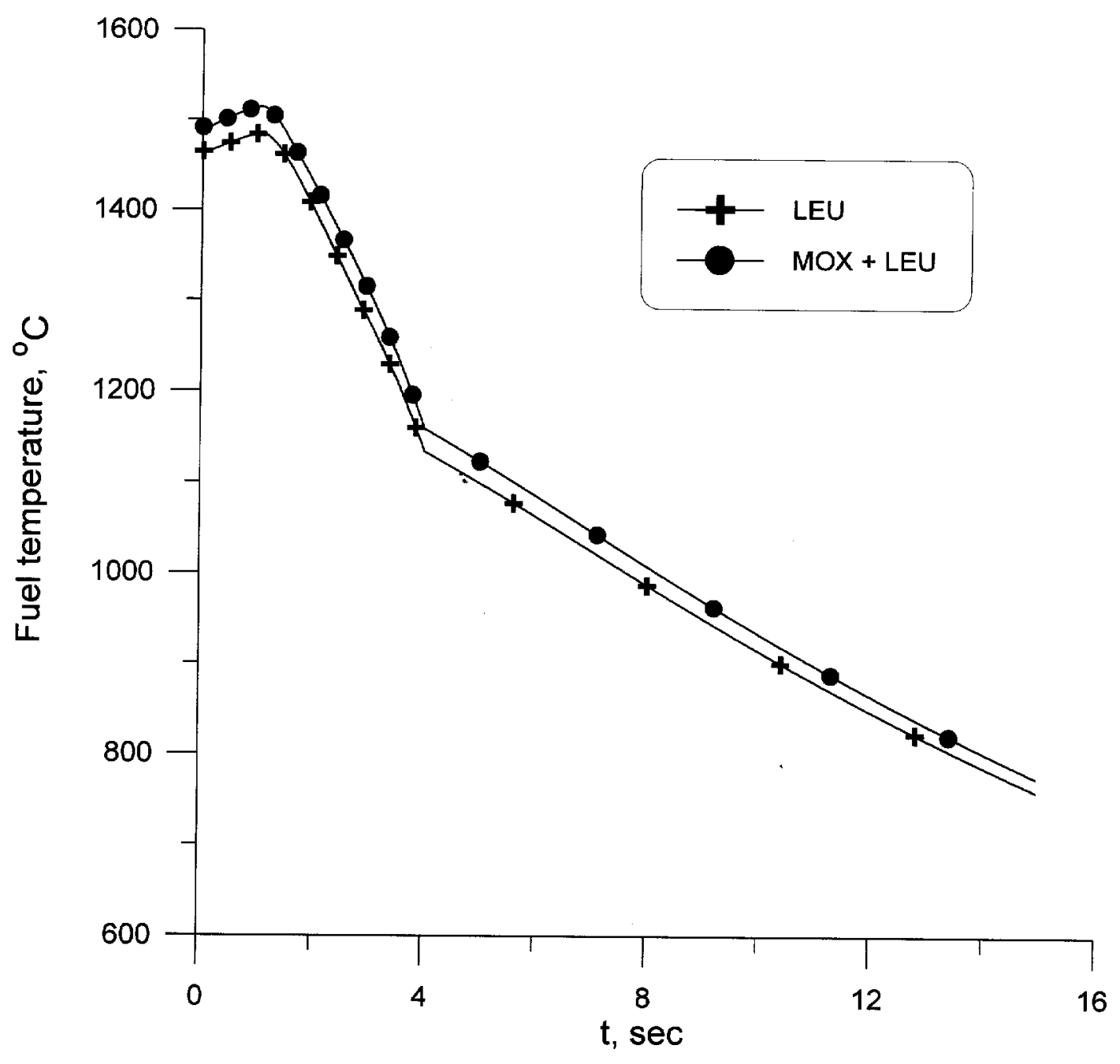

Fig. 4-6. Maximal Fuel Temperature. Central Control Rod Ejection 
Russian Research Center "Kurchatov Institute"

Spatial Kinetics Calculations of MOX Fuelled Core. Variant 22

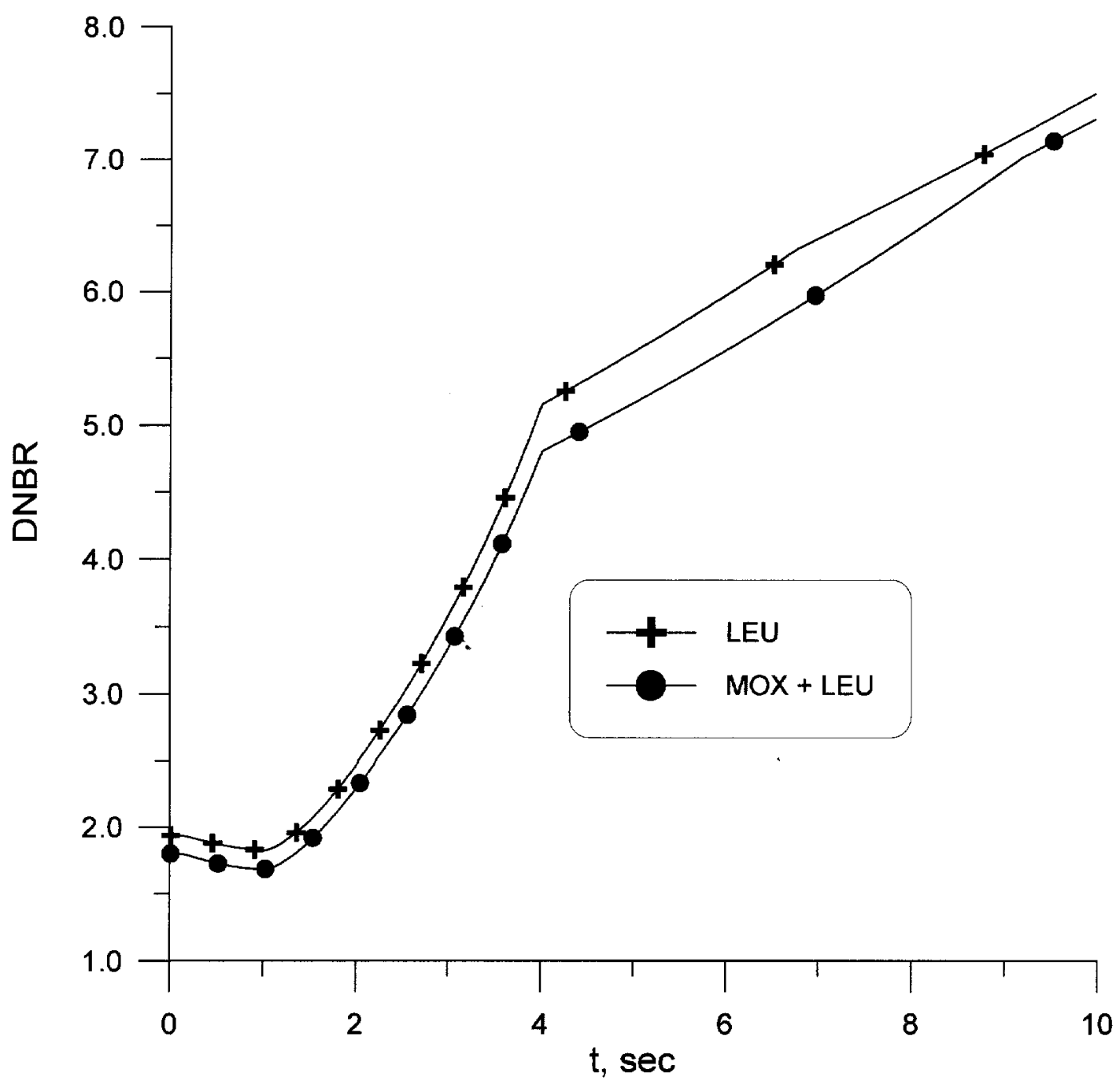

Fig. 4-7. Minimal DNBR. Central Control Rod Ejection 
Russian Research Center "Kurchatov Institute"

Spatial Kinetics Calculations of MOX Fuelled Core. Variant 22

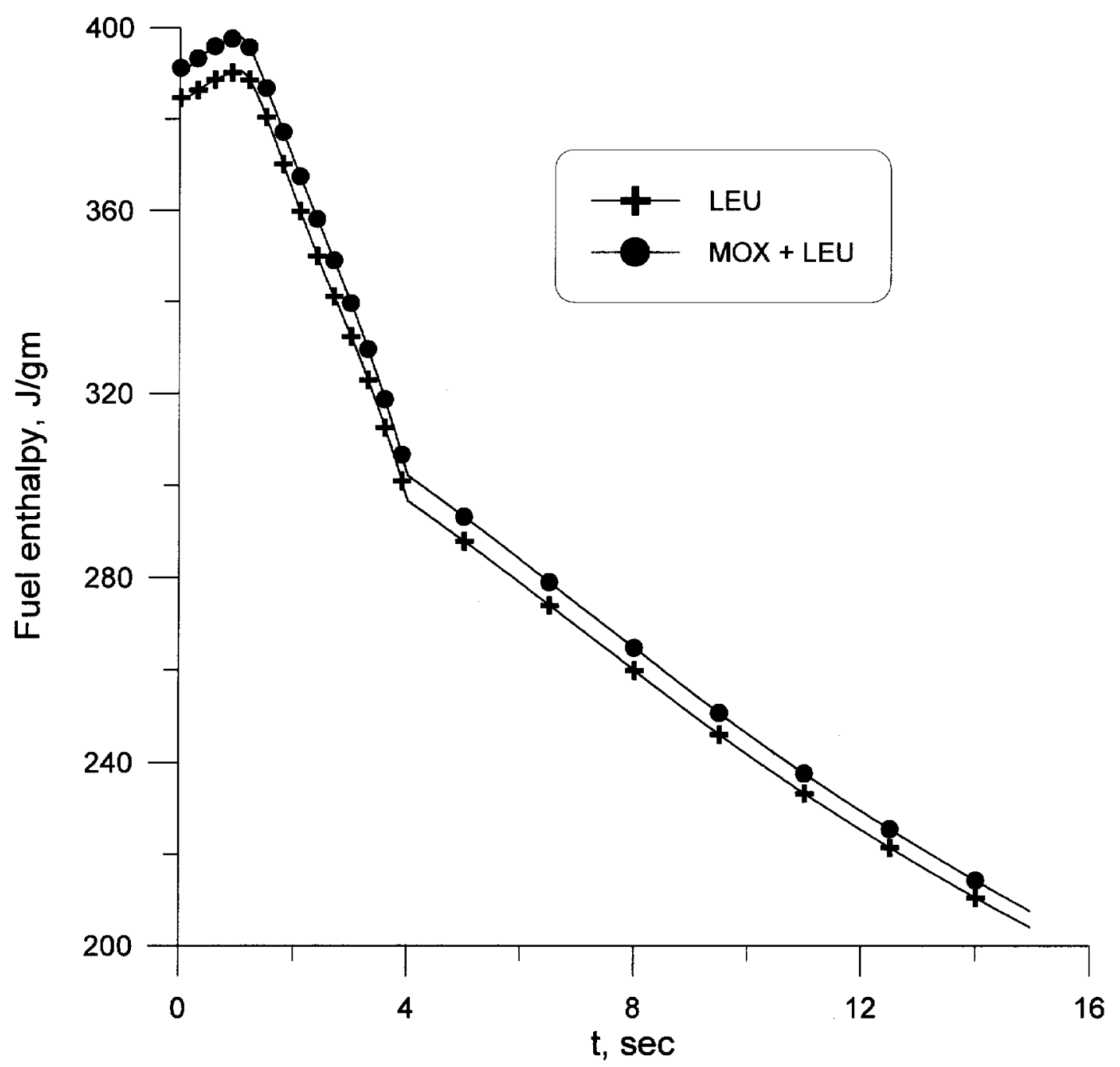

Fig. 4-8. Maximal Fuel Enthalpy. Central Control Rod Ejection 


\section{Russian Research Center "Kurchatov Institute" \\ Spatial Kinetics Calculations of MOX Fuelled Core. Variant 22}

\section{Core Cooling in Case of Steam Line Rupture}

5.1. Process being investigated: Overcooling of the reactor core caused by steam line rupture and non-closure of steam generator stop valve.

5.2. Initial state of the core:

- EOC for equilibrium refueling regime.

- $\mathrm{W}=\mathrm{Wnom}$.

- Inlet pressure of coolant - 16.4 MPa.

- Coolant flow rate $-84000 \mathrm{~m}^{3} / \mathrm{h}$.

- Position of control rods regulating bank - 70\% from the core bottom.

- Xe eq (Wnom) and Sm eq

\subsection{Scenario of transient}

Accident with steam line rupture in one of the loops between the steam generator and steam generator stop valve, with the power unit de-energized. Accident sequence is shown in Table 5.1 .

Table 5-1. Accident sequence

\begin{tabular}{|c|l|}
\hline Time, sec & \multicolumn{1}{c|}{ Events and parameters } \\
\hline 0.0 & $\begin{array}{l}\text { The reactor plant operates at Wnom; parameters of primary } \\
\text { and secondary circuits are within the permissible limits with } \\
\text { allowance for deviations. }\end{array}$ \\
\hline 0.3 & $\begin{array}{l}\text { The steam line is depressurized, in the period from 0.3s to } \\
0.6 \mathrm{~s} \text { the rupture cross section increases linearly up to the full } \\
\text { steam line cross section. }\end{array}$ \\
\hline 2.6 & $\begin{array}{l}\text { Scram is actuated (all rods except for the most effective). } \\
\text { Duration of the rod drop is 4 sec. }\end{array}$ \\
\hline 20 & $\begin{array}{l}\text { BRUAs operate, the pressure in three intact SG is maintained } \\
\text { within the rated limits. }\end{array}$ \\
\hline
\end{tabular}

These events lead to variations of core parameters that are shown in Table 5.2. The temperature values are calculated under assumption of the absence of coolant mixing between the loops. Assembly numbers in the one fourth part of the core connected with ruptured steam line are: 4-6, 11-15, 21-25, 31-36, 43-48, 55-61, 69-75, 82. Fig 5.1 shows the changes in the inlet temperature in the overcooled fourth part of the core and other assemblies. 
Russian Research Center "Kurchatov Institute"

Spatial Kinetics Calculations of MOX Fuelled Core. Variant 22

\section{Table 5-2. Variation of Core Parameters in the Accident with Steam Line Rupture and Power Unit de-Energized}

\begin{tabular}{|c|c|c|c|c|}
\hline \multirow{3}{*}{ Time. sec } & \multicolumn{4}{|c|}{ Reactor coolant system parameters } \\
\cline { 2 - 3 } & \multicolumn{2}{|c|}{$\mathrm{t}_{\text {entry, }}{ }^{\circ} \mathrm{C}$} & $\begin{array}{c}\text { Flow rate through the } \\
\text { core. } \mathrm{G} / \mathrm{G}_{\text {nom }}\end{array}$ & Pressure, MPa \\
& \multicolumn{2}{|c|}{} \\
\cline { 2 - 3 } & $\mathrm{t}_{1 / 4 \text { core }}$ & $\mathrm{t}_{3 / 4}$ core & & \\
\hline 0 & 287 & 287 & 1 & 16.4 \\
\hline 10 & 272 & 280 & 0.8 & 14.5 \\
\hline 20 & 248 & 270 & 0.6 & 13.9 \\
\hline 30 & 229 & 259 & 0.45 & 13.6 \\
\hline 40 & 220 & 248 & 0.35 & 13.4 \\
\hline 50 & 225 & 246 & 0.3 & 13.4 \\
\hline
\end{tabular}

\subsection{Results of calculations.}

The calculation results of dynamical processes are shown in Figs. 5.1-5.7, Figs. 5.3-5.6 present the characteristics of «hot» channel with sampling all over the core. Fig. 5.7 presents the power of assembly number 24 located in the overcooled fourth part of the core, and power of assembly number 129 .

The analysis of Figs. 5.1 - 5:7 shows that for the accident considered the MOXzone proved to be more dangerous. However this difference is very small. 


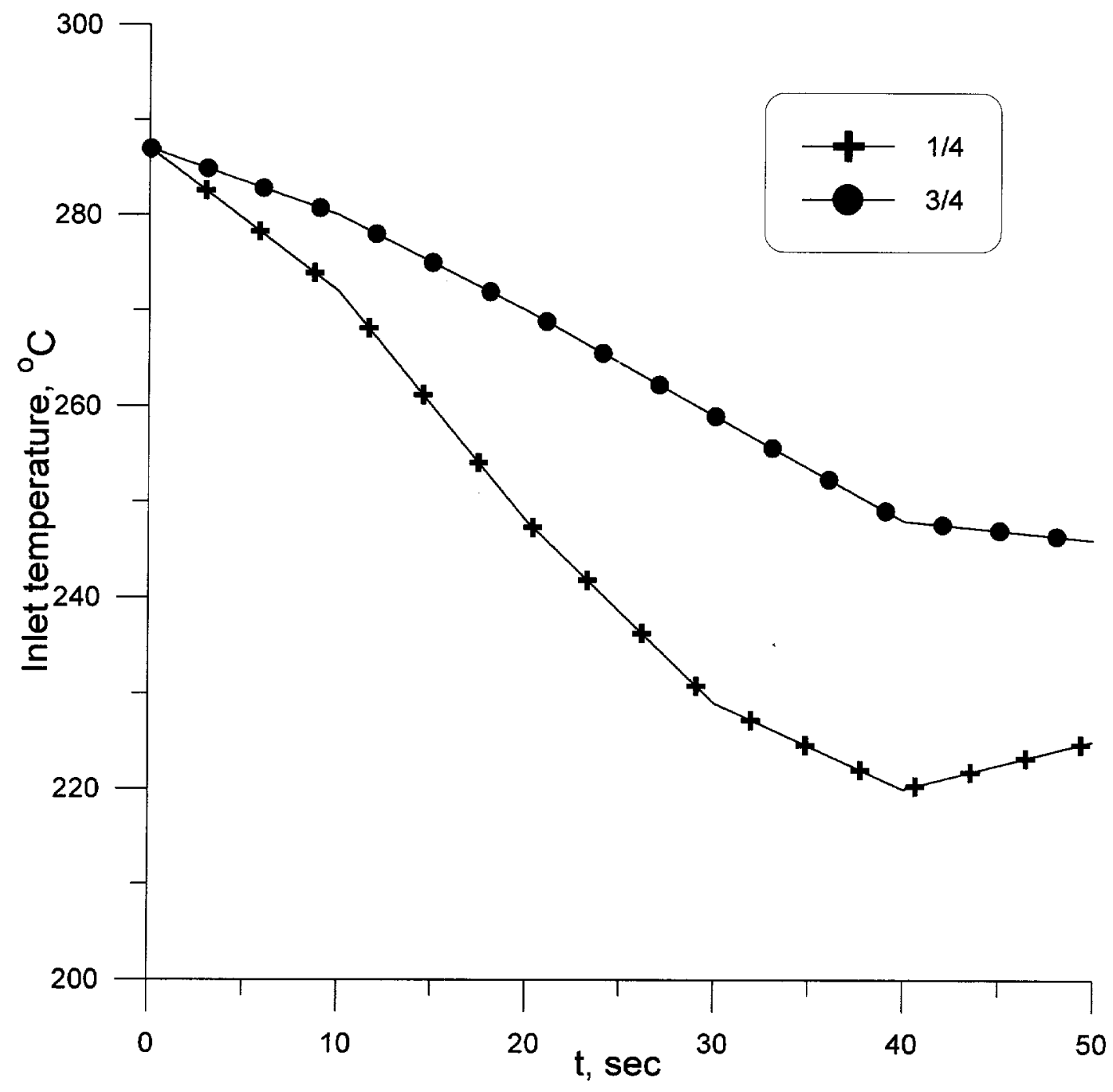

Fig. 5-1. Inlet Temperature in Different Parts of the Core. Partial Core Overcooling 
Russian Research Center "Kurchatov Institute" Spatial Kinetics Calculations of MOX Fuelled Core. Variant 22

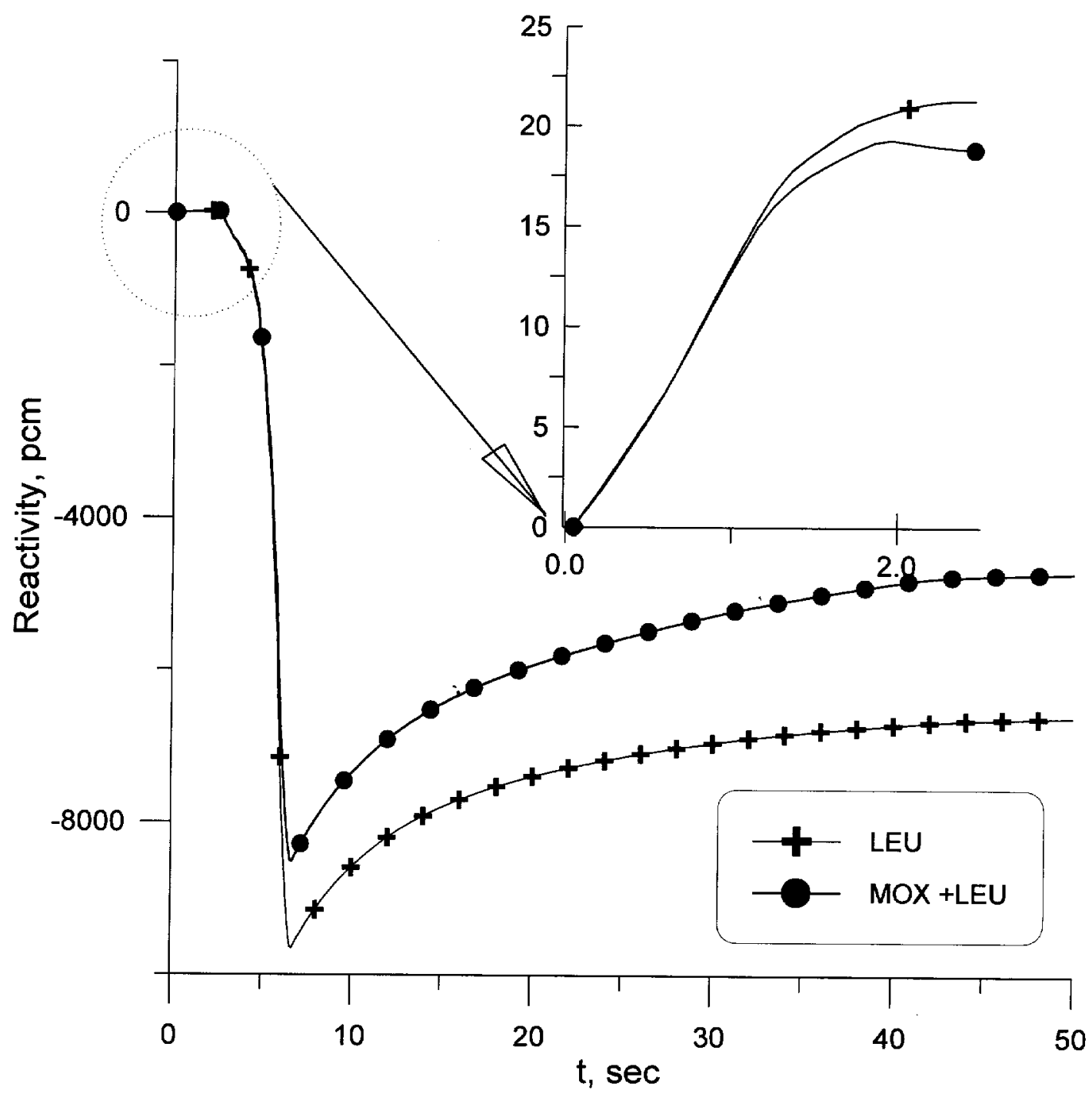

Fig. 5-2. Reactivity. Partial Core Overcooling 
Russian Research Center "Kurchatov Institute"

Spatial Kinetics Calculations of MOX Fuelled Core. Variant 22

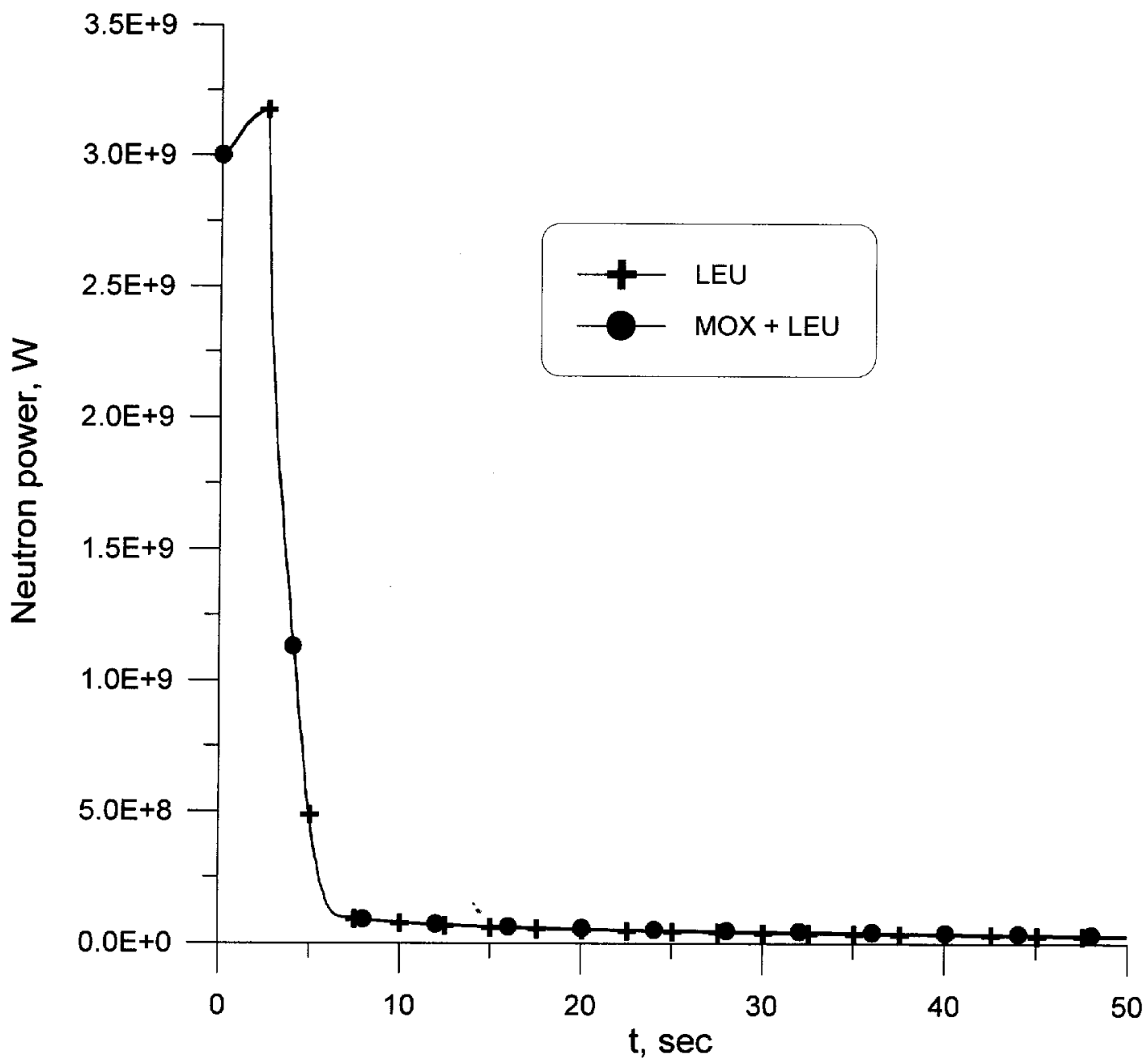

Fig. 5-3. Neutron Power. Partial Core Overcooling 
Russian Research Center "Kurchatov Institute"

Spatial Kinetics Calculations of MOX Fuelled Core. Variant 22

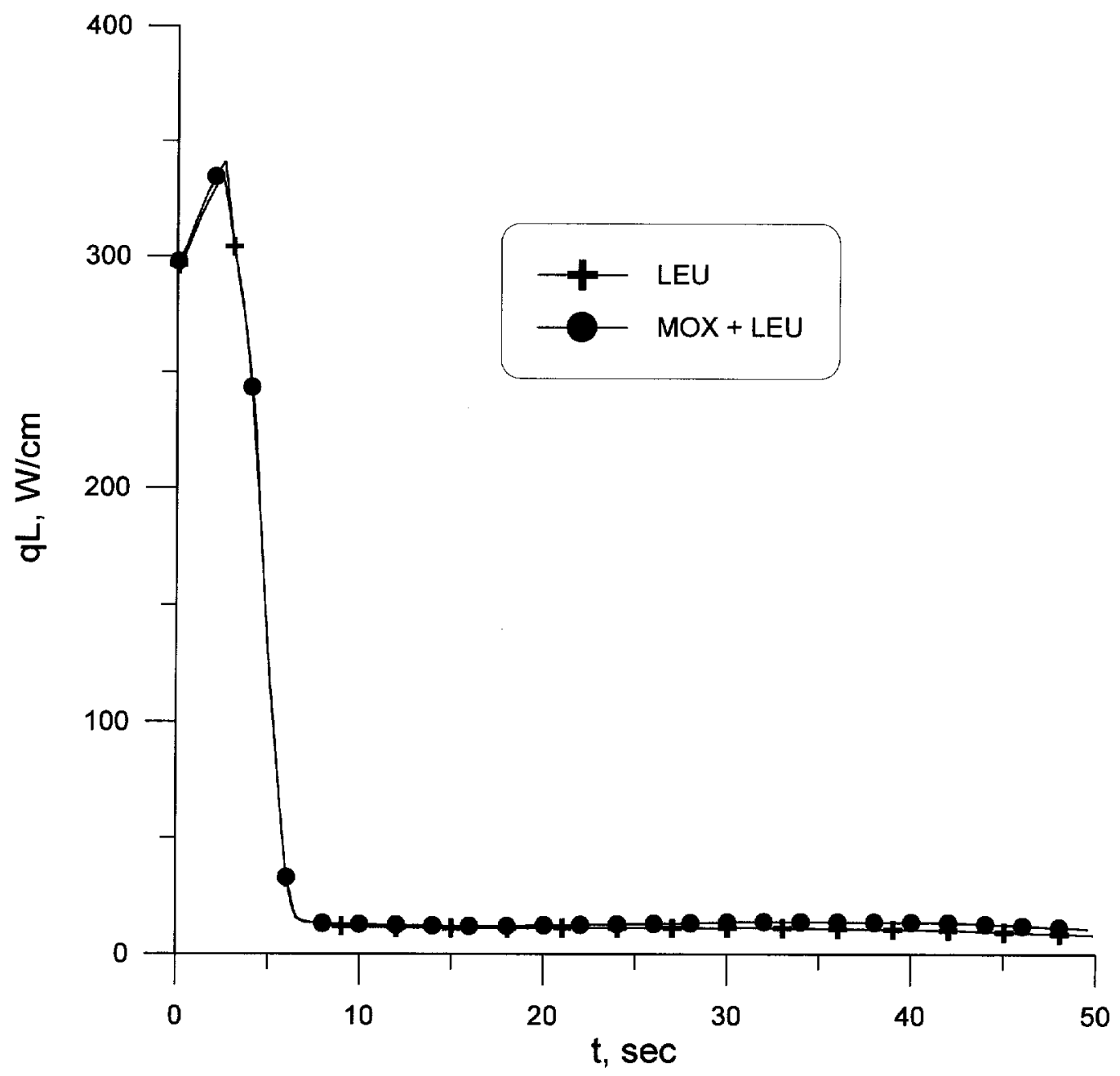

Fig. 5-4. Maximal Neutron Linear Power. Partial Core Overcooling 
Russian Research Center "Kurchatov Institute"

Spatial Kinetics Calculations of MOX Fuelled Core. Variant 22

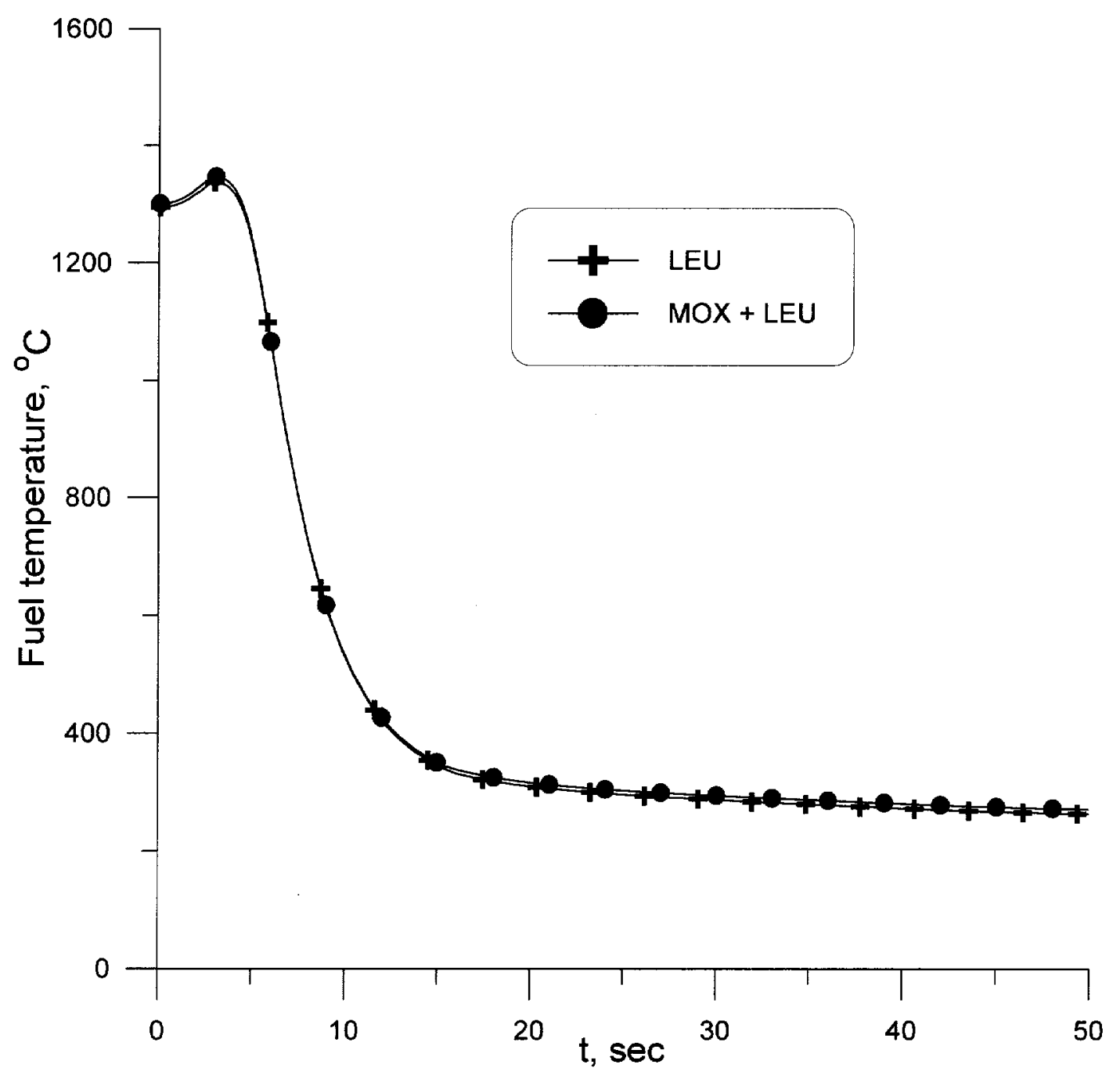

Fig. 5-5. Maximal Fuel Temperature. Partial Core Overcooling 
Russian Reisearch Center "Kurchatov Institute"

Spatial Kinetics Calculations of MOX Fuelled Core. Variant 22

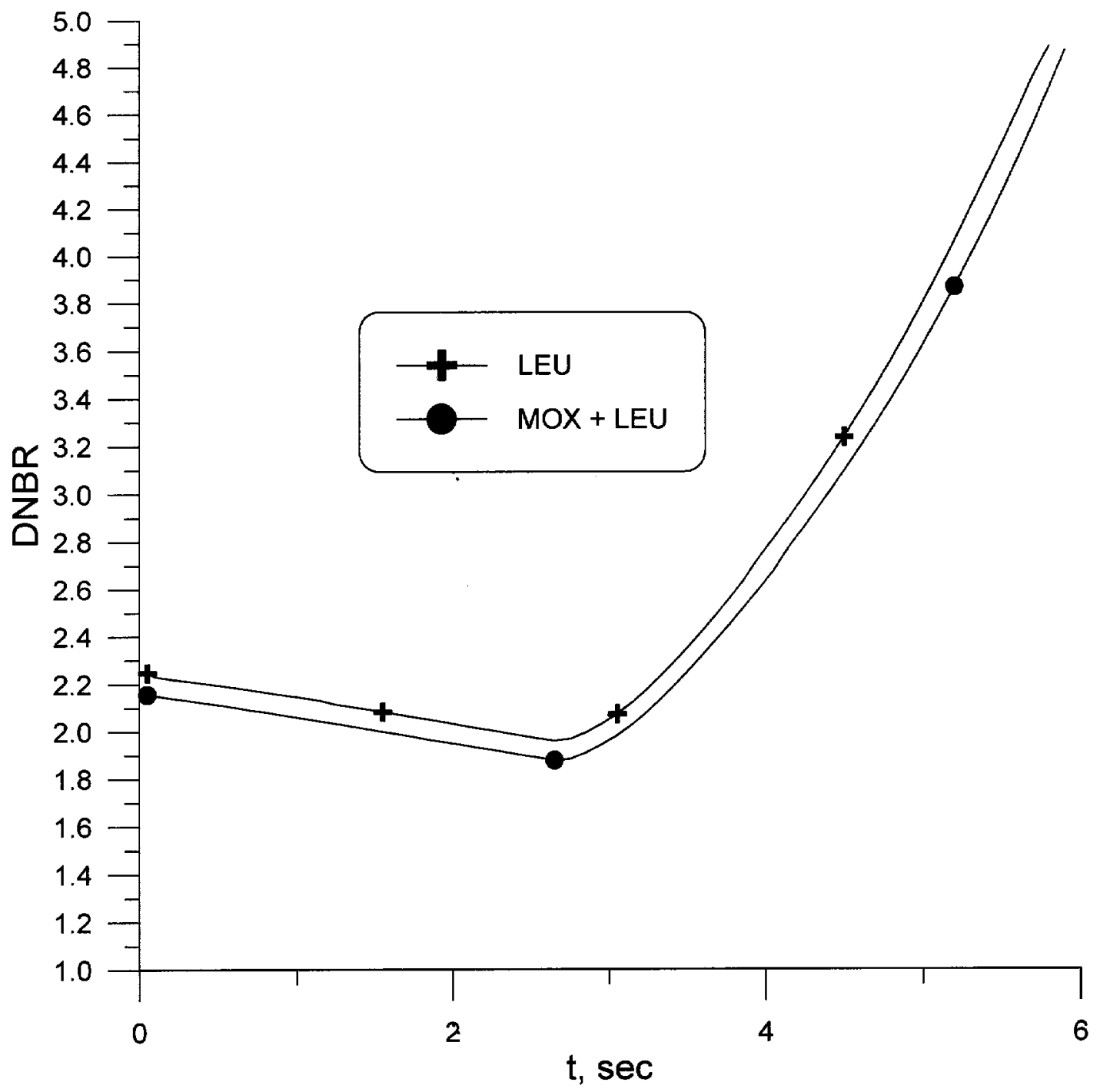

Fig. 5-6. Minimal DNBR. Partial Core Overcooling 
Russian Research Center "Kurchatov Institute"

Spatial Kinetics Calculations of MOX Fuelled Core. Variant 22

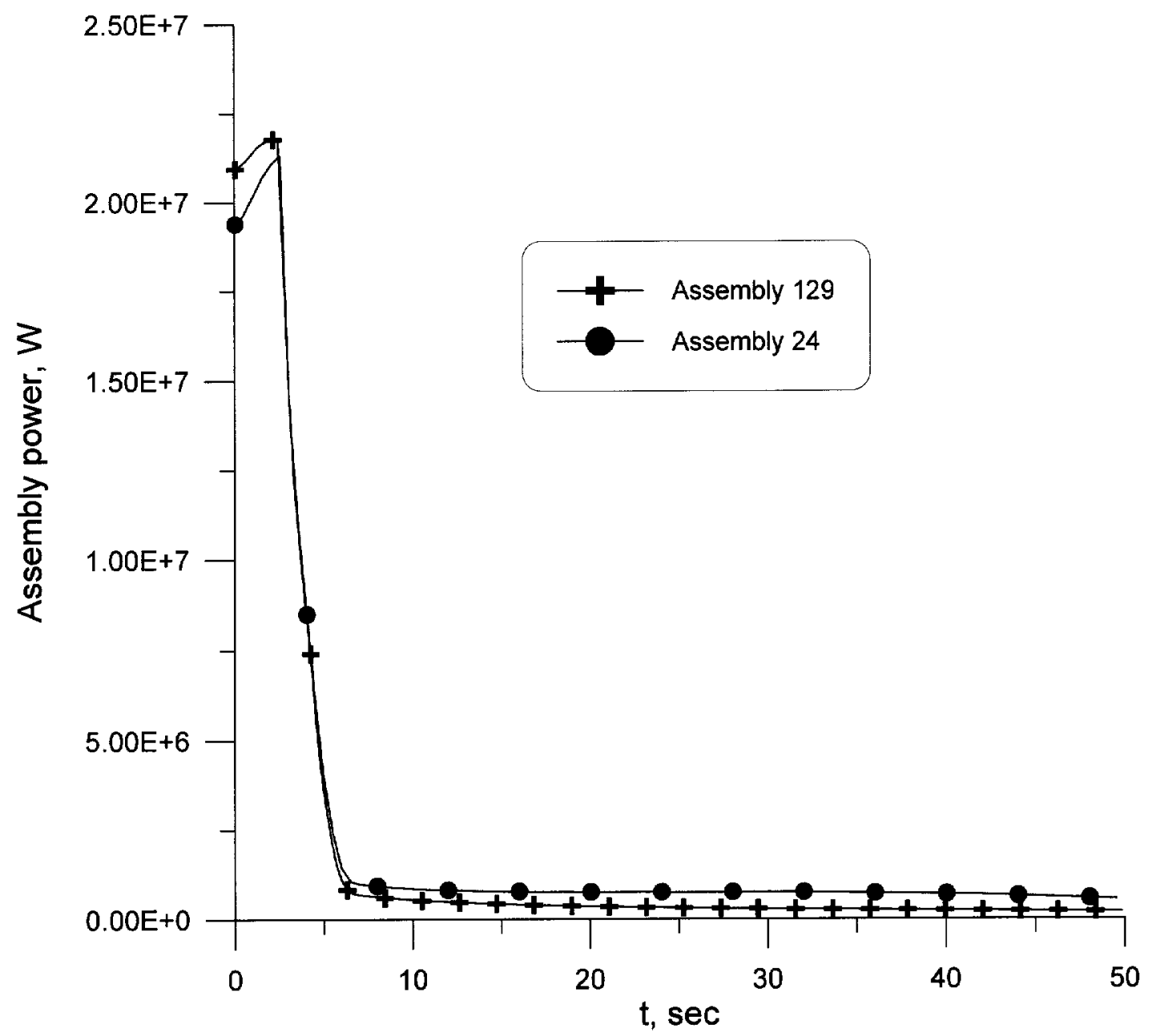

Fig. 5-7. Assembly Power. Partial Core Overcooling. MOX + LEU 


\section{The Boron Dilution of Coolant in a Part of the VVER-1000 Core}

6.1 Process being investigated: The boron dilution of coolant in part of the VVER-1000 core caused by penetration of the distillate slug into the core at start up of non-working loop.

\subsection{Initial state of the core:}

- BOC for equilibrium refueling regime.

- $\mathrm{W}=0.66 \mathrm{Wnom}$.

- Three main circulating pumps are working, coolant flow rate $-75 \%$ of nominal value $84000 \mathrm{~m}^{3} / \mathrm{h}$.

- Position of control rods regulating bank - $80 \%$ from the core bottom.

- Xe eq (Wnom) and Sm eq.

\subsection{Scenario of transient.}

At initial time point $(4.0 \mathrm{sec})$ the fourth main circulating pump is assumed to be switched on. The flow rate of this pump changes linearly during $30 \mathrm{sec}$ from $0 \%$ to $100 \%$ of nominal value $\left(21000 \mathrm{~m}^{3} / \mathrm{h}\right)$.

At time point of $6.0 \mathrm{sec}$ the distillate slug comes to the core inlet.

When the reactor power exceeds $110 \%$ of initial value, the scram activates. Duration of the rod drop is 4 sec.

Simultaneously with activation of the scram, the most effective control rod located in the cell 58 of the $5^{\text {th }}$ bank is stuck at its upper position.

It is assumed that full amount of coolant from the activated loop comes into the one-fourth part of the core (see below Fig. 6-1).

Within this quarter of the core the distillate and coolant coming from other loops are fully mixed.

The boric acid concentration at inlet of this quarter $\mathrm{C}(\mathrm{t})$ changes according to the following dependence:

$$
\begin{cases}C(t)=C_{H} ; & \mathrm{t}<\tau_{1} \\ C(t)=\frac{3\left(1-\frac{t}{\tau}\right)}{3+\frac{t}{\tau}} C_{H} ; & \\ C(t)=0.0 ; & \mathrm{t}>\tau\end{cases}
$$

where $\mathrm{C}_{\mathrm{H}}$ - critical boric acid concentration for initial state;

$\tau_{1}$ - time point when the distillate slug enters into the core $(4 \mathrm{sec})$;

$\tau$ - end of startup period for the $4^{\text {th }}$ pump (34 sec). 


\section{Russian Research Center "Kurchatov Institute" Spatial Kinetics Calculations of MOX Fuelled Core. Variant 22}

Concentration of boric acid in other $3 / 4$ part of the core does not change during the transient.

\subsection{Main calculation results.}

Fig. 6-2 shows the change in the boric acid concentration in the typical fuel assembly of sector 1 .

The calculation results of dynamical process are given in Figs. 6-3 - 6-9, Figs. 6-5 - 6-8 show the "hot" channel (sampling is made over the whole core).

As far as the neutron power is concerned, the first downward kink of the curve is accounted for by the drop of safety control rods, the second - for the Doppler effect.

The analysis of Figs. 6-3 - 6-9 shows that for the accident considered the MOXzone proved to be more dangerous. However this difference is not very important. The short-time DNB both in LEU and MOX + LEU cores is possible. 
Russian Research Center "Kurchatov Institute"

Spatial Kinetics Calculations of MOX Fuelled Core. Variant 22

Fig. 6-1. Numbers of Fuel Assemblies in the Quarter of the Core

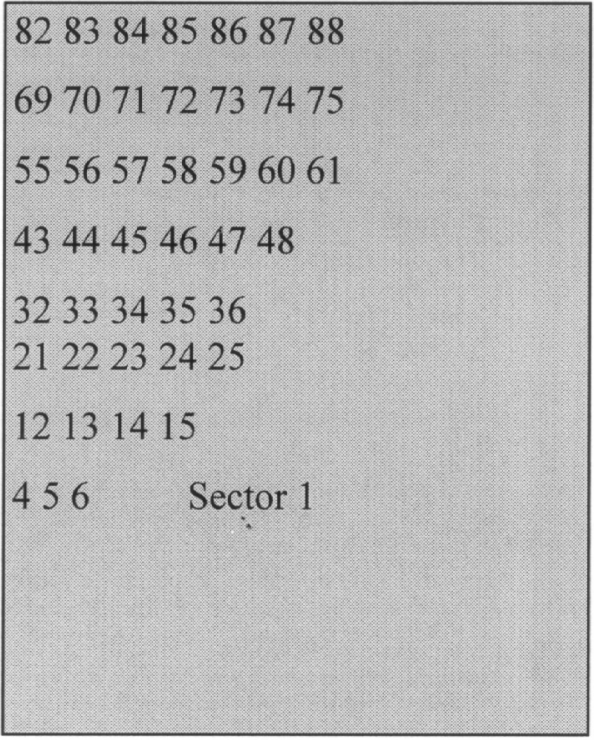


Russian Research Center "Kurchatov Institute"

Spatial Kinetics Calculations of MOX Fuelled Core. Variant 22

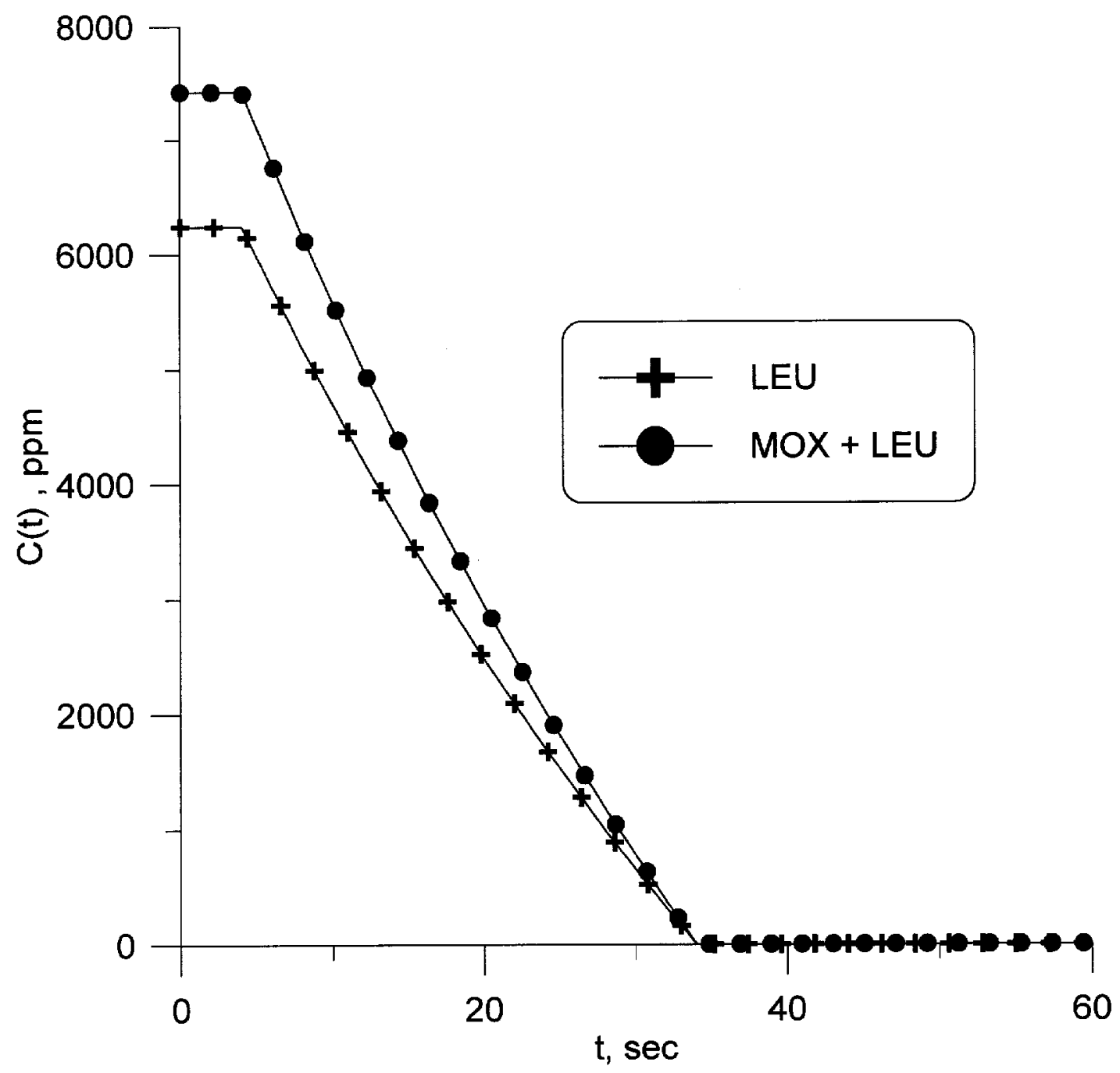

Fig. 6-2. Concentration of Boron Acid. Loop Put into Operation \& Boron Dilution 
Russian Research Center "Kurchatov Institute"

Spatial Kinetics Calculations of MOX Fuelled Core. Variant 22

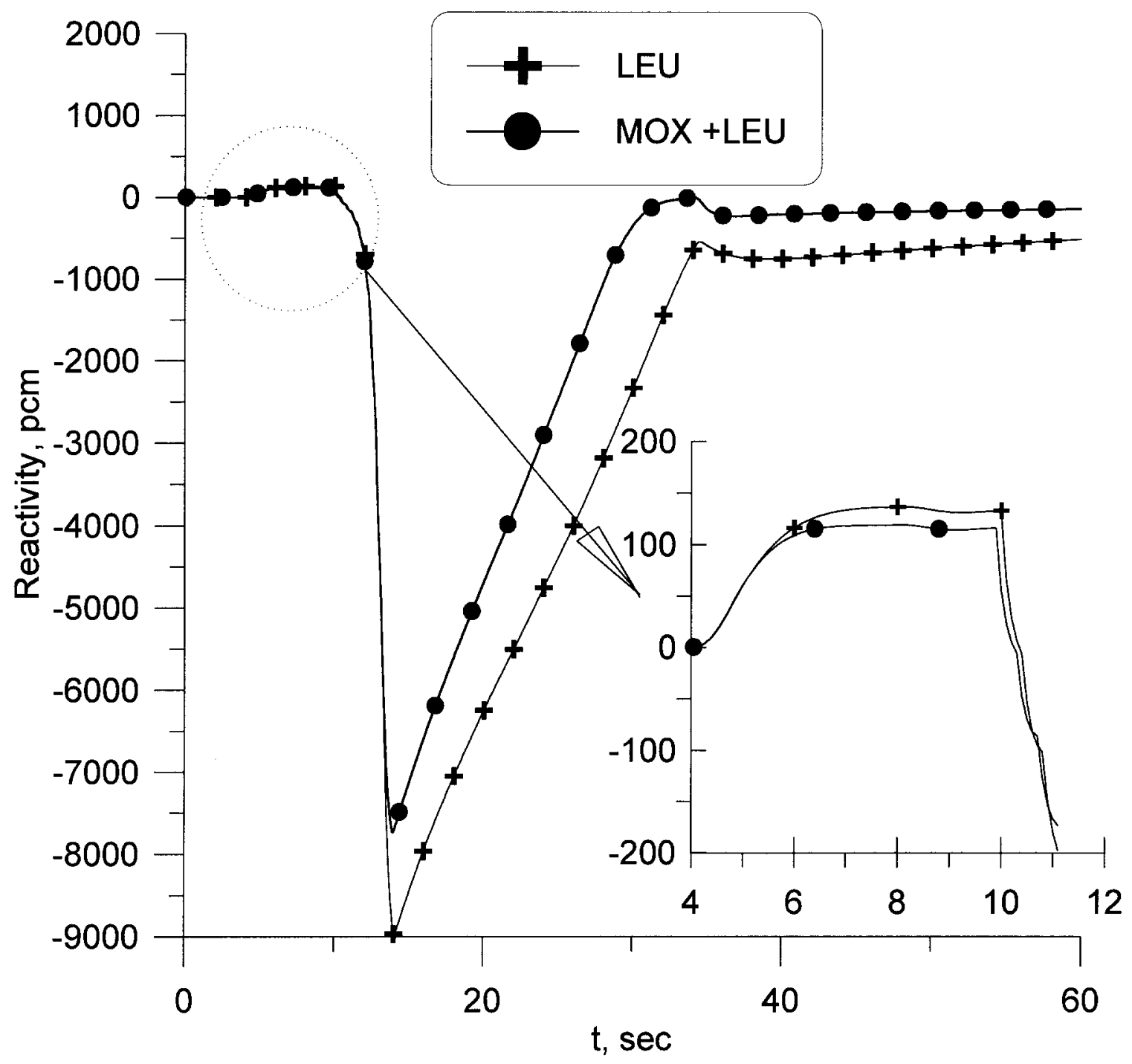

Fig. 6-3. Reactivity. Loop Put into Operation \& Boron Dilution 


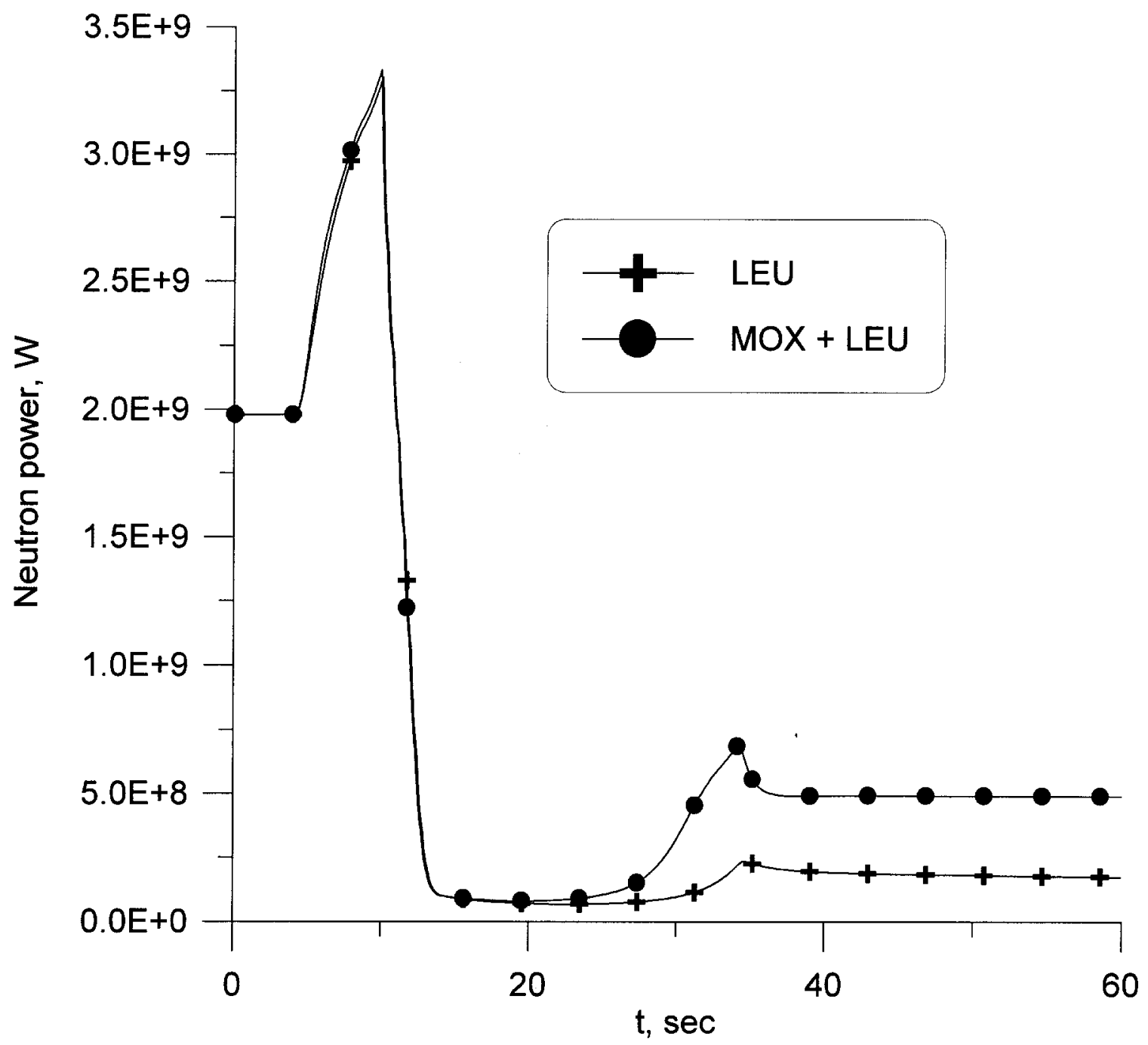

Fig. 6-4. Neutron Power. Loop Put into Operation \& Boron Dilution 


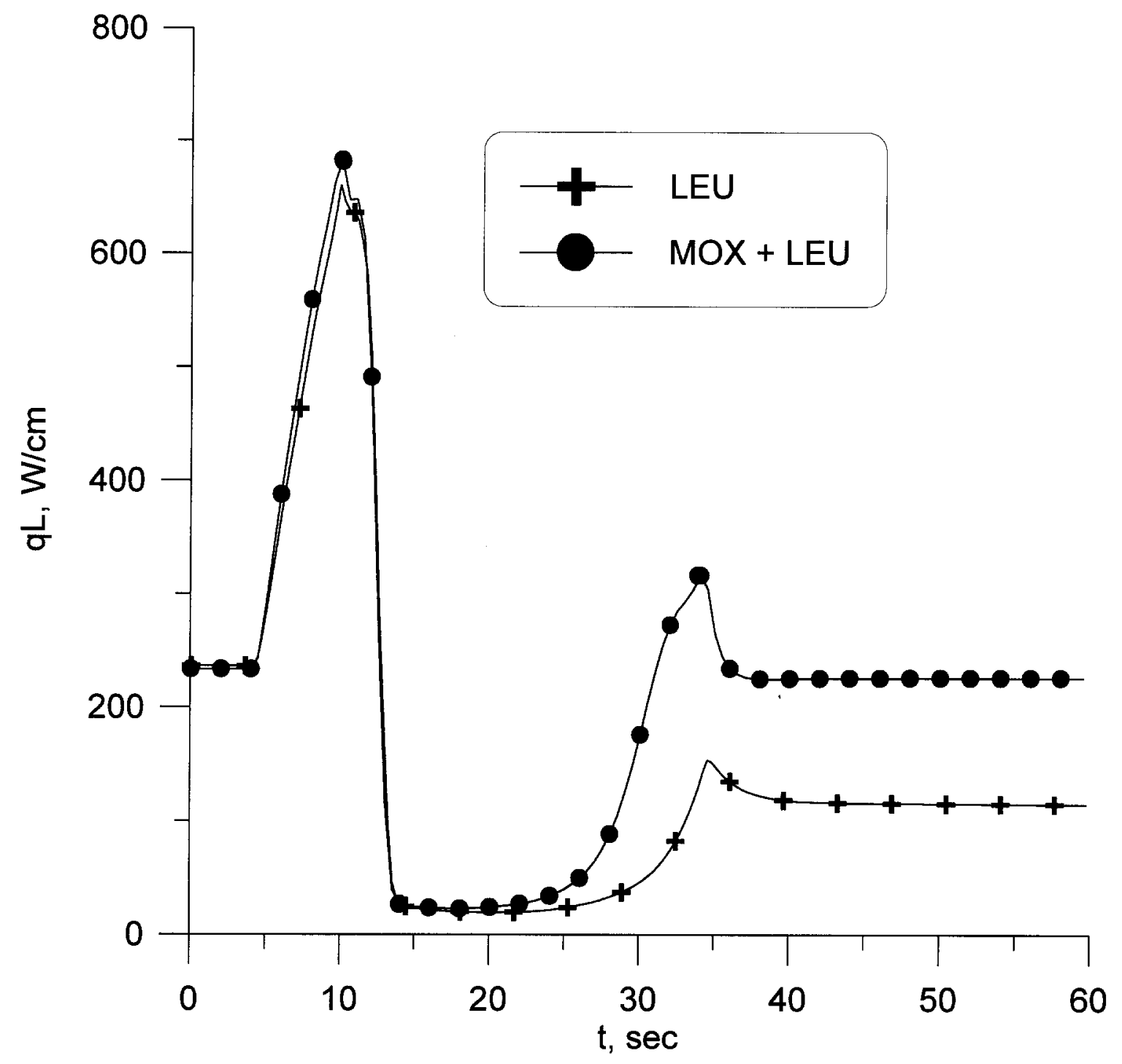

Fig. 6-5. Maximal Neutron Power. Loop Put into Operation \& Boron Dilution 
Russian Research Center "Kurchatov Institute"

Spatial Kinetics Calculations of MOX Fuelled Core. Variant 22

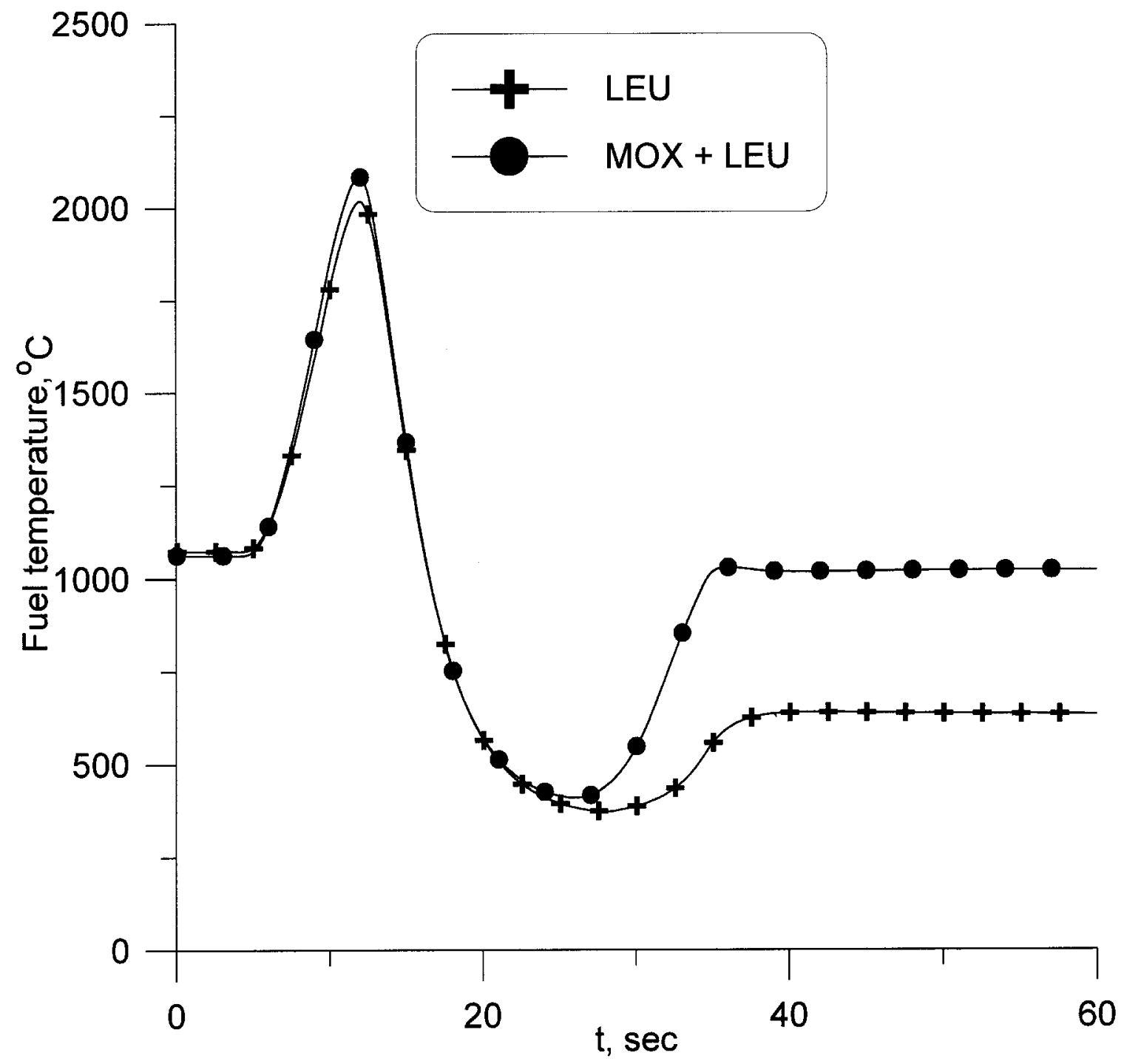

Fig. 6-6. Maximal Fuel Temperature. Loop Put into Operation \& Boron Dilution 


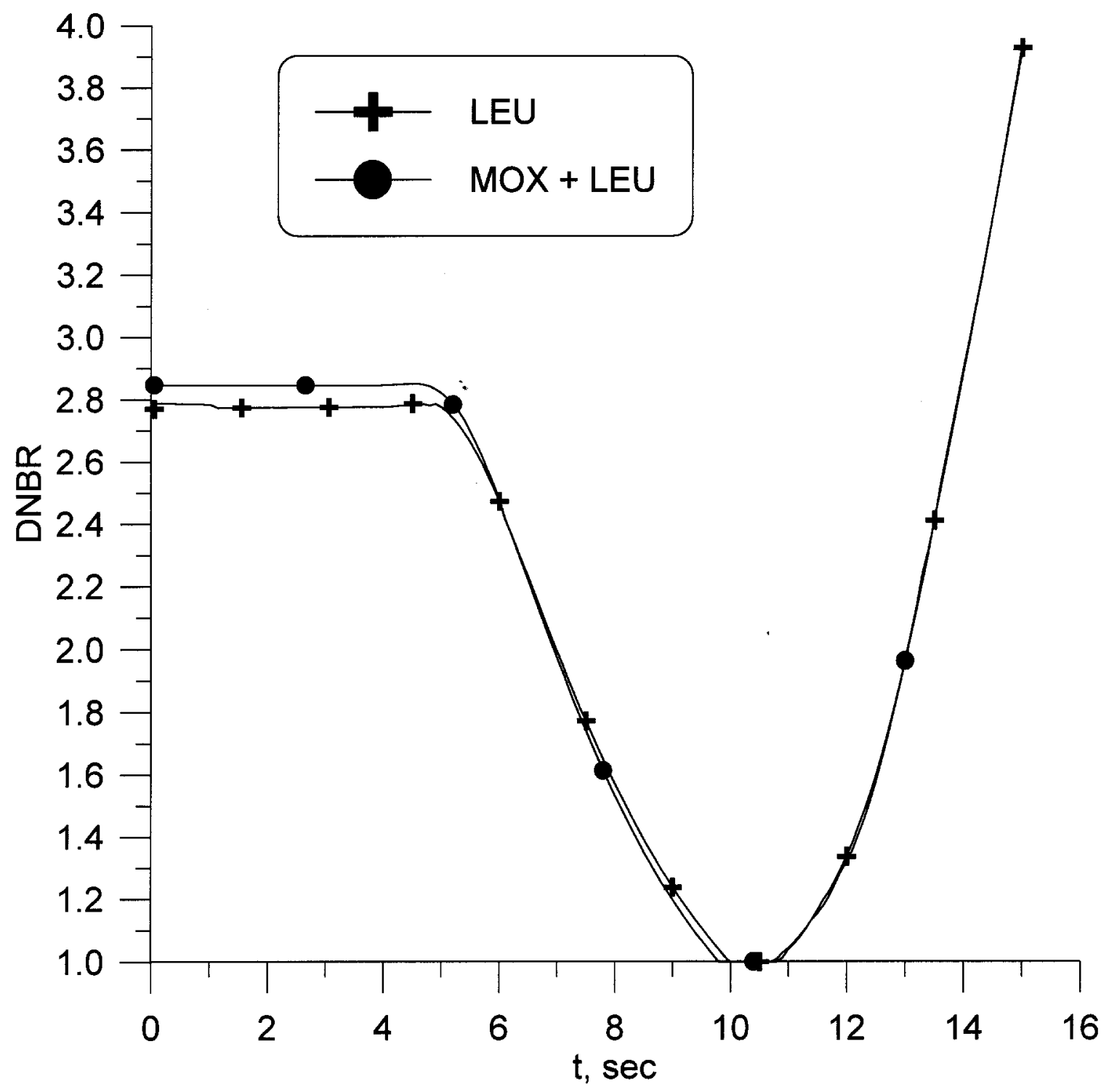

Fig. 6-7. Minimal DNBR. Loop Put into Operation \& Boron Dilution 


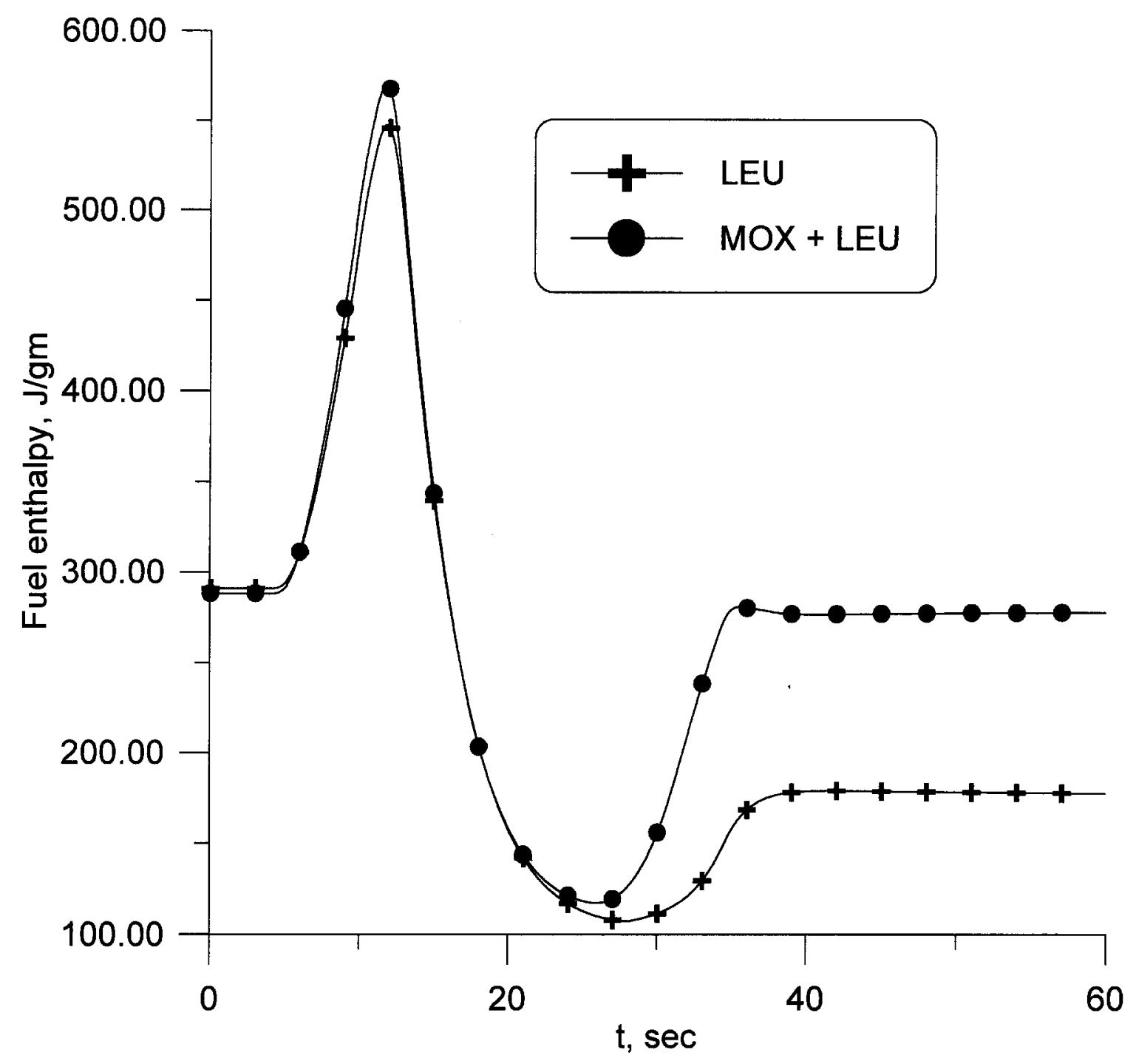

Fig. 6-8. Maximal Fuel Enthalpy. Loop Put into Operation \& Boron Dilution 
Russian Research Center "Kurchatov Institute"

Spatial Kinetics Calculations of MOX Fuelled Core. Variant 22

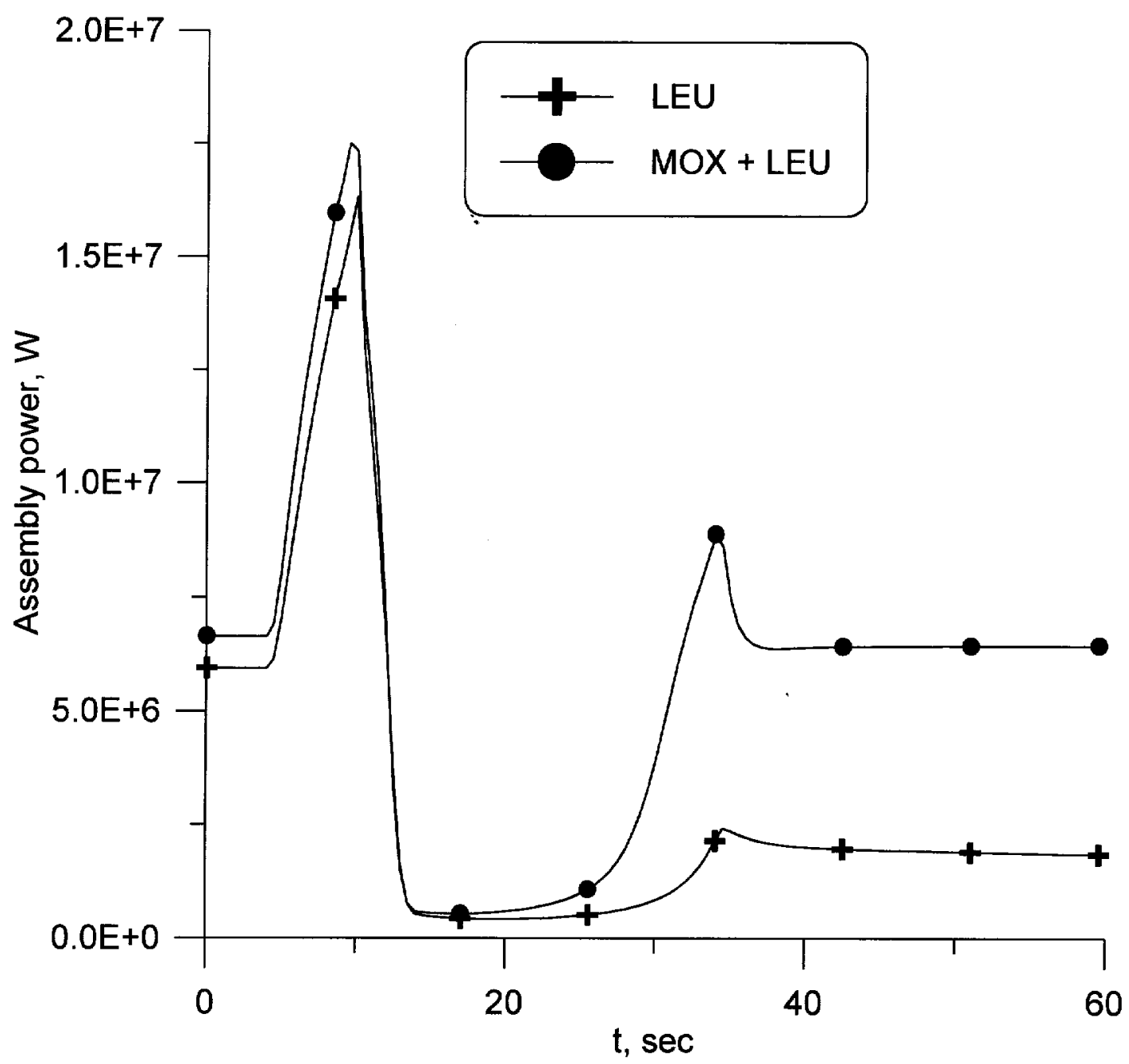

Fig. 6-9. Power of Assembly N 4. Loop Put into Operation \& Boron Dilution 
Russian Research Center "Kurchatov Institute" Spatial Kinetics Calculations of MOX Fuelled Core. Variant 22

\section{CONCLUSION}

The analysis of results of the three dynamic problems solution allows to conclude, that their solution with the help of different codes will help to execute verification of codes, which one in further will be used for modelling of the transition and emergency modes of VVER operation.

These results obtained by $3 \mathrm{D}$ kinetics model of the Russian code NOSTRA can be used for comparison with a point kinetics model that is often used in accident analysis codes such as RELAP. In future the present analysis should be used for 3D model introduction in RELAP code. 
Russian Research Center "Kurchatov Institute"

Spatial Kinetics Calculations of MOX Fuelled Core. Variant 22

\section{REFERENCE}

1. K.L.Nikitin et al. Verification of the three-dimensional dynamic code NOSTRA. Problems of nuclear power installation safety. These of paper presented to the IX Seminar on reactor physics problems. Moscow, MEPhI, 1995.

2. In-core fuel management code package validation for WWERs. IAEATECDOC-847. November 1995. 
Comments from Oak Ridge National Laboratory staff on Spatial Kinetics Calculations of MOX Fuelled Core: Variant 22

1. The technical content of the report satisfies the milestone request from ORNL. When the MOX fuel assembly design is finalized and the final core loading pattern is selected, these calculations will be repeated for that design. At that time, it is expected that a final report for this effort will be generated, and we recommend that the Russian version as well as the English version of the final report be supplied to the United States so that the best possible translation from Russian to English is accomplished.

2. Chapter 2 is simply one big table with no text. If the report were to conform to ORNL standards, this table should either be combined with another chapter or additional text should be included referencing this table.

3. On page 15, the statement that the position of the regulating rod bank is $80 \%$ is interpreted to mean that the regulating rod bank is $80 \%$ inserted (see also comment on page 38 ).

4. On page 18, the MOX pin is stated to have a central hole diameter of $1.5 \mathrm{~mm}$. Previously, there has been no commitment from Russia as to the presence or lack of a central hole in MOX pins.

5. On pages 33 and 34, a definition of "corner" and "plane" on these figures is lacking.

6. On page 48, the position of the regulating rod bank is specified as being $70 \%$ from the core bottom. This is assumed to be a typical end-of-cycle value.

7. On page 57, the equation describing the boron concentration in the time interval $\tau_{1}<\mathrm{t}<\tau$ is not correct in that it does not account for the $\tau_{1}$ time offset. The correct equation probably should be:

$$
C(t)=\frac{3\left(1-\frac{\left(t-\tau_{1}\right)}{\left(\tau-\tau_{1}\right)}\right)}{3+\frac{\left(t-\tau_{1}\right)}{\left(\tau-\tau_{1}\right)}}
$$

8. For future reference, if revisions of these calculations are to be used for verification purposes, the detailed results of all parameters of interest should be given in tabular form in appendixes to allow for easier comparison of results. 


\section{ORNL/SUB/99-B99398V-6}

\section{INTERNAL DISTRIBUTION}

$\begin{aligned} 1 . & \text { R. J. Belles } \\ 2-6 . & \text { B. B. Bevard } \\ 7 . & \text { J. J. Carbajo } \\ 8 . & \text { M. D. DeHart } \\ 9 . & \text { F. C. Difilippo } \\ 10 . & \text { R. J. Ellis } \\ 11 . & \text { S. E. Fisher } \\ 12-16 . & \text { J. C. Gehin } \\ 17 . & \text { S. R. Greene } \\ 18 . & \text { R. Holdaway } \\ 19 . & \text { D. T. Ingersoll } \\ 20 . & \text { M. A. Kuliasha }\end{aligned}$

21. S. B. Ludwig

22. M. G. McGinnis

23. G. E. Michaels

24. D. L. Moses

25. W. P. Poore

26-30. R. T. Primm III

31. C. C. Southmayd

32. D. J. Spellman

33. G. L. Yoder, Jr.

34. Central Research Library

35-36. ORNL Laboratory Records (OSTI)

37. ORNL Laboratory Records (RC)

\section{EXTERNAL DISTRIBUTION}

38. M. L. Adams, Department of Nuclear Engineering, Texas A\&M University, Zachry 129, College Station, TX 77843

39. D. Alberstein, Los Alamos National Laboratory, MS-K551, P.O. Box 1663, Los Alamos, NM 87545

40. Dr. Kiyonori Aratani, Surplus Weapons Plutonium Disposition Group; International Cooperation and Nuclear Material Control Division; Japan Nuclear Cycle Development Institute; 4-49 Muramatsu, Tokai-mura, Naka-gun, Ibaraki-ken, Japan

41. J. Baker, Office of Fissile Materials Disposition, U.S. Department of Energy, MD-3, 1000 Independence Avenue SW, Washington, DC 20585

42. M. S. Chatterton, Office of Nuclear Reactor Regulation, MS O10B3, U.S. Nuclear Regulatory Commission, Washington, DC 20555-0001

43. K. Chidester, Los Alamos National Laboratory, MS-E502, P.O. Box 1663, Los Alamos, NM 87545

44. R. H. Clark, Duke/Cogema/Stone \& Webster, 400 South Tryon Street, WC-32G, P.O. Box 1004, Charlotte, NC 28202

45. W. Danker, U.S. Department of Energy, MD-3, 1000 Independence Avenue SW, Washington DC 20585

46. N. Fletcher, Office of Fissile Materials Disposition, U.S. Department of Energy, MD-3, 1000 Independence Avenue SW, Washington DC 20585

47. T. Gould, Lawrence Livermore National Laboratory, P.O. Box 808, MS-L186, Livermore, CA 94551

48. L. Holgate, Office of Fissile Materials Disposition, U.S. Department of Energy, MD-1/2, 1000 Independence Avenue SW, Washington DC 20585

49. L. Jardine, Lawrence Livermore National Laboratory, P.O. Box 808, MS-L166, Livermore, CA 94551 
50. Dr. Alexander Kalashnikov, Institute of Physics and Power Engineering, 1 Bondarenko Square, Obninsk, Kaluga Region, Russia 249020

51-55. D. E. Klein, Associate Vice Chancellor for Special Engineering Programs, The University of Texas System, 210 West Sixth Street, Austin, TX 78701

56. R. W. Lee, Office of Nuclear Reactor Regulation, MS O10B3, U.S. Nuclear Regulatory Commission, Washington, DC 20555-0001

57. S. Nesbit, Duke/Cogema/Stone \& Webster, 400 South Tryon Street, WC-32G, P.O. Box 1004, Charlotte, NC 28202

58. J. O. Nulton, Office of Fissile Materials Disposition, U.S. Department of Energy, MD-3, 1000 Independence Avenue SW, Washington, DC 20585

59. Nagao Ogawa; Director and General Manager; Plant Engineering Department; Nuclear Power Engineering Corporation; Shuwa-Kamiyacho Building, 2F; 3-13, 4-Chome Toranomon; Minato$\mathrm{Ku}$, Tokyo 105-0001, Japan

60. Dr. S. L. Passman, Booz-Allen \& Hamilton, 555 13th Street, NW, No. 480E, Washington, DC 20004

61-65. Dr. Alexander Pavlovitchev, Russian Research Center "Kurchatov Institute," Institute of Nuclear Reactors, VVER Division, VVER Physics Department, 123182, Kurchatov Square, 1, Moscow, Russia

66. K. L. Peddicord, Associate Vice Chancellor, Texas A\&M University, 120 Zachry, College Station, TX 77843-3133

67. W. D. Reece, Texas A\&M University, Department of Nuclear Engineering, Zachry 129, College Station, TX 77843-3133

68. P. T. Rhoads, Office of Fissile Materials Disposition, U.S. Department of Energy, MD-4, 1000 Independence Avenue SW, Washington, DC 20585

69. U. Shoop, Office of Nuclear Reactor Regulation, MS O10B3, United States Nuclear Regulatory Commission, Washington, DC 20555-0001

70. J. Thompson, Office of Fissile Materials Disposition, U.S. Department of Energy, MD-4, 1000 Independence Avenue SW, Washington, DC 20585

71. F. Trumble, Westinghouse Savannah River Company, Building 730R, Room 3402, WSRC, Aiken, SC 29808

72. Dr. Boris E. Volkov; Head of Division; EDO Gidropress, 21 Ordzhonikidze Street, Podolsk, Moscow District, Russia 142103 